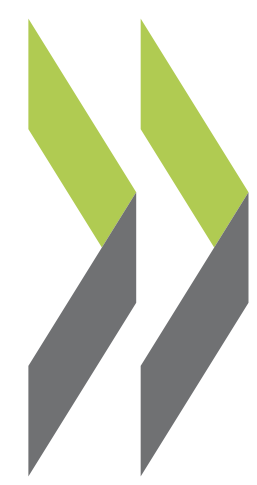

OECD Economics Department Working Papers No. 1610

Technological diffusion and managing

the associated economic Haruki Seitani, transitions in Ireland 


\section{ECONOMICS DEPARTMENT}

\section{TECHNOLOGICAL DIFFUSION AND MANAGING THE ASSOCIATED ECONOMIC} TRANSITIONS IN IRELAND

\section{ECONOMICS DEPARTMENT WORKING PAPERS No. 1610}

By Haruki Seitani and Ben Westmore

OECD Working Papers should not be reported as representing the official views of the OECD or of its member countries. The opinions expressed and arguments employed are those of the author(s).

Authorised for publication by Isabell Koske, Deputy Director, Country Studies Branch, Economics Department.

All Economics Department Working Papers are available at www.oecd.org/eco/workingpapers.

JT03463382 
OECD Working Papers should not be reported as representing the official views of the OECD or of its member countries. The opinions expressed and arguments employed are those of the author(s).

Working Papers describe preliminary results or research in progress by the author(s) and are published to stimulate discussion on a broad range of issues on which the OECD works.

Comments on Working Papers are welcomed, and may be sent to the Economics Department, OECD, 2 rue André-Pascal, 75775 Paris Cedex 16, France, or by e-mail to eco.contact@oecd.org.

All Economics Department Working Papers are available at www.oecd.org/eco/workingpapers.

This document and any map included herein are without prejudice to the status of or sovereignty over any territory, to the delimitation of international frontiers and boundaries and to the name of any territory, city or area.

The statistical data for Israel are supplied by and under the responsibility of the relevant Israeli authorities. The use of such data by the OECD is without prejudice to the status of the Golan Heights, East Jerusalem and Israeli settlements in the West Bank under the terms of international law.

๑) OECD (2020)

You can copy, download or print OECD content for your own use, and you can include excerpts from OECD publications, databases and multimedia products in your own documents, presentations, blogs, websites and teaching materials, provided that suitable acknowledgment of OECD as source and copyright owner is given. All requests for commercial use and translation rights should be submitted to rights@oecd.org. 


\section{ABSTRACT/RÉSUMÉ \\ Technological diffusion and managing the associated economic transitions in Ireland}

Technological change is transforming Ireland's economic structures, leading to new jobs and innovative products that benefit consumers. Adoption of new technologies by businesses has been high relative to many other OECD economies, but it has been uneven across industries and the impact on productivity growth in most firms has been modest so far. Policymakers must encourage further diffusion of new technologies through reforms that promote business dynamism, at the same time as supporting the accumulation of skills that help the productivity potential of such technologies be realised. Some workers who are displaced by technological change must be assisted in transitioning to new, higher productivity jobs through well-designed activation and training programmes. New jobs in the gig economy and changes in the geographic location of economic activity should also be accommodated, thereby adding to the flexibility of the Irish economy. Nevertheless, as technological progress causes business models and market structures to mutate, competition policies and data security measures will need to be revisited.

This Working Paper relates to the 2020 OECD Economic Survey of Ireland (http://www.oecd.org/economy/ireland-economic-snapshot/)

JEL classification: J24, J61, J63, J83, I28, I31, O33, O38, O52

Keywords: technological diffusion, future of work, competition policy, residential mobility, product market regulations, active labour market policies, gig economy, platform workers, productivity growth, skills, data security policies.

\section{Diffusion technologique et gestion des transitions économiques associées en Irlande}

Le changement technologique transforme les structures économiques de l'Irlande, créant de nouveaux emplois et des produits innovants profitant aux consommateurs. L'adoption de nouvelles technologies par les entreprises a été élevée par rapport à de nombreuses autres économies de l'OCDE, mais inégale d'une industrie à l'autre et l'impact sur la croissance de la productivité dans la plupart des entreprises a été jusqu'ici modeste. Les décideurs doivent encourager une plus grande diffusion des nouvelles technologies grâce à des réformes favorisant le dynamisme des entreprises, tout en soutenant l'accumulation de compétences contribuant à la réalisation du potentiel de productivité de ces technologies. Certains travailleurs déplacés par les changements technologiques doivent être aidés à passer à de nouveaux emplois à productivité plus élevée grâce à des programmes d'activation et de formation bien conçus. Les nouveaux emplois à contrats courts et des changements dans la localisation de l'activité économique devraient également être pris en compte, afin de renforçer la flexibilité de l'économie irlandaise. Néanmoins, comme le progrès technologique entraîne une mutation des modèles de gestion et des structures de marché, les politiques de concurrence et les mesures de sécurité des données devront être revues.

Ce Document de travail a trait à l'Étude économique de l'OCDE de l'Irlande, 2020 (http://www.oecd.org/fr/economie//rlande-en-un-coup-d-oeil/).

Classification JEL : J24, J61, J63, J83, I28, I31, O33, O38, O52

Mots clés : Diffusion technologique, avenir du travail, politique de la concurrence, mobilité résidentielle, réglementation du marché des produits, politiques actives du marché du travail, économie des contrats courts, travailleurs de plateformes de support en ligne, croissance de la productivité, compétences, politiques de sécurité des données. 


\section{Table of contents}

\section{Technological diffusion and managing the associated economic transitions in Ireland}

Trends in technological disruption

Further technological adoption by businesses can boost productivity and incomes

Skill needs are evolving as new technologies are embraced

The nature of some jobs will change with greater technological diffusion

Online platforms will allow more workers to participate in the gig economy

Greater residential mobility is needed as the geography of growth evolves

Competition and digital security policies need to be revisited amid ongoing technological progress

Tax policy settings also need updating

References

\section{FIGURES}

Figure 1. The economy has been through significant structural change

Figure 2. Services and knowledge-intensive sectors have gained prominence $\quad 7$

Figure 3. Dublin has experienced particularly fast economic growth $\quad 8$

Figure 4. Intangible capital accumulation has risen notably 10

Figure 5. Technological adoption has risen, but there are large differences across industries 11

Figure 6. Technological adoption varies greatly by firm size 13

Figure 7. Engagement with citizens through government websites is relatively rare 13

Figure 8. Labour productivity growth in Ireland has been driven by capital inputs $\quad 15$

Figure 9. The productivity gap between foreign and Irish-owned firms has widened 16

Figure 10. Intangible investments have not always been accompanied by higher productivity 16

Figure 11. Investments in software and economic competencies are low in Ireland 17

Figure 12. Investment in economic competencies is associated with rising multifactor productivity 18

$\begin{array}{ll}\text { Figure 13. Costs are high in the Irish legal services sector } & 19\end{array}$

Figure 14. Labour productivity has been particularly weak in sectors with low firm entry and exit 20

Figure 15. Firm entry and exit rates are lower in Ireland than in many other countries 20

Figure 16. Complex regulatory procedures and the licensing and permission process impede business activity 21

Figure 17. Skills of Irish adults are lower than indicated by formal qualifications 24

Figure 18. Skill shortages in Ireland stand out $\quad 25$

Figure 19. The labour market has been tightening $\quad 25$

Figure 20. Greater intangible capital investment necessitates re-skilling $\quad 26$

Figure 21. Sectors with high intangible investment face difficulties in filling job vacancies 27

Figure 22. Performance indicators for the adult learning system are mixed 28

Figure 23. Young and older workers must be better encouraged to participate in training 29

Figure 24. Smaller firms tend to train less than larger firms $\quad 30$

Figure 25. Jobs growth has been particularly strong for those with high skill levels 32

Figure 26. The pool of jobseekers has declined more rapidly than resources devoted to activation $\quad 35$

Figure 27. The share of self-employment in Ireland is around the OECD average $\quad 37$

Figure 28. The Dublin dwelling price premium has been rising 40

Figure 29. Dubliners have been moving to contiguous counties 41 
Figure 30. Many now face a long commute

Figure 31. Dwelling prices reflect supply conditions $\quad 42$

Figure 32. Regional inequality has been rising $\quad 44$

Figure 33. Local governments have little spending power $\quad 45$

Figure 34. The firm entry rate has been weaker in digitally-intensive sectors 46

Figure 35. Corporate mergers and acquisitions have become more common 47

\section{TABLES}

Table 1. Sectoral information technology investment across countries 12

Table 2. Obstacles to participation in education and training 30

Table 3. Estimation results $\quad 33$ 


\title{
Technological diffusion and managing the associated economic transitions in Ireland
}

\author{
By Haruki Seitani and Ben Westmore ${ }^{1}$
}

Structural economic change has been a persistent feature of Ireland's past three decades, more so than in most OECD countries (Figure 1). The ability of the economy to adapt to new demographic, economic and technological trends has been evidenced by its impressive performance: since the mid-1990s, the average real wage has increased by over $50 \%$ in Ireland, compared with around $30 \%$ in the United States or the average OECD country.

The share of employment in the services sector has increased markedly over the past decade (Figure 2, Panel A), reflecting the contraction of the construction industry following the 2008-13 property market downturn and the continued trend decline in manufacturing. At the same time, the technological intensity of the economy has been rising steadily: the employment share of knowledge-intensive services and high-tech manufacturing has increased and dwarfs the European Union average (Figure 2, Panel B). Ireland now has the highest proportion of high-tech goods exports of any European economy. These developments have contributed to changes in the geographic distribution of economic activity, with Dublin experiencing much faster growth than many other parts of Ireland since 2010 (Figure 3).

\footnotetext{
${ }^{1}$ Haruki Seitani and Ben Westmore are members of the OECD Economics Department. The authors would like to thank Vincent Koen, Yosuke Jin, Alvaro Pereira, Isabel Koske and Patrick Lenain (from the OECD Economics Department), James Mancini (OECD Directorate for Financial and Enterprise Affairs), Luca Marcolin, Stijn Broecke, Marguerite Lane, Marissa Plouin and Willem Adema (OECD Directorate for Employment, Labour and Social Affairs), Dirk Pilat (OECD Directorate for Science, Technology and Innovation), Bert Brys and Anna Milanez (OECD Centre for Tax Policy and Administration), for useful comments and suggestions. The paper has also benefitted from comments by Irish officials and by members of the OECD Economic and Development Review Committee. Special thanks go to Ronan Lyons (Trinity College Dublin) for inputs to the analysis, Lutécia Daniel (OECD Economics Department) for statistical assistance, and Sisse Nielsen and Michelle Ortiz (Economics Department) for editorial assistance.
} 
Figure 1. The economy has been through significant structural change

Index of structural change

Index

12

10

8

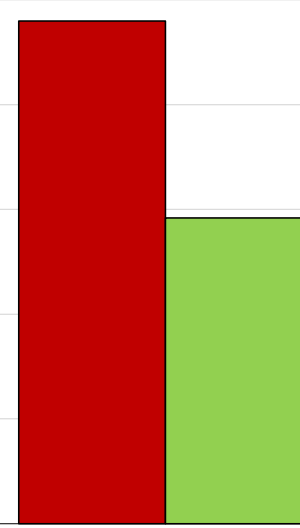

$1995-2002$

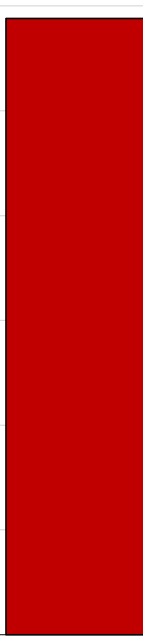

2003-2010
- Ireland $\square \mathrm{OECD}$

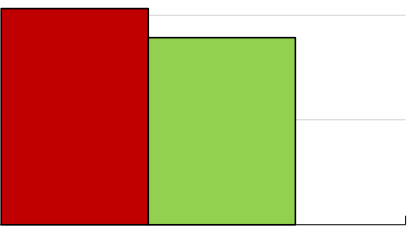

$2011-2018$

Note: The Lilien Index is used to examine the extent of structural change (Lilien, 1982). The index measures employment dispersion by taking a weighted standard deviation of sectoral employment growth relative to aggregate employment growth over the given time horizon. The OECD aggregate is an average across 24 OECD countries for which comparable data are available.

Source: OECD.

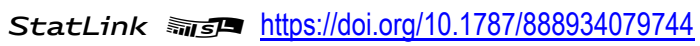

Figure 2. Services and knowledge-intensive sectors have gained prominence

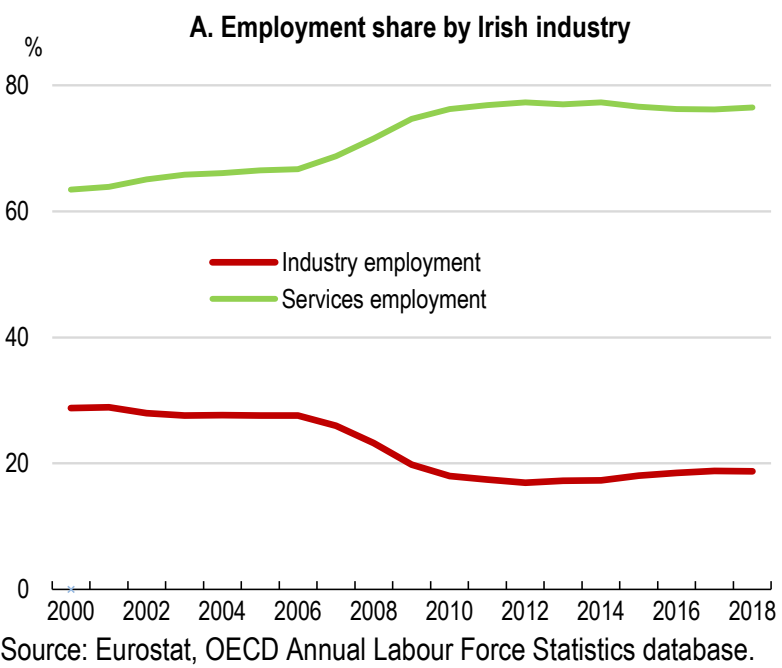

\section{B. Employment share of high-tech manufacturing and knowledge-intensive service sectors}

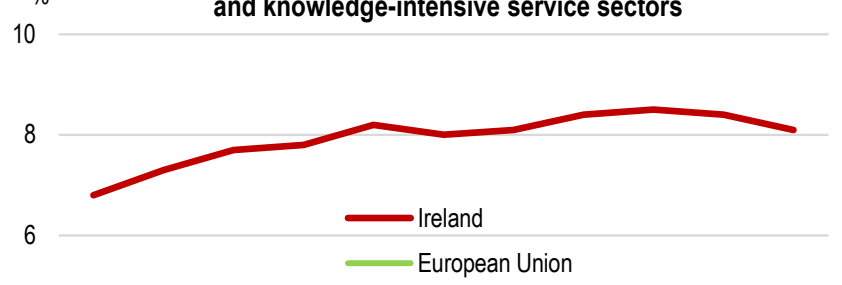

4

2

$\begin{array}{llllllllllll}0 & & & & & & & & & & & \\ 2008 & 2009 & 2010 & 2011 & 2012 & 2013 & 2014 & 2015 & 2016 & 2017 & 2018\end{array}$ Source: Eurostat, OECD Annual Labour Force Statistics database.

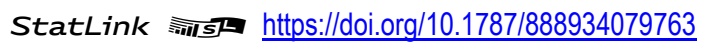




\section{Figure 3. Dublin has experienced particularly fast economic growth}

Percentage change in estimated gross value added, 2010-17

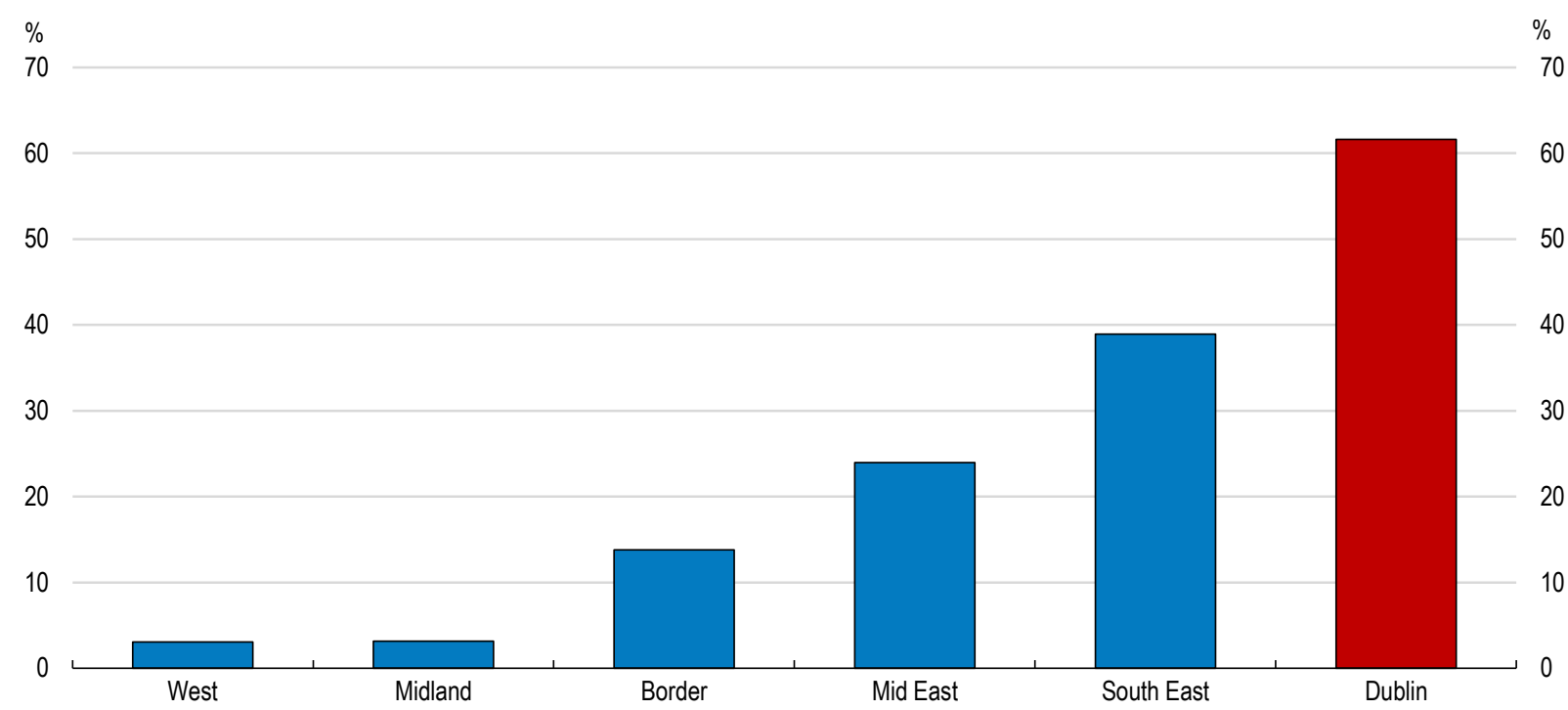

Note: The distortion to gross value added statistics in 2015 from the activities of some multinationals is addressed by interpolating between 2014 and 2016 based on the historical relationship between regional employment data and regional gross value added.

Source: Central Statistics Office, OECD calculations.

These trends have coincided with increased technological diffusion in many parts of the Irish economy. The OECD Going Digital Project highlighted how digital technologies, in particular, are growing in their importance (OECD, 2019a). Technological progress is at the forefront of economic development and is overwhelmingly positive for aggregate social welfare. New technologies are transforming existing structures, influencing the way that producers create and interact with one another and with customers. Novel areas of economic activity are opening up thanks to the emergence of technologies, creating jobs. There are also benefits to consumers, with technological advances providing access to new, innovative and cheaper products. The 2018 OECD Ireland Economic Survey focused on productivity growth in the business sector as a fundamental ongoing challenge for Irish enterprises. Indeed, further technological diffusion, and the complementary organisational changes needed to fully realise the benefits, must continue to be promoted to foster more efficient production processes and raise competitiveness.

While embracing new technologies is fundamental to support future Irish living standards, the potential for unintended adverse consequences in certain parts of the economy must not be ignored. Public policy settings may need to be revisited in order to ensure that any undesirable effects of a quickening pace of technological diffusion are mitigated. More broadly, policy measures will need to evolve to recognise the new structure of the economy and the associated market failures that could arise. The authorities recently released Future Jobs Ireland, which notes many of the important opportunities and challenges associated with future technological diffusion (Government of Ireland, 2019a). The task now is to develop tangible policy recommendations in response.

\section{Trends in technological disruption}

The expanding role of technology in the Irish economy has been reflected in the rising share of intangible capital in the total stock of fixed assets (Figure 4, Panel A), from $3 \%$ in 2000 to over $15 \%$ by 2018 . This coincided with growing innovation activity, with the number of new Irish patents per capita increasing over the past decade and being above the average across OECD countries. 
Ireland performs relatively well in innovation outputs relating to information and communications technology (ICT) and biotechnologies. However, the country lags in environmentally-related inventions, which is a concern given the pressing global need to combat environmental pressures and the fact that the market for such new technologies is likely to expand over the coming years. Furthermore, as outlined in the 2018 OECD Economic Survey of Ireland, the vast majority of innovation activities are undertaken in foreign-owned enterprises: research personnel account for less than $1 \%$ of the workforce in locally-owned firms. The forthcoming OECD FDI Qualities and Impacts in Ireland shows that $80 \%$ of all patents granted in Ireland are filed by foreign-owned firms (OECD, 2020a). As such, of primary importance for most Irish businesses is the extent to which new innovations are successfully integrated into their operations.

Irish businesses surpass their peers in the adoption of some new technologies. In 2019, the Digital Economy and Society Index ranked Ireland as the leading country in the EU for the integration of digital technology. The proportion of Irish businesses utilising cloud computing, social media and big data exceeds the OECD average (Figure 4 Panel B). Nevertheless, less than one third of Irish firms use enterprise resource planning or customer relationship management systems to raise operational efficiency and sales. Recent OECD cross-country empirical analysis suggests that a 10 percentage point increase in the adoption of either of these technologies is associated with a $4-71 / 2 \%$ increase in the level of multifactor productivity after five years (Gal et al., 2019). While robotics is not widely used in Ireland (Figure 4, Panel C), this partly reflects a lack of comparative advantage in those industries that use robots most intensively (e.g. car manufacturing). As technological adoption gathers pace, the authorities have been undertaking various initiatives to ensure that the environmental impact of new technologies and production processes are taken into account by firms (Box 1).

As in other OECD countries, technological adoption has been uneven across Irish industries. Intangible capital now accounts for a much higher share of the net capital stock than it did in the mid-1990s in professional services, ICT, manufacturing, mining, education and wholesale and retail trade (Figure 5, Panel A). In both professional services and ICT, the intangible capital share has steadily increased over the period, accounting for over two thirds of the net capital stock by 2017. Across industries, the stock of computer software has risen seven-fold in real terms since 1995. Nonetheless, the intensity of adoption varies. For example, over $90 \%$ of Irish businesses in the telecommunications industry made use of cloud computing in 2018 , while less than one third of businesses in the retail trade sector did so. 
Figure 4. Intangible capital accumulation has risen notably

\section{A. Intangible fixed asset net capital stock, $\%$ of fixed assets}

18

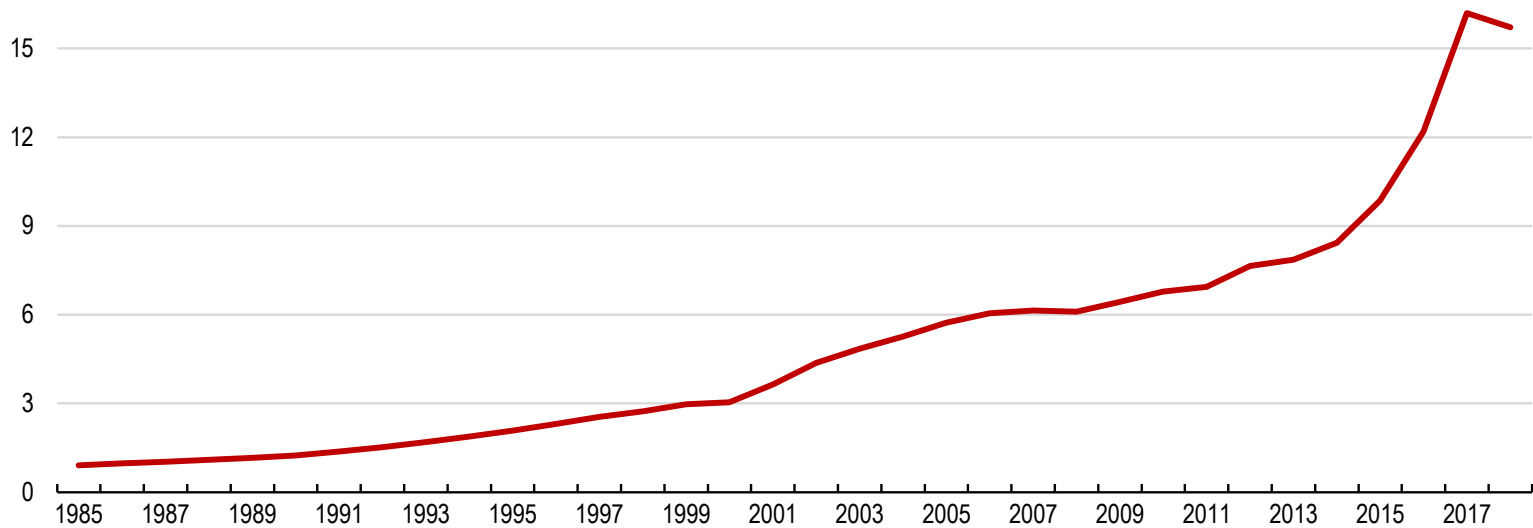

B. ICT usage by business (\% of enterprises), 2018 or latest available

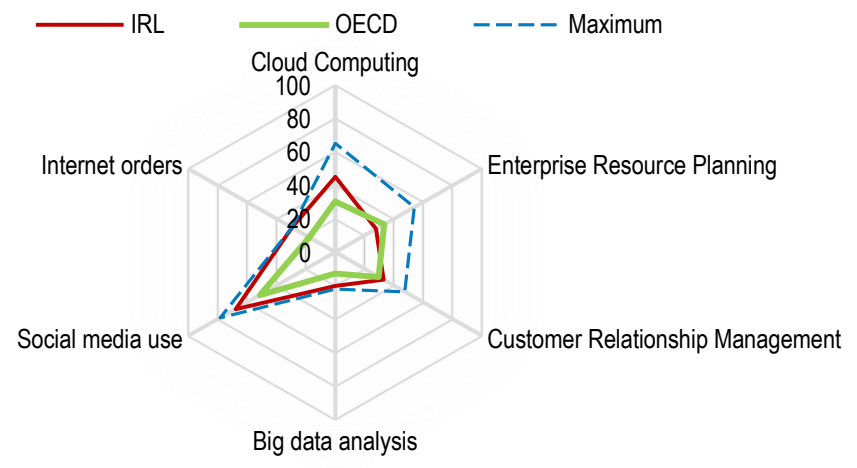

Per thousand workers

C. Number of robots, 2017

30

25

15

10

5

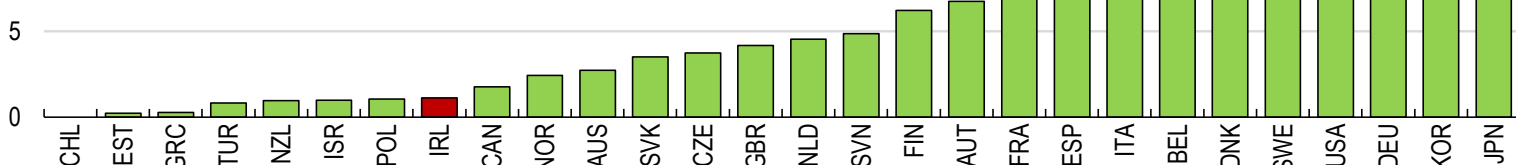

Note: Panel A includes all NACE Rev. 2 sectors other than administrative and support service activities. The two main components of intangible capital are computer software and research and development. In Panel B, "OECD" is the average across all OECD countries for which data are available. In this figure, data for enterprise resource planning, customer relationship management and social media use relate to 2017, while all other series are for 2018. In Panel C, robot use data is measured as the number of robots purchased by a given country. The robot stock is constructed by taking the initial stock starting value, then adding to it the purchases of robots from subsequent years with a $10 \%$ annual depreciation rate. The sample covers the manufacturing and utilities sectors only.

Source: Central Statistics Office, OECD ICT Access and Usage by Businesses database, International Federation of Robotics, OECD calculations. 
Figure 5. Technological adoption has risen, but there are large differences across industries

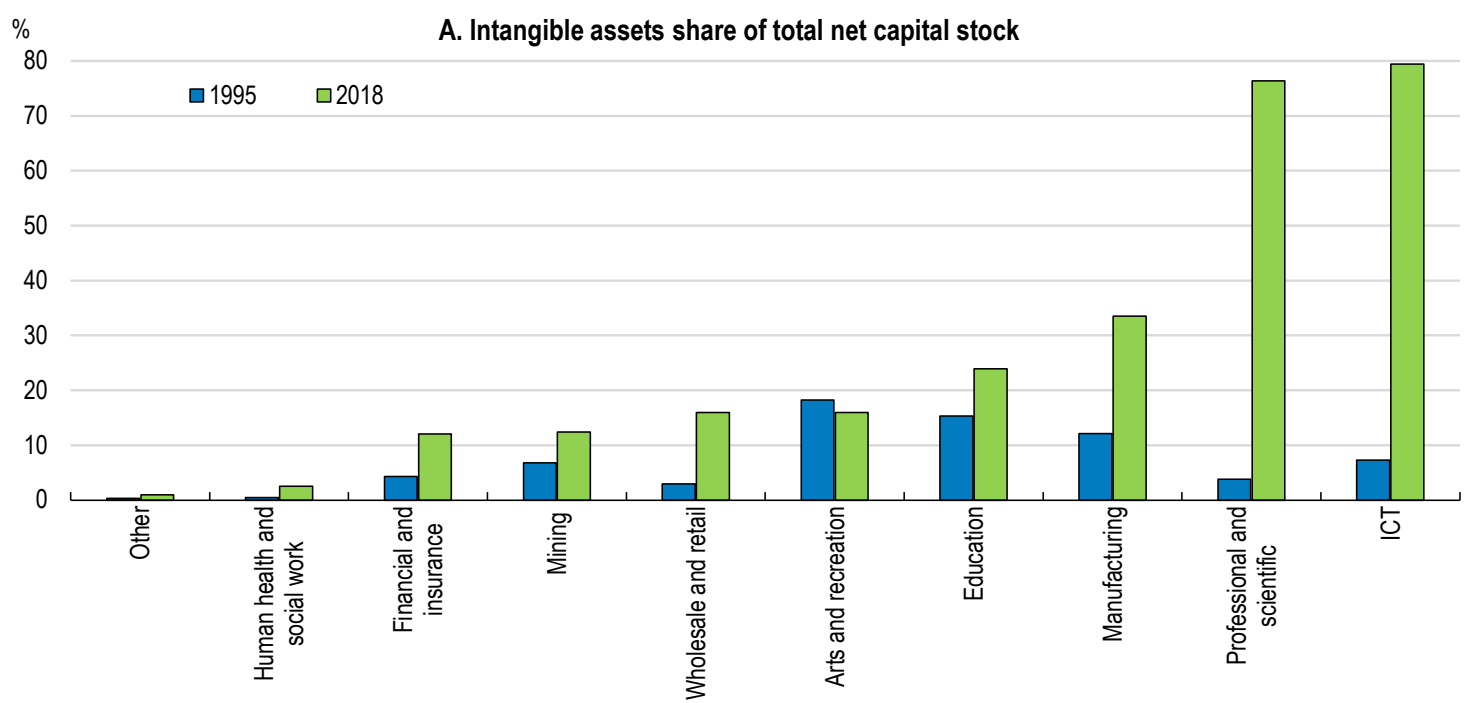

B. Adoption of selected digital technologies (\% of Irish enterprises by industry)

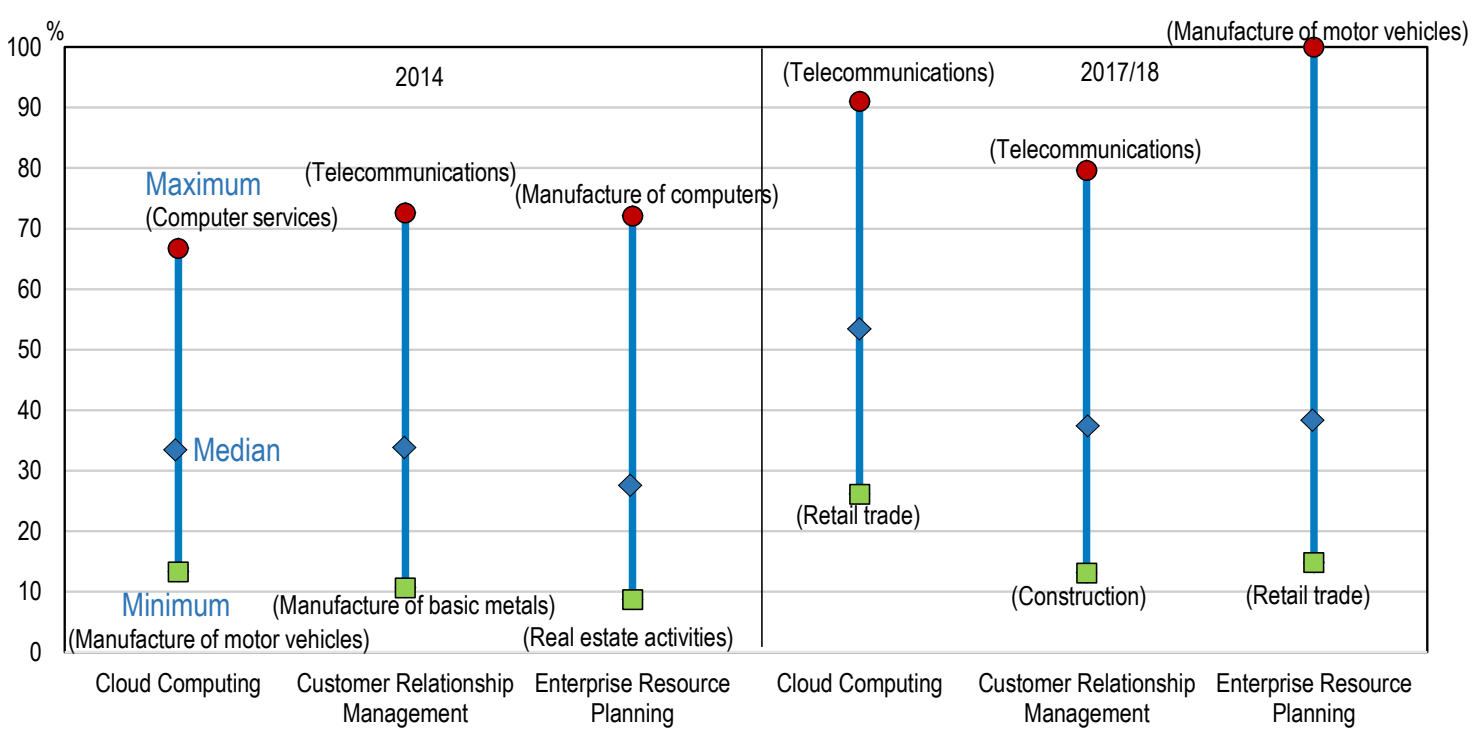

Note: In Panel A, the 2018 value for the manufacturing sector corresponds to the most recent available number, which is for 2015. The "Other" category is a simple average across all other sectors. In Panel B, the vertical line represents the range across two-digit NACE industries of digital adoption (\% of firms) of the selected technologies. On the right-hand-side panel, the data for enterprise resource planning and customer relationship management relate to 2017, while the data for Cloud Computing relate to 2018.

Source: CSO, Eurostat, OECD calculations.

StatLink त्ञात्र https://doi.org/10.1787/888934079820

Cross-country comparison suggests that there has been especially strong ICT uptake in Ireland's education, utilities and wholesale and retail trade sectors over the past few decades (Table 1). In contrast, scope for higher ICT spending intensity exists in Ireland's agriculture, construction, transport, accommodation and food, human health and arts and entertainment industries.

The degree of technological adoption varies with business size, as in many other OECD economies. While over $60 \%$ of large firms purchased cloud computing services in 2018 , only around $40 \%$ of small Irish businesses did so (Figure 6). This may reflect the vast gap in the proportion of large and small firms with access to fast broadband connections. Insofar as this is due to poor broadband availability for some of these businesses, the National Broadband Plan that aims to provide all people and businesses with access 
to high-speed broadband should be beneficial. Compared to their peers in the Netherlands, Sweden and Denmark, small Irish businesses are indeed less likely to have access to fast broadband connections.

The efficiency of the public sector can also benefit from using new technologies. As consumers and businesses increasingly become familiar with new digital forms of communication, governments can digitise existing processes and offer public services online. Furthermore, more data combined with smart analysis should allow governments to offer more efficient public services and new innovations that improve citizens' wellbeing. Unlike in almost all other Irish industries, the intangible capital share of fixed assets in public administration has declined since the mid-1990s. Indeed, it appears that government could better leverage new technological opportunities, not least in engaging with Irish citizens (Figure 7). In this spirit, there have been plans to introduce the "Digital Postbox" system that has been successfully implemented in many other OECD countries. This would allow citizens to receive government correspondence in digital form through a secure electronic mailbox.

\section{Table 1. Sectoral information technology investment across countries}

Average ICT equipment investment as a share of total machinery and equipment investment (\%), 2000-2017

\begin{tabular}{l|c|c|c|c|c}
\hline & IRL & AUT & NZL & DNK & NLD \\
\hline Agriculture and forestry & 0.5 & 1.3 & 5.8 & 10.0 & 2.0 \\
\hline Mining & 3.8 & 0.7 & 7.6 & 21.8 & 1.7 \\
\hline Manufacturing & 6.7 & 6.5 & 11.0 & 14.6 & 5.3 \\
\hline Electricity, gas, steam & 18.8 & 17.3 & 17.5 & 7.0 & 3.0 \\
\hline Water supply and waste & 10.8 & 6.0 & $\mathrm{~N} / \mathrm{A}$ & 9.8 & 4.5 \\
\hline Construction & 4.2 & 7.9 & 7.1 & 18.9 & 8.1 \\
\hline Wholesale and retail trade & 27.1 & 16.8 & 17.2 & 18.8 & 14.7 \\
\hline Transport & 1.3 & 7.9 & 11.0 & 5.1 & 6.5 \\
\hline Accommodation and food & 7.7 & 11.9 & 9.9 & 17.3 & 10.0 \\
\hline ICT & 76.3 & 84.8 & 83.3 & 52.4 & 41.0 \\
\hline Financial and insurance & 34.1 & 13.0 & 35.7 & 49.1 & 62.3 \\
\hline Real estate & 40.4 & 13.5 & 17.7 & 50.8 & N/A \\
\hline Professional \& scientific & 43.6 & 35.9 & 46.8 & 34.9 & 36.8 \\
\hline Administrative and support & 15.3 & 8.7 & 36.6 & 12.6 & 3.9 \\
\hline Public administration & 24.3 & 17.7 & 16.0 & 10.7 & 31.2 \\
\hline Education & 43.3 & 30.1 & 36.8 & 41.7 & 26.0 \\
\hline Human health & 9.4 & 59.7 & 78.7 & 22.8 & 33.5 \\
\hline Arts and entertainment & 18.6 & 38.0 & 39.8 & 29.5 & 45.7 \\
\hline Other services & 9.9 & 24.2 & 31.4 & 51.8 & 9.8 \\
\hline
\end{tabular}

Note: Cells are highlighted in orange where the ICT share of investment is at the bottom of the distribution across the countries presented. Cells are highlighted in blue where Ireland is at the top of the distribution for ICT investment.

Source: OECD. 
Figure 6. Technological adoption varies greatly by firm size

Percentage of businesses using the given technology, 2018

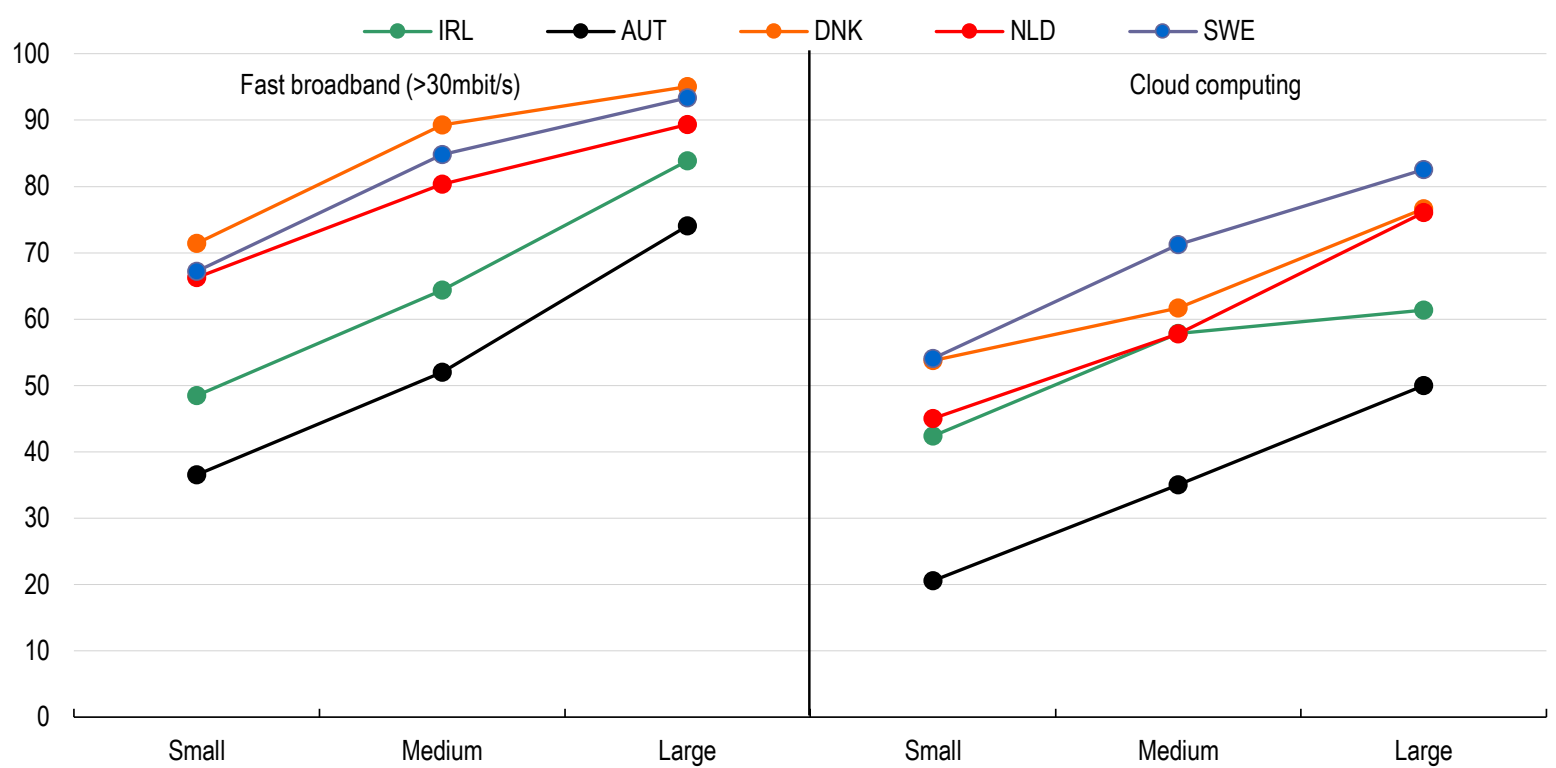

Note: A "small" firm has 10-49 employees, a "medium" firm 50-249 employees and a "large" firm over 250 employees. Bourke and Roper (2019) report that the proportion of "micro" businesses (1-9 employees) adopting cloud computing is in line with that of small businesses in 2018. Source: OECD ICT Access and Usage by Businesses database.

StatLink 제s https://doi.org/10.1787/888934079839

Figure 7. Engagement with citizens through government websites is relatively rare

Use of digital government services by individuals, percentage of individuals aged 16-74, 2018

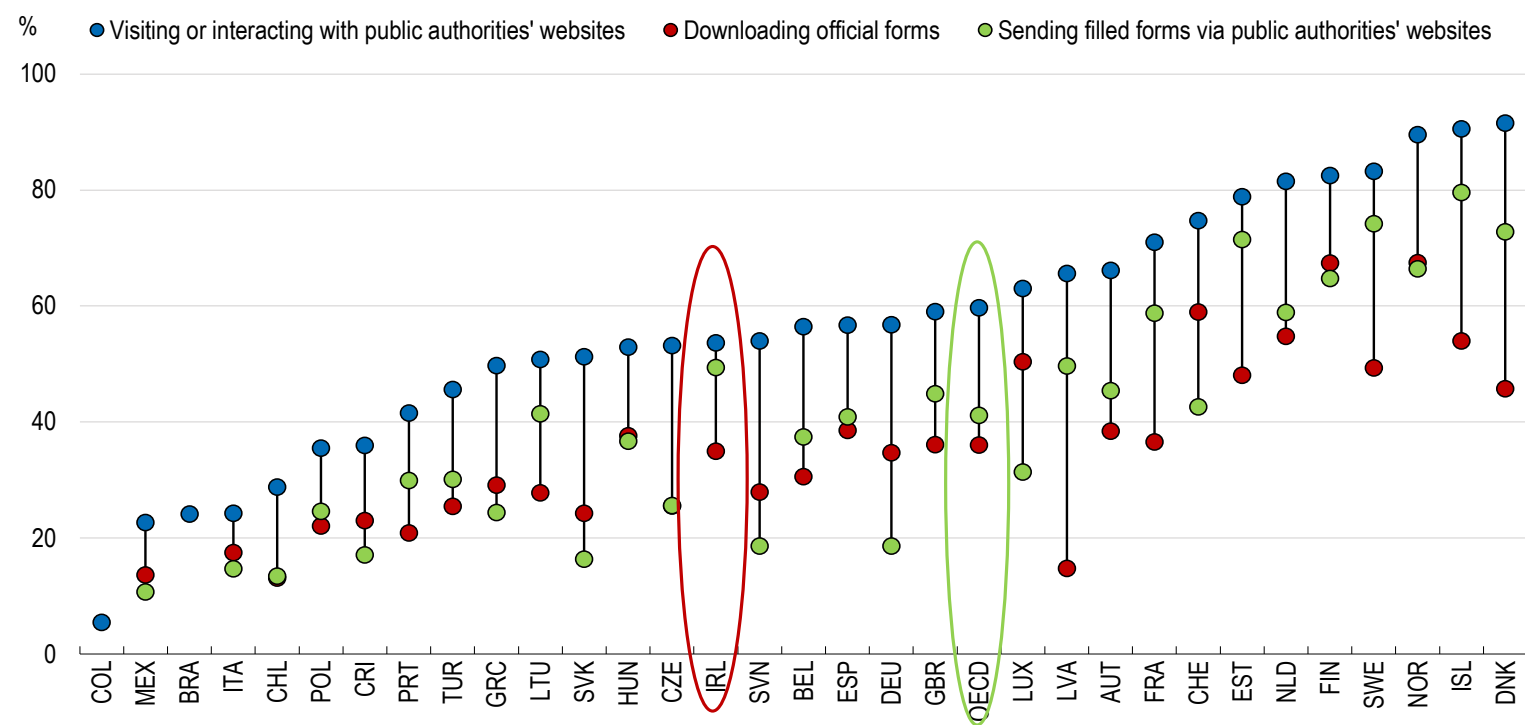

Source: OECD ICT Access and Usage by Households and Individuals database.

StatLink त्गाड़ https://doi.org/10.1787/888934079858

In sum, the use of technology has expanded considerably within the Irish economy. Nevertheless, the extent of technological adoption has varied across technologies, sectors and types of firms. Looking 
forward, there would appear to be substantial scope for more adoption of new technologies that promote efficiency and, ultimately, the wellbeing of the population.

\section{Box 1. Encouraging green technologies in the Irish business sector}

As technological change increasingly prompts Irish businesses to invest in new capital, the environmental footprint of additions to the capital stock must be considered. As some benefits from using green technologies will accrue to the general public through lower pollution, waste and greenhouse gas emissions, there is a role for public policy in encouraging the uptake of green technologies by firms. Acknowledging this, transitioning to a low carbon economy is one of the five key pillars of Future Jobs Ireland.

Ireland has introduced several initiatives to encourage more environmentally-friendly production techniques against the backdrop of the Climate Action Plan. These include:

- Green Start - For SMEs, aimed at increasing the level of environmental awareness relating to regulatory compliance and the development of basic environmental management capabilities.

- Green Plus - Financial support for undertaking an assignment designed to assist company managers in developing a high level of environmental management capabilities, improving environmental efficiency and sustainability.

- Environmental Aid Programme - Designed to assist companies to implement major renewable energy or energy efficiency initiatives.

- Energy Efficiency Grants and Supports - Typically up to $30 \%$ grants for energy efficiency investments.

- The Green Business Initiative - Run by the Environmental Protection Agency, the initiative includes self-help web tools and site visit support to assist businesses in improving resource efficiency.

\section{Further technological adoption by businesses can boost productivity and incomes}

Multifactor productivity has stalled in Ireland since the early 2000s (Figure 8, Panel A). Although labour productivity is the highest among OECD countries, this rests on investment in capital. Compared with the 1985-1995 period, the subsequent two decades saw strong growth in the accumulation of tangible capital along with ICT and intangible assets (Figure 8, Panel B), resulting in a slump in capital productivity (Figure 8, Panel C).

A notable feature of the Irish economy is the large productivity gap between foreign-owned multinational companies and Irish-owned firms (Figure 9). The forthcoming OECD FDI Qualities and Impacts in Ireland publication indicates that the gap exists across all sectors and regions (OECD, 2020a). This partly reflects lower capital investment by local firms. However, there is also a notable difference in multifactor productivity between these two groups. Based on firm-level analysis, the 2018 OECD Ireland Economic Survey highlighted a positive and widening gap in multifactor productivity between foreign-owned and Irishowned companies in most sectors of the economy. 
Figure 8. Labour productivity growth in Ireland has been driven by capital inputs

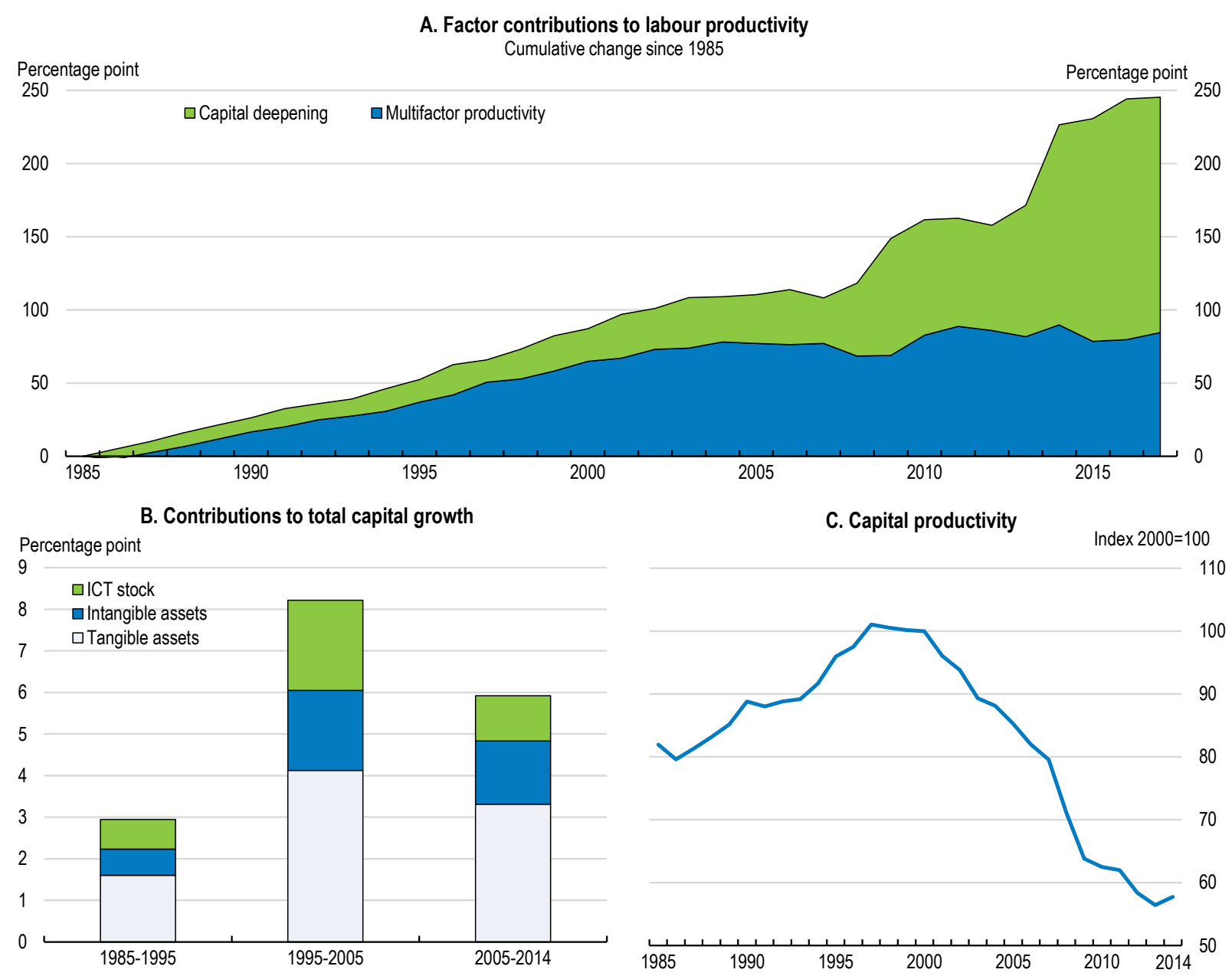

Note: Data are from the OECD Productivity Statistics except those of Ireland over 2015-2017 in Panel A, which are calculated based on the Central Statistics Office. In Panel A, GDP per hour worked in terms of US dollar measured by constant Purchasing Power Parity (PPP) in 2010. In Panel C, GDP per unit of capital service in terms of US dollar measured by constant PPP in 2010.

Source: OECD Productivity Statistics database, CSO, OECD calculations.

StatLink 게에 https://doi.org/10.1787/888934079877

While there is substantial scope for further investment in new technologies in Ireland, especially in smaller Irish-owned enterprises, this will not be sufficient. Indeed, there has been no discernible relationship between intangible capital investment and industry productivity (Figure 10). Sustainable productivity gains can only be achieved if these technologies are complemented by the right skills and organisational capital (Box 2). Policymakers will also need to ensure that both investments in new technologies and the growth of enterprises that successfully integrate them are not constrained by regulatory impediments or market failures. 
16 | ECO/WKP(2020)18

Figure 9. The productivity gap between foreign and Irish-owned firms has widened

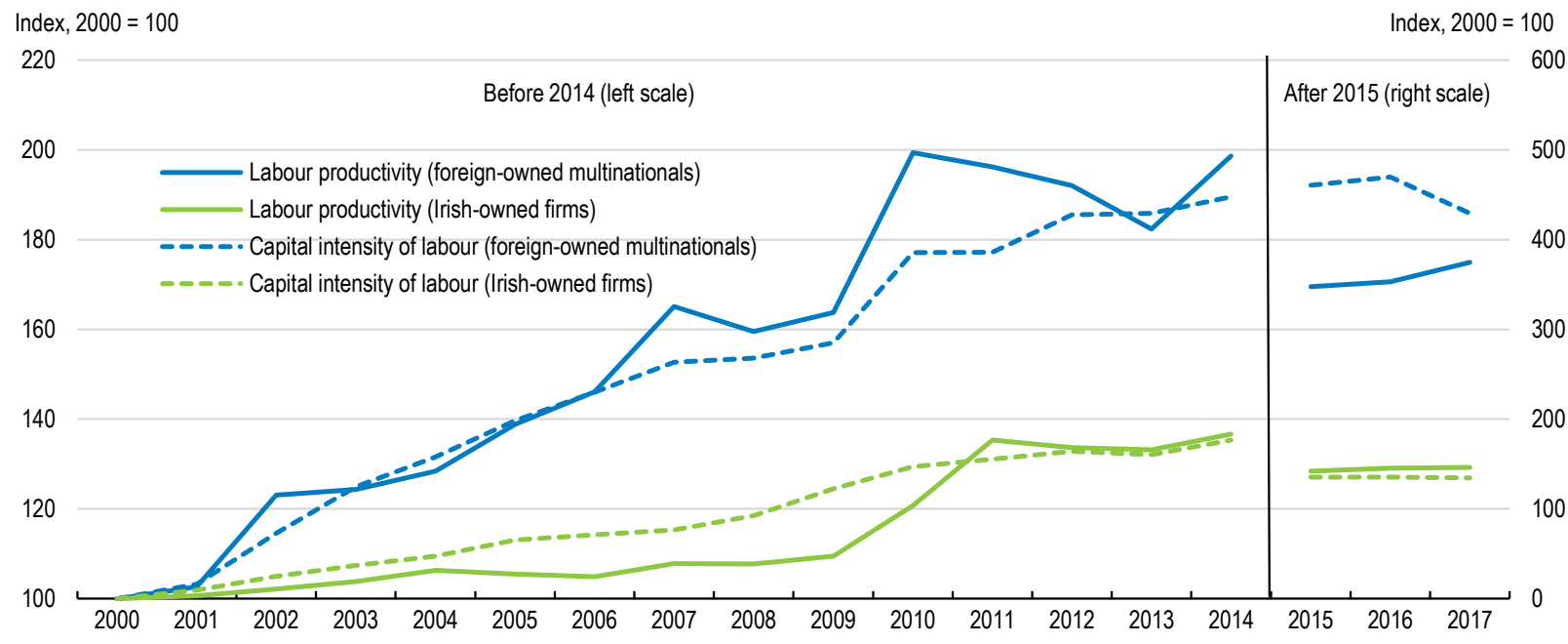

Source: CSO.

StatLink ज्ञाs https://doi.org/10.1787/888934079896

Figure 10. Intangible investments have not always been accompanied by higher productivity

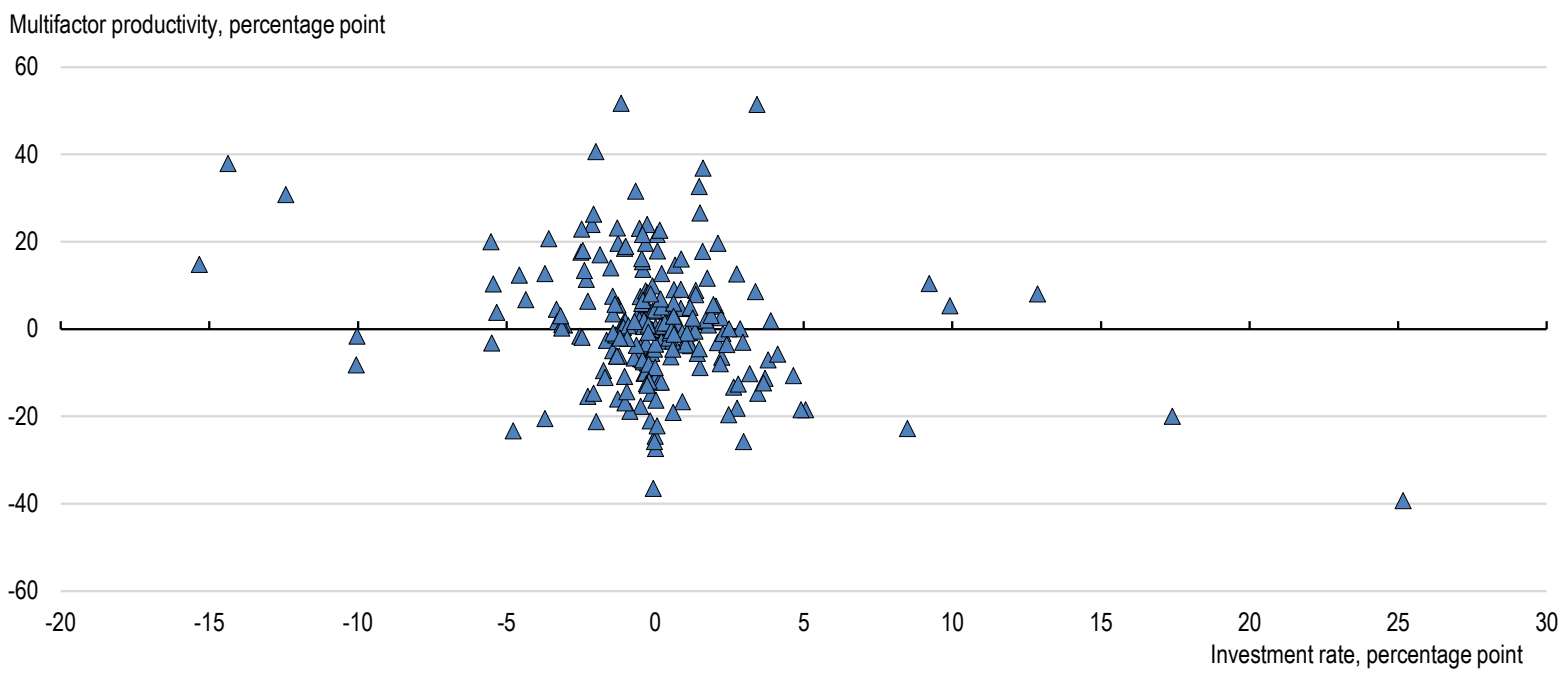

Note: Investment rate on the horizontal axis is measured by investment in innovative property and software as a share of value-added. Data for 2015 are excluded for the manufacturing sector and professional, administrative and support services, as they are disrupted by sharp increases of the investment rates of $37.3 \%$ and $9.1 \%$ respectively. Source: CSO, INTAN-Invest database.

StatLink ज्ञाs https://doi.org/10.1787/888934079915 


\section{Box 2. The importance of economic competencies to Irish productivity growth}

A study by the European Investment Bank provides a complete dataset of intangible investment in 19 European countries and the United States, covering a range of knowledge-based assets that national accounts do not include (Corrado et al., 2016). It highlights that the intangible investment rate in Ireland ranks second among the participating countries, but this largely reflects the accumulation of intellectual property, which can be heavily influenced by one-off cross-border transfers by multinationals. Investments in software and economic competencies are relatively low (Figure 11).

\section{Figure 11. Investments in software and economic competencies are low in Ireland}

As a share of gross value added of all industry, average over 2010-2016

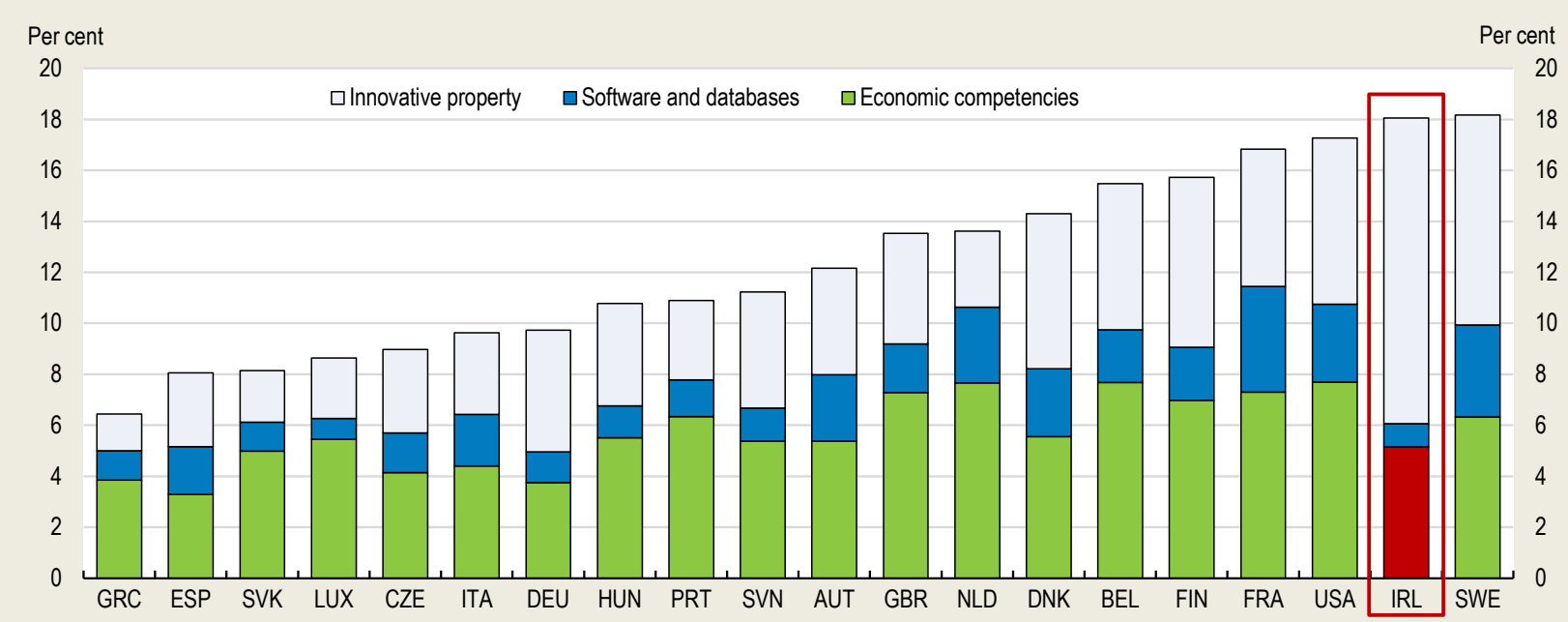

Note: Innovative property refers to investment in a range of knowledge assets that may have intellectual property protection, including R\&D, mineral exploration rights, designs, artistic originals, and new product development costs in financial industry. Economic competencies refers to investment in a range of knowledge assets that may have no intellectual property rights, including corporate branding, organisational and human capital management innovations.

Source: INTAN-invest database.

StatLink त्गाज्ञ https://doi.org/10.1787/888934079934

Investment in economic competencies includes investment in organisational and human resource management innovations, designs and artistic originals, and corporate branding. Sluggish multifactor productivity growth in Ireland may be related to the relatively low investment in economic competencies for two reasons. First, to the extent that those knowledge-based assets are not captured by the national accounts, their returns are embodied in multifactor productivity, which is measured as a residual of output that cannot be explained by capital and labour inputs. Second, organisational capital, managerial competency and workers' skills can play an important role in translating new technologies into productivity gains by adapting the technology and reorganising workplaces to optimise their impact (Gal et al., 2019). An analysis of a panel of Irish industries finds that an increase in the investment rate in economic competencies is associated with a significant rise of multifactor productivity in subsequent years (Figure 12). 
Figure 12. Investment in economic competencies is associated with rising multifactor productivity

Cumulative response of multifactor productivity to a one percentage point increase of the investment rate

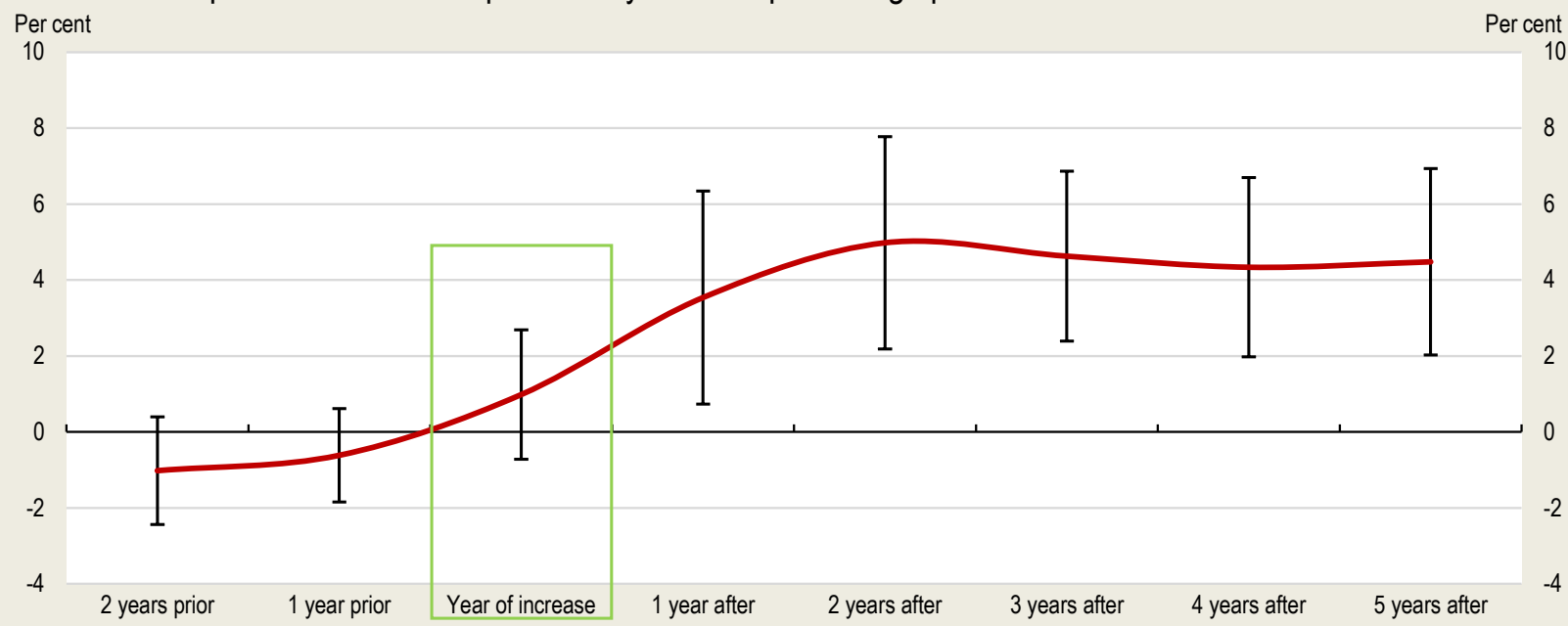

Note: Estimated from data on 14 NACE Rev.2 sectors over the period 2000-2017. Vertical lines show two-standard errors of the estimates. Following Duval and Furceri (2011), estimates were obtained by linear projections of cumulative changes of multifactor productivity on a change in the investment rate in economic competencies, which are specific to forecast points ranging between 2 years prior to and 5 years following the change. Time-fixed industry dummies are involved in each projection equation to take into account the heterogeneity in trend productivity growth across the sectors. Dummies for the manufacturing sector in 2015 and thereafter are also included to control for the GDP jump in that year. Regressions are weighted according to value-added by industry. Standard errors are Newey-West heteroskedasticity-robust estimates. Source: CSO, INTAN-Invest database, OECD calculations.

StatLink त्गाड़ https://doi.org/10.1787/888934079953

\section{Regulatory reforms can support further intangible investment}

New technologies often need to be accompanied by investments in knowledge-based capital. However, enterprises can be discouraged from making such investments due to their public good properties (Andrews and Criscuolo, 2013). That is, they are non-rival in their use and only partially excludable. As a result, greater intangible asset investment can be encouraged by the provision of appropriate protection for valuable information, knowledge and data not covered by patents or copyrights. In 2018, Ireland implemented the EU Directive 2016/943, which aims to standardise the national laws in EU countries against unlawful acquisition, disclosure and the use of trade secrets.

While this is a positive development, effective enforcement of the law would benefit from a reduction in legal service costs, which are particularly high in Ireland relative to other OECD countries (Figure 13). These can be particularly burdensome for small and medium enterprises that have tight operational cash flow (National Competitiveness Council, 2018). High costs partly reflect stringent regulations on legal services, as summarised by the OECD Product Market Regulation (PMR) indicators. In particular, restricting the form of legal business to sole proprietorships and prohibiting inter-professional co-operation unduly raises the cost of contract enforcement, notably in highly specialised and interdisciplinary areas such as intellectual property law. The Legal Services Regulations Act 2015 established the Legal Services Regulatory Authority as an independent watchdog for legal services. While it established new regulations to introduce legal partnerships and limited liability partnerships, no multi-disciplinary practices have yet been set up. To lower the very high costs of legal services, the Legal Services Regulatory Authority needs to be active in raising the transparency of legal costs and implementing regulatory reform that enhances competition in the sector. Allowing inter-professional cooperation in the provision of legal services will be a further step in this regard. 
Figure 13. Costs are high in the Irish legal services sector

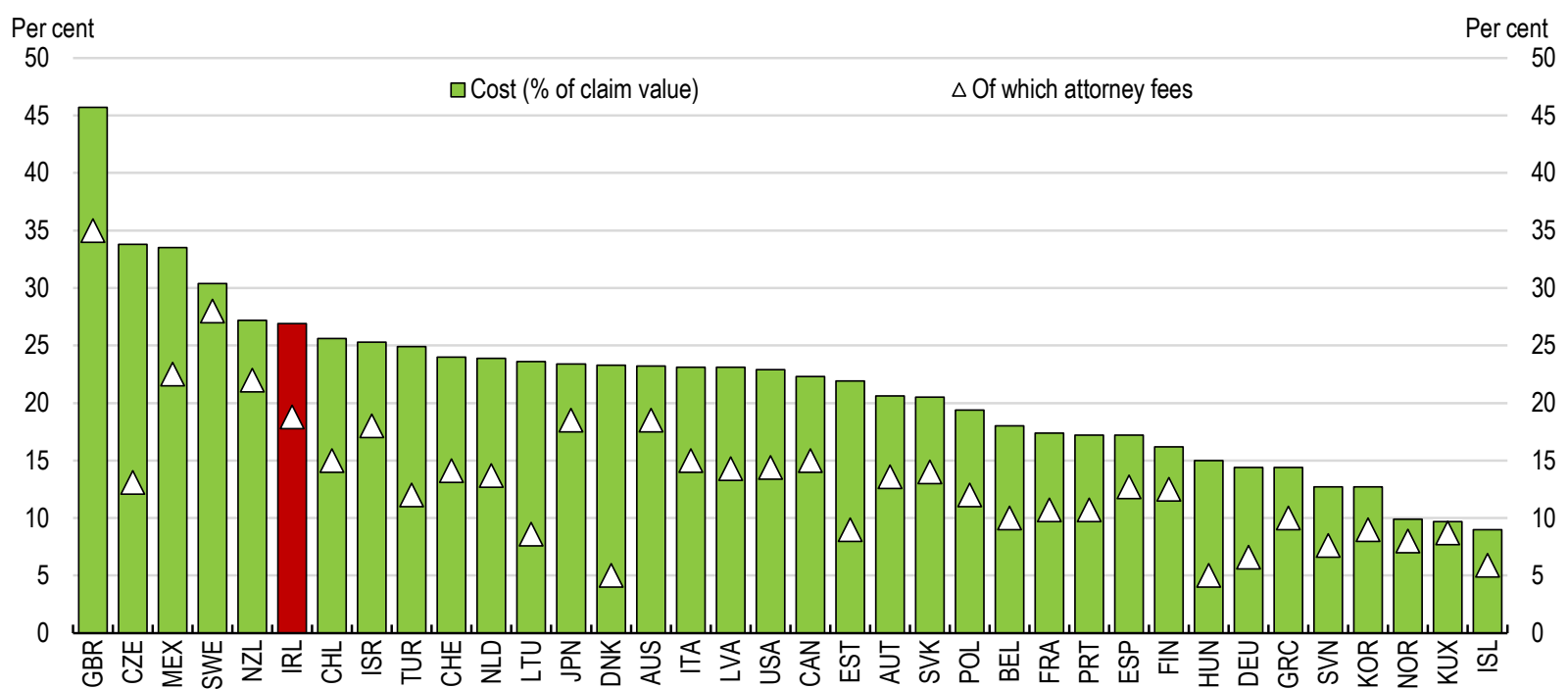

Note: Data relate to Mexico City for Mexico, Tokyo for Japan, and New York City for the United States, respectively.

Source: World Bank.

StatLink :

Promoting greater business dynamism is also key to encouraging the uptake of new technologies and thereby boosting productivity. Overall, the Irish sectors with lower productivity growth have tended to be characterised by low entry and exit rates (Figure 14). Business dynamism can be a source of competitive pressure that encourages improved resource allocation by firms. In striving to improve their performance, businesses look to integrate new technologies and use them in the most efficient way possible. In turn, economies that support efficient resource allocation can boost business dynamism through enabling high potential businesses to enter markets and grow unimpeded. Such an environment also promotes knowledge spillovers from frontier firms, which are especially important in the Irish context given the large productivity gap between foreign-owned and locally-owned firms.

In Ireland, business dynamism overall is relatively low (Figure 15, Panel A and Panel B). As discussed in the forthcoming OECD FDI Qualities and Impacts in Ireland, even foreign-owned firms are characterised by lower business dynamism compared to their peers in other countries (OECD, 2020a). Irish sectors with low business dynamism tend to be associated with lower labour productivity growth. This suggests that reforms that promote firm entry and exit can be important for reinvigorating Ireland's productivity performance. 
Figure 14. Labour productivity has been particularly weak in sectors with low firm entry and exit

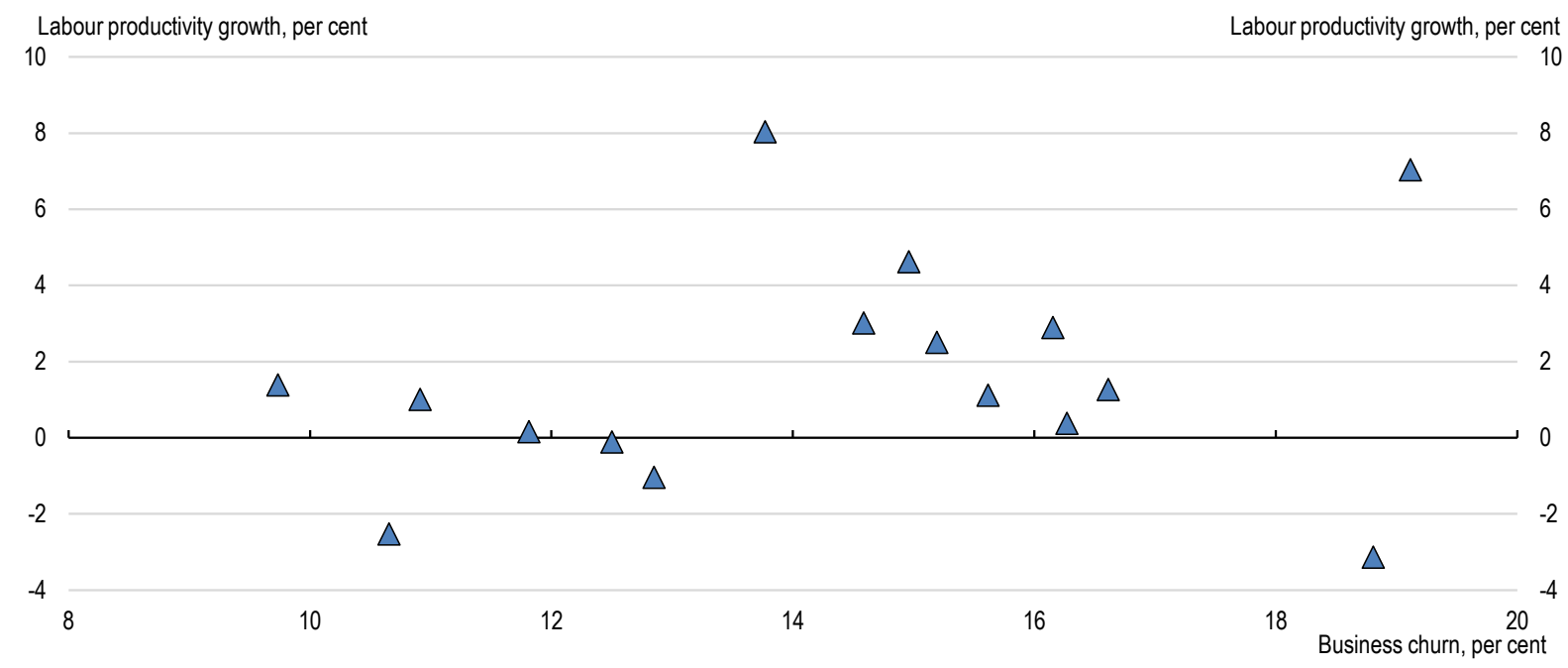

Note: The vertical axis refers to average annual labour productivity growth rates of 16 NACE Rev. 2 sectors over 2000-2017. The horizontal axis refers to business churn measured by the sum of firm births and firm deaths as a share of the total number of active firms in 2016. Firm deaths are measured by one year of inactivity.

Source: CSO.

StatLink 제 SR https://doi.org/10.1787/888934079991

Figure 15. Firm entry and exit rates are lower in Ireland than in many other countries

In 2017 or latest year available

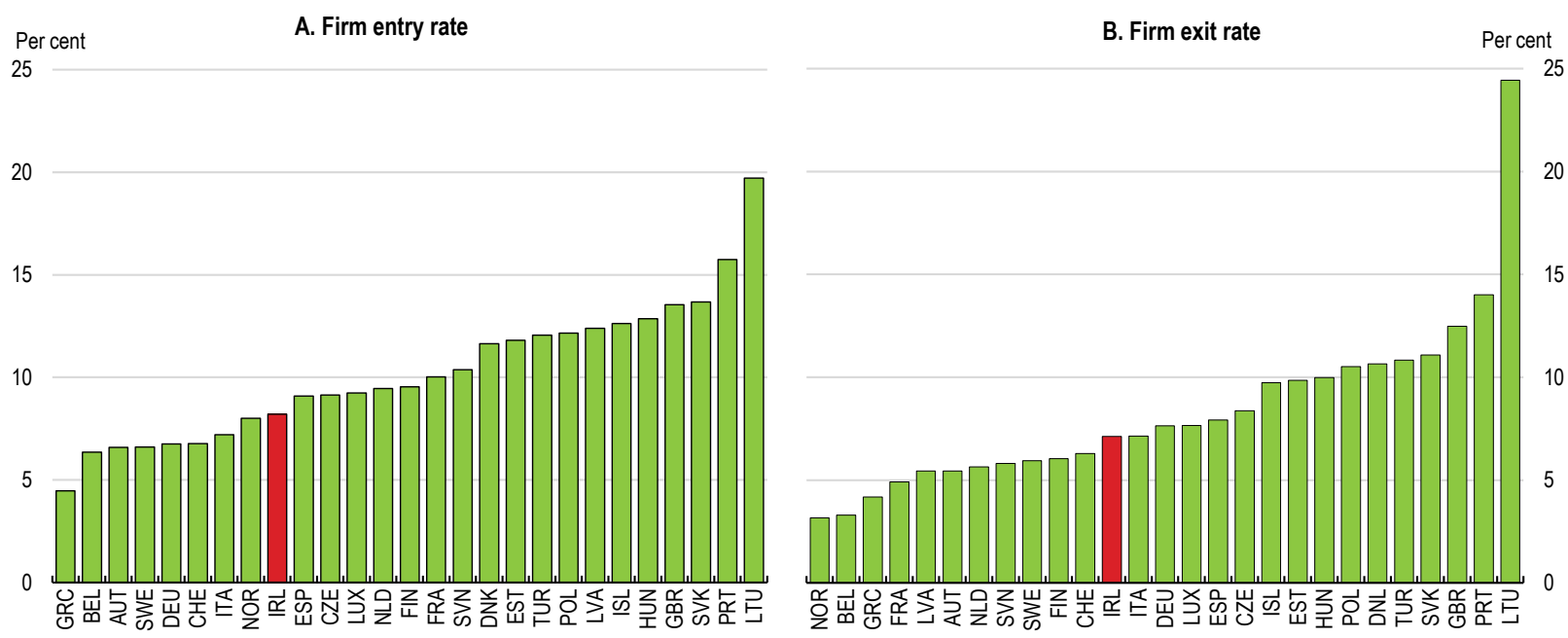

Note: The firm entry and exit rates are measured by firm births and deaths as a share of total number of active firms, respectively. The firm exit rate for Ireland is estimated as of 2016 based on one year of inactivity.

Source: Eurostat, CSO.

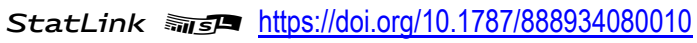

Some regulatory obstacles inhibit entrepreneurial activity and the growth of high-potential firms in Ireland. While the 2018 OECD PMR indicators show that the regulatory burden in Irish product markets is close to the OECD average, regulatory burdens on start-ups are relatively onerous (Figure 16, Panel A). More granular indicators show that the burden stems from complex regulatory procedures and the system for licences and permits (Figure 16, Panel B). The authorities have established an Integrated Licence 
Application Service, which allows businesses to renew and apply for licences online. Nevertheless, only a subset of the licenses necessary for businesses are available on the system, as participation by licensing authorities is not mandatory. The government should continue to monitor licensing requirements and the systems that facilitate them. Efforts should be made to link other existing licensing portals, such as that administered by the Revenue Commissioner, with the Integrated License Application Service. Furthermore, licensing authorities without online procedures should be required to participate, thereby establishing the service as a true one-stop shop for business licenses.

\section{Figure 16. Complex regulatory procedures and the licensing and permission process impede business activity}

\section{A. OECD PMR 2018 Indicators}

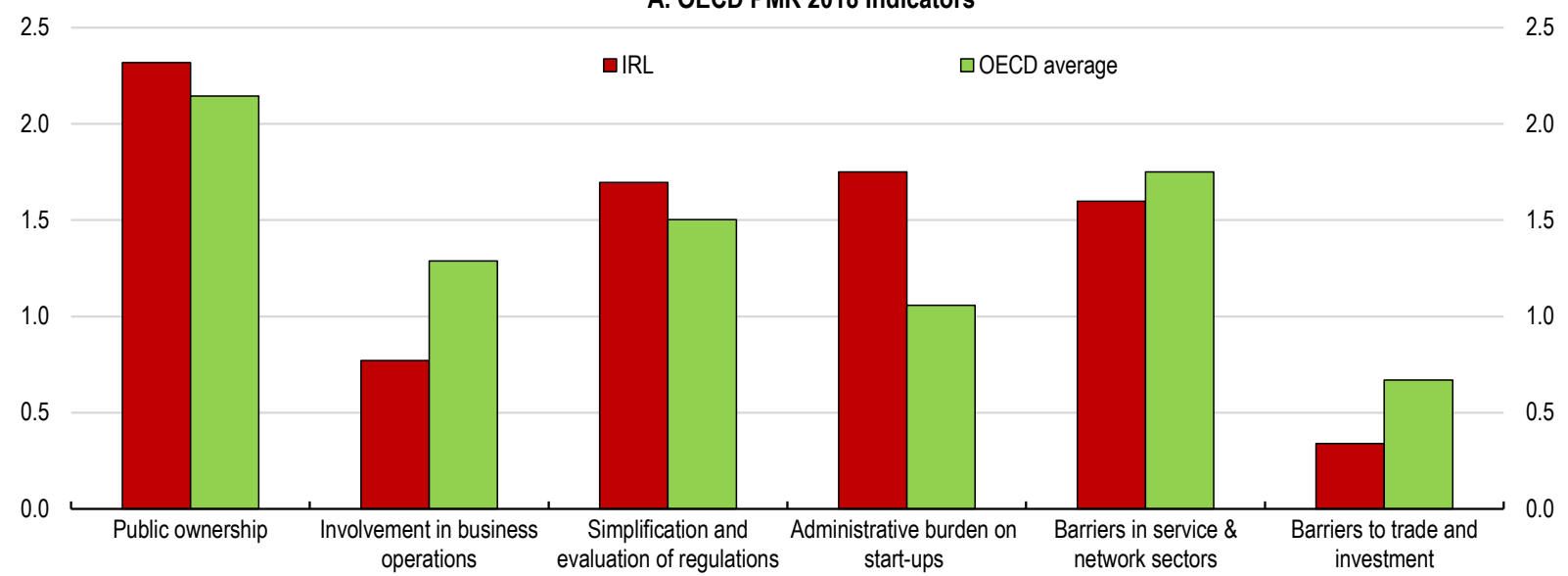

B. OECD PMR 2018 Indicators of simplification and evaluation of regulation and administrative burden on start-ups

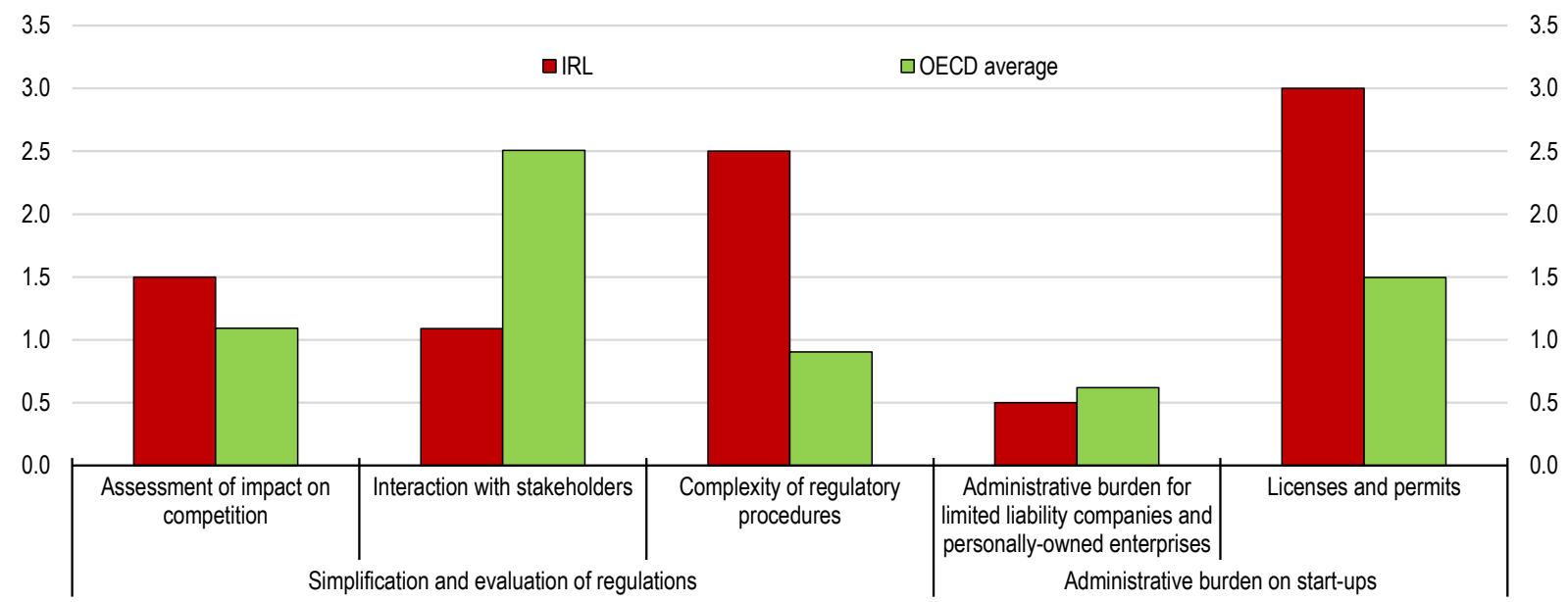

Note: The OECD Indicators of Product Market Regulation are a comprehensive and internationally-comparable set of indicators that measure the degree to which policies promote or inhibit competition. The indicator ranges from zero (least stringent) to six (most stringent). Source: OECD Product Market Regulations Statistics database.

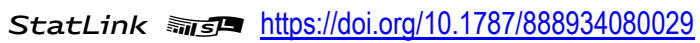

\section{Further easing financing constraints can also promote investment in technology by small young firms}

The ease of obtaining finance may also impact the adoption of new technologies and investment in complementary assets by firms (Andrews et al., 2018). In particular, there may be market failures in the 
provision of finance to small young firms that are seeking to invest. This is because such enterprises are more likely to lack credit history and collateral to secure a loan. The problem may be especially pronounced when such firms have a high share of intangible assets that are difficult to value, such as patents, or when they are involved in innovation processes that have uncertain outcomes. A recent report by the European Investment Bank found that Irish small and medium enterprises face barriers for accessing traditional bank finance for technological projects (European Investment Bank, 2019a).

In Ireland, borrowing conditions for small firms are tight. Data from the European Central Bank indicate that interest rates for Irish small and medium enterprises have been around 2 percentage points higher than in the average euro area country over the past few years. Furthermore, the spread between the interest rate charged to large firms and small and medium enterprises has been about 1 percentage point higher in Ireland than in the euro area. This partly reflects the relatively high default rates of small and medium Irish enterprise as well as limited competition between lenders. The banks in Ireland account for $90 \%$ of the market share of lending to small and medium enterprises (Central Bank of Ireland, 2019). As a consequence of high borrowing costs, borrowing by the sector has been weak.

Public institutions have introduced various measures to overcome the market failures associated with the financing of smaller and younger firms. Enterprise Ireland, a state agency focused on export-oriented businesses, manages various co-investment funds that match private funding with public support. Such an arrangement is beneficial in that it reduces the role of the public sector in "picking winners" but activities tend to be concentrated in those segments of the economy where such investors are already active.

The Strategic Banking Corporation of Ireland has also been established. This institution usually takes a wholesale lender approach whereby it provides funding to other financial institutions ("on-lenders") at attractive terms rather than directly lending to borrowers. The current set of on-lenders comprises three banks and four non-bank institutions, though there is scope to add more on-lenders as well as new products geared towards those firms facing the most severe financing constraints (National Competiveness Council, 2018). The Strategic Banking Corporation also manages the Credit Guarantee Scheme, which offers guarantees of up to $80 \%$ on SME loans, in return for a $2 \%$ annual premium to the insurer. In 2018, the scheme was revised to include new types of loans such as invoice discounting and factoring. Through Enterprise Ireland and the Local Enterprise Offices, authorities should continue to raise awareness of the existence of the scheme and these new features.

Efforts have also been made to promote equity financing as an option for small businesses. The Enterprise Security Market in the Irish Stock Exchange sets less strict listing and disclosure requirements for firms. However, the number of firms listed on the exchange remains limited. Ireland's Employment and Investment Incentive Scheme, a tax relief for investing in firms in early stages, is currently under review. In reforming the measure, the government should consider broadening its scope to cover those firms transitioning to public equity. Such a measure currently exists in the United Kingdom (the Employment and Investment Incentive Scheme). This would support equity financing of businesses listing on public exchanges.

Fintech has emerged as a new source of financing for young small firms that face financing constraints through the traditional banking system. Fintech includes lending-based crowdfunding and balance sheet lenders (leveraged non-bank institutions that transform risk and maturity). Online alternative financing is more common in Ireland than in most European countries. The Central Bank of Ireland has created an "Innovation Hub" to increase engagement between regulators and those fintech firms that do not have reporting requirements. While ensuring that the emergence of such firms does not contribute to the buildup of systemic financial risks, the authorities should encourage such new financing channels for the business sector, which can spur competition in the financial sector and bring down the price of borrowing for small and medium enterprises looking to invest in new technologies.

Some Big Tech companies with a large user base have also recently entered the EU payments market (e.g. Apple Pay, Google Pay and P2P payments and donations via Facebook Messenger). The growth of 
fintech firms may be constrained by the absence of an established customer base, limited access to soft information about potential customers, a lack of reputation and brand recognition and a higher cost of capital (Vives, 2019). However, most of these constraints do not apply to the Big Tech platforms, giving them substantial potential for disrupting financial markets. While this could put some competitive pressure on the banks, features of BigTech firms such as substantial network effects and the ability to restrict other companies from accessing their technological infrastructure could hamper competition (OECD, 2020b). The central bank and competition authorities should continue to closely monitor the level of market concentration in the non-bank financial sector.

\section{Skill needs are evolving as new technologies are embraced}

\section{Skill shortages are becoming more acute}

Worker skills play a crucial role in making the most of new technologies when they are incorporated into production processes. Complementary investments in organisational capital and skills have been identified as a key influence in the transmission of new technologies into productivity gains (Gal et. al. 2019). As outlined in Box 2, investment in economic competencies in Ireland has been relatively weak. Furthermore, despite high levels of formal educational qualifications and strong educational outcomes in schools (as measured by the Programme for International Student Assessment), the skills of Irish adults remain relatively low. The share of the population with university or equivalent level education is close to the OECD average for those between ages 55 and 64, and well above for those aged 25 to 34 (Figure 17, Panel A). Even so, their literacy skills remain close to the OECD average, and numeracy and problem solving skills are significantly lower for all age cohorts (Figure 17, Panel B, C and D).

The comparatively modest skill level of the Irish population may be a factor in explaining significant skill shortages, relative to other countries, in the context of rapid technological adoption. In 2015, skill shortages reported by Irish employers were more severe than in other OECD countries. Greater skill needs were reported in all categories ranging from basic content and process skills such as reading and writing, mathematics and critical thinking, to systems skills such as decision-making and resource management skills (Figure 18). The period since then has seen a further rise in shortages of labour, with a steady increase in the ratio of new job vacancies to unemployed (Figure 19). 
Figure 17. Skills of Irish adults are lower than indicated by formal qualifications

By age cohort
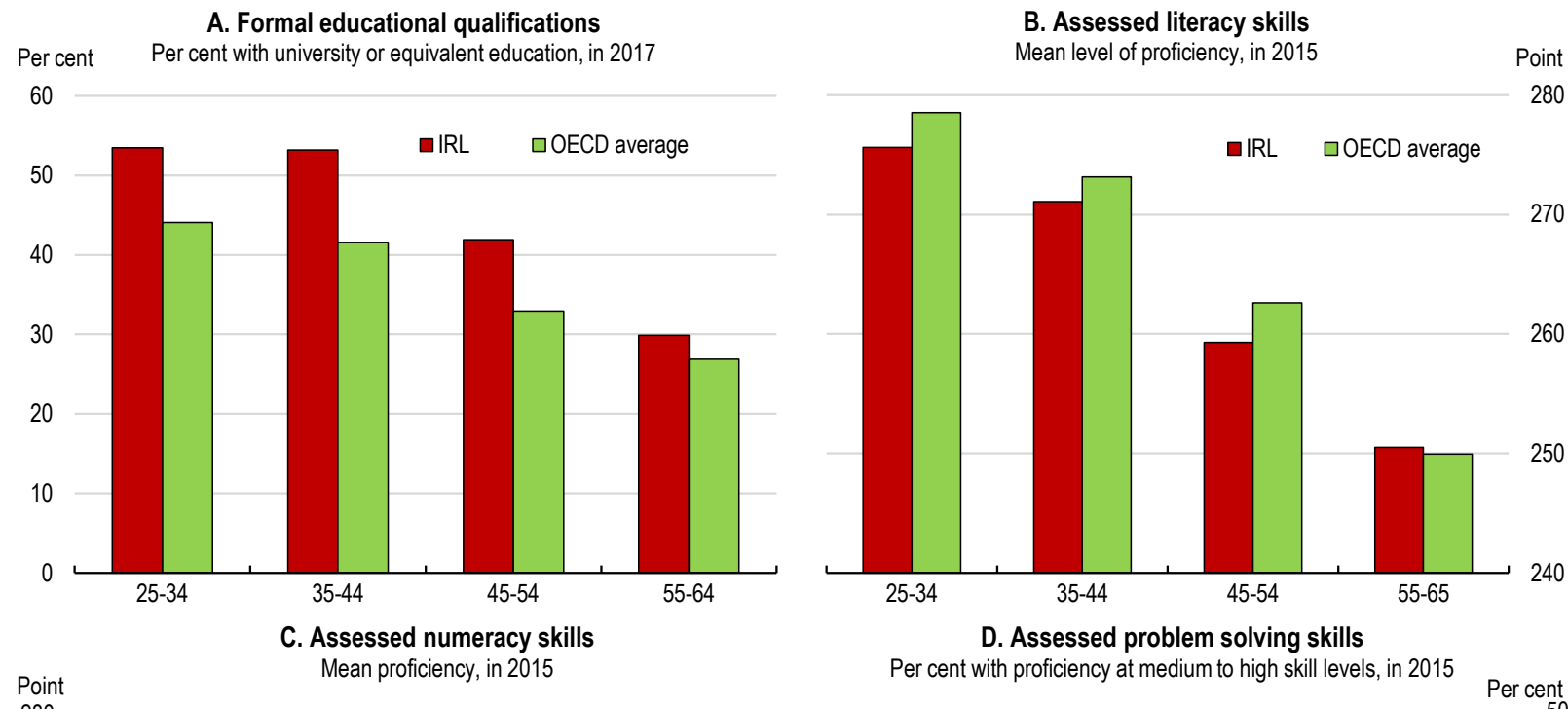

$280 \square$ aRL $\square$ OECD average

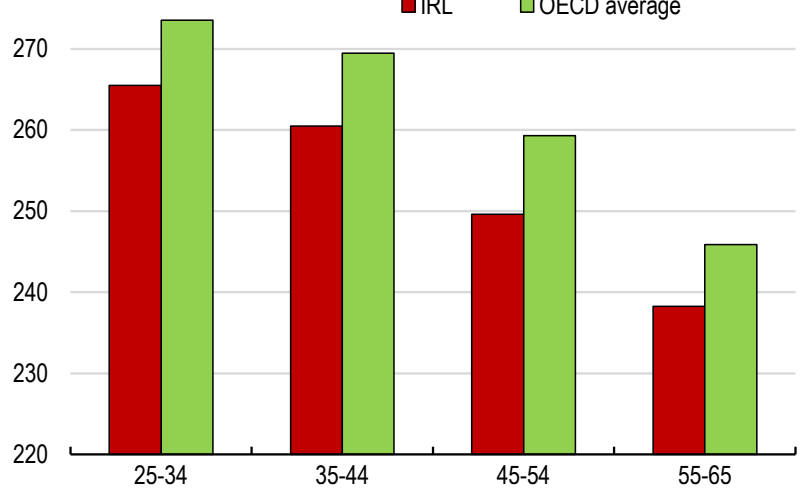

D. Assessed problem solving skills

Per cent with proficiency at medium to high skill levels, in 2015

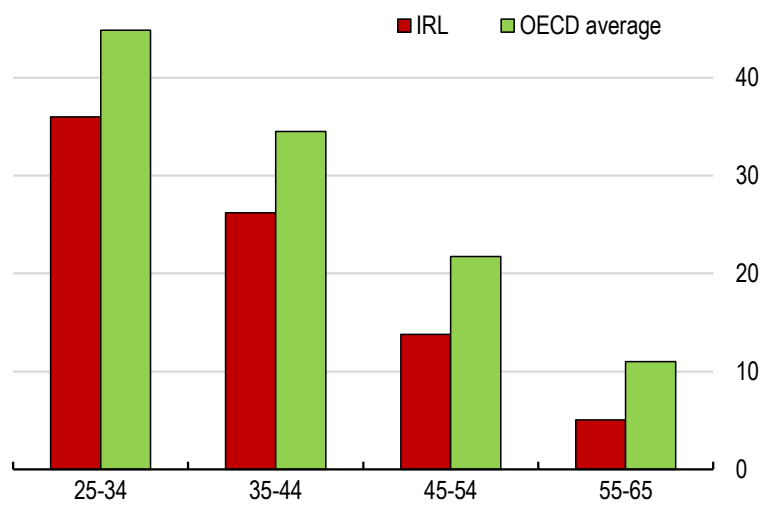

Note: Panel A shows the share in the population. Panel B, C, and D shows the mean scores of and the share in the respondents of the OECD Survey of Adult Skills.

Source: OECD Educational Attainment dataset, OECD Survey of Adult Skills (PIAAC).

StatLink : 
Figure 18. Skill shortages in Ireland stand out

Index normalised between -1 and 1, 2015

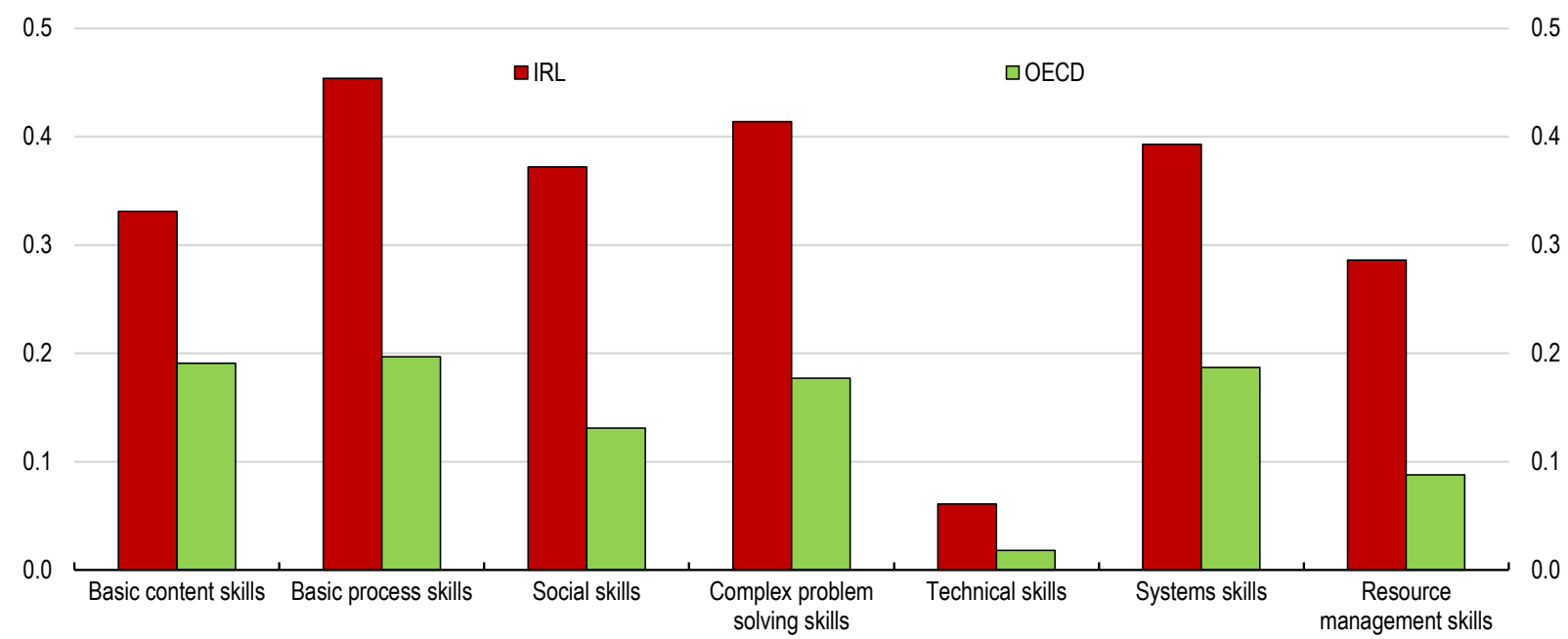

Note: Positive values represent shortages, while negative values correspond to surpluses, on a scale that ranges between 1 and -1 .

Source: OECD Skills for Jobs database.

StatLink 제는 https://doi.org/10.1787/888934080067

\section{Figure 19. The labour market has been tightening}

Number of new vacancies per unemployed worker

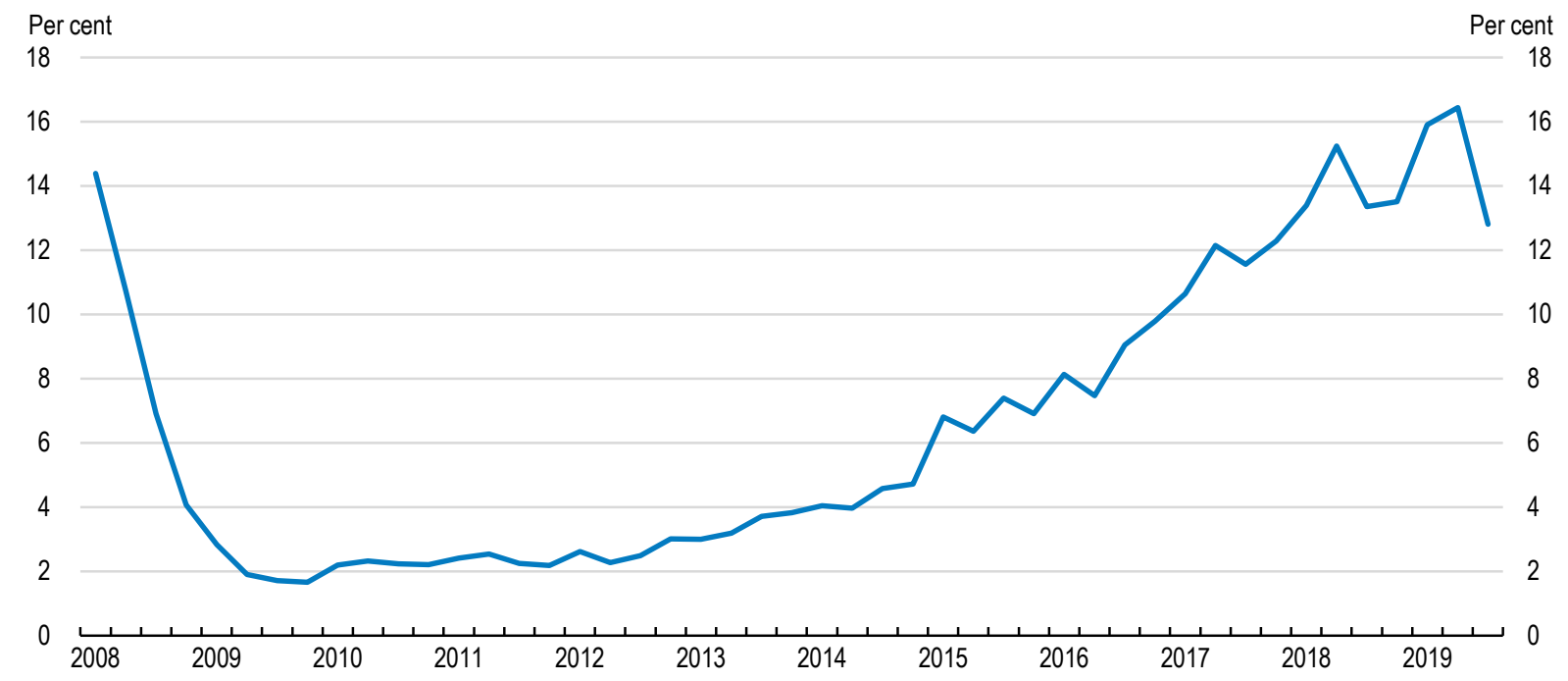

Source: CSO.

StatLink त्ता Th https://doi.org/10.1787/888934080086

\section{Technological progress requires active lifelong learning}

Severe skill shortages may become a serious impediment to the further uptake of new technologies and productivity growth. Recent empirical studies by the OECD show that, in addition to low managerial quality, lack of ICT skills and mismatches of workers to jobs curb digital technology adoption and diffusion (Andrews et al., 2018; Gal et al., 2019). Indeed, 76\% of Irish firms reported unavailability of staff with the right skills as one of the major obstacles to investment (European Investment Bank, 2019b). Given that 


\section{6}

ECO/WKP(2020)18

multinational firms can more easily attract workers as they pay higher wages (OECD, 2018a), this problem can be particularly pronounced for smaller locally-owned Irish firms.

In turn, technological adoption can exacerbate skills shortages by making the skills obtained through formal education obsolete. In $2016,29.5 \%$ of jobs in Ireland were performed by underqualified workers, the highest in the OECD (Figure 20, Panel A). A cross-country comparison highlights a positive relationship between intensity of intangible investment and underqualification of jobs (Figure 20, Panel B). This suggests that investments in innovative properties and software lead to a greater need for re-skilling workers. Over the past decade, Irish sectors with higher intangible investment rates tended to experience a significant rise in job vacancy rates (Figure 21). The Further Education and Training Authority of Ireland (SOLAS) has found that the difficulty of filling vacancies by occupation has recently increased (McNaboe et al. 2018). In particular, more than half of recruitment agencies surveyed in April 2019 reported skills as a barrier to filling vacancies for ICT professionals and production and process engineers.

\section{Figure 20. Greater intangible capital investment necessitates re-skilling}
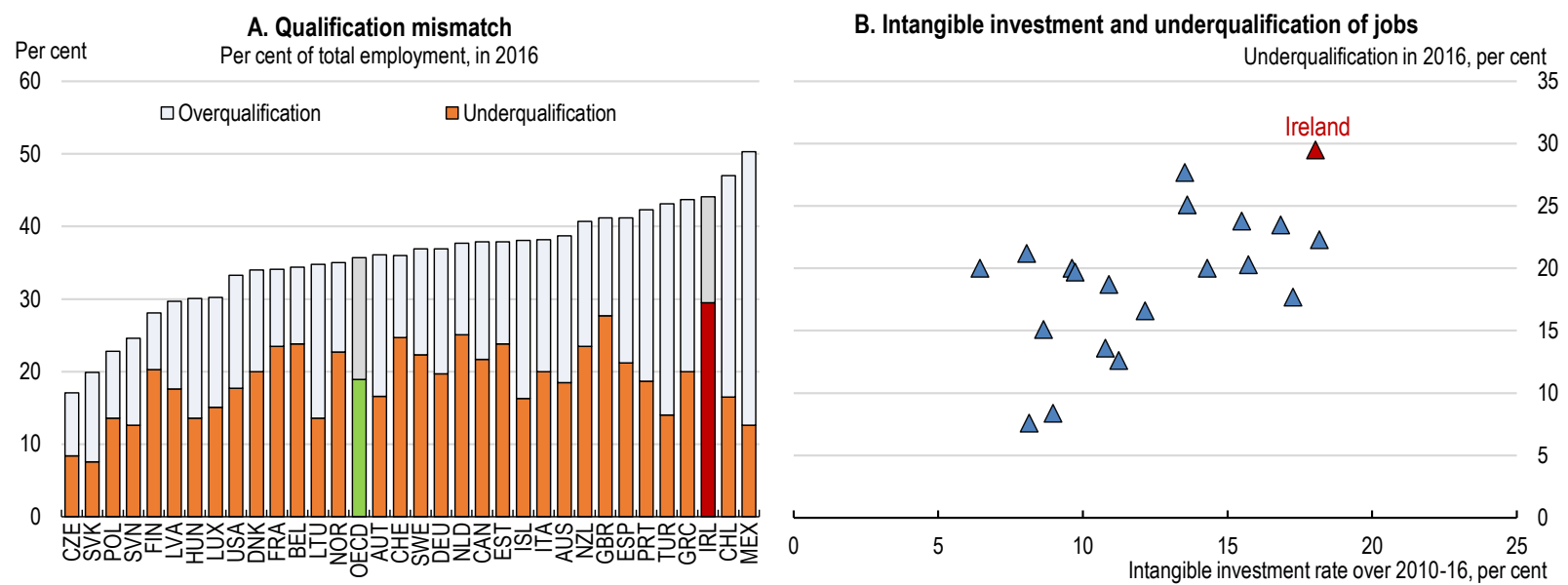

Note: In Panel A, jobs are classified as overqualified when workers have an educational attainment that is higher than that required by them, while classified as underqualified if the opposite is true. In Panel B, data cover 19 European countries and the United States. Intangible investment rate is average investment in innovative properties, software, and economic competencies as a share of value-added over the period. Source: OECD, INTAN-INVEST database.

StatLink ज्ञाज https://doi.org/10.1787/888934080105

These developments suggest that further technological diffusion in the Irish economy will increasingly need workers to obtain new skills. This requires an effective adult learning system that provides continuous opportunities to develop, maintain and upgrade skills through learning and training at all ages (OECD, 2019a). While the formal education system must equip graduates with the new skills needed, comparatively low participation in other lifelong learning opportunities suggests that these should be a particular focus for policymakers. Past work has highlighted an array of skill areas that may need honing to succeed in technology-rich work environments. These include complex problem solving and general cognitive skills, notably literacy, numeracy and ICT skills (OECD, 2019a). The latter will also be important for encouraging Irish citizens' use of digital government services (Figure 7 further above). The recent OECD review of SME and Entrepreneurship Policy in Ireland underscores the need to better encourage the accumulation of digital skills in small and medium enterprises (OECD, 2019b). 
Figure 21. Sectors with high intangible investment face difficulties in filling job vacancies

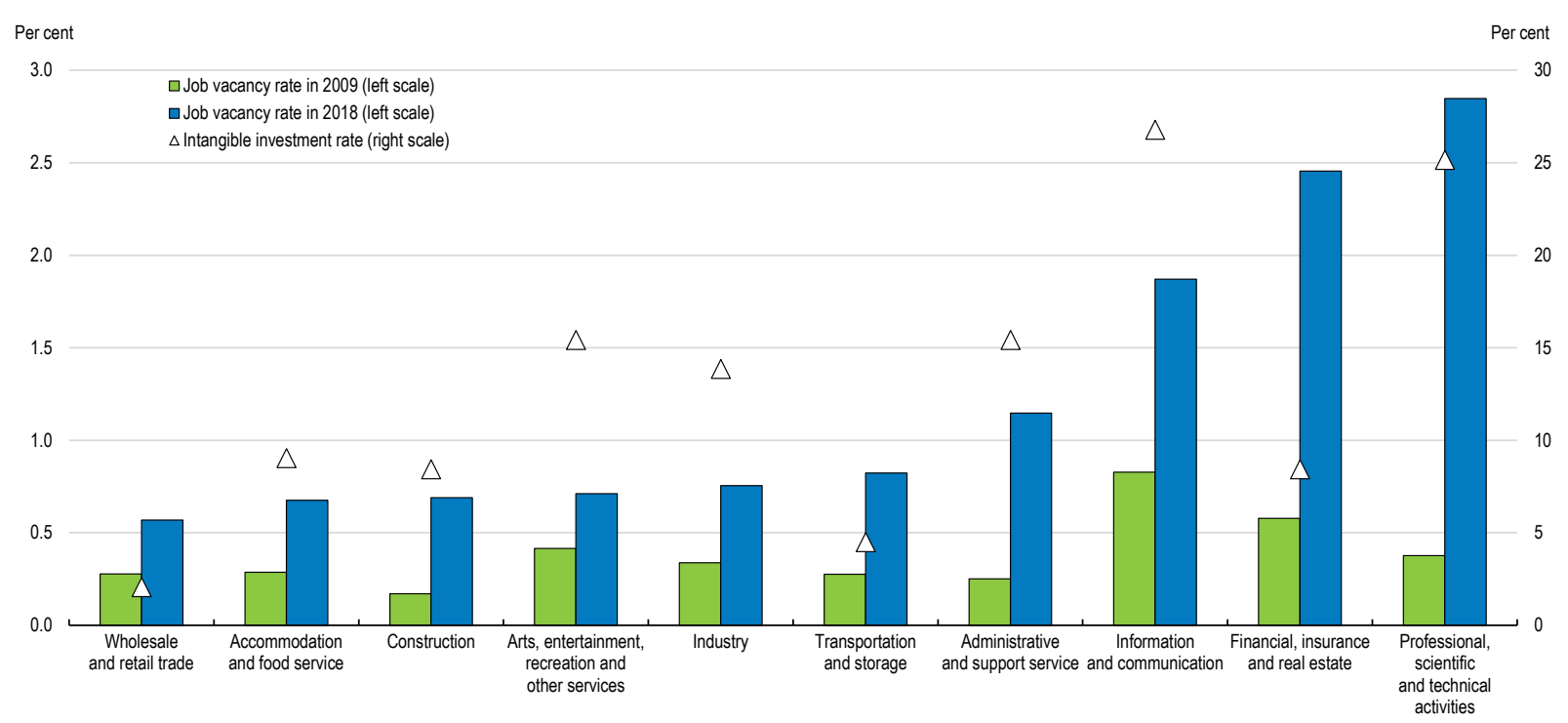

Note: Intangible investment rate is average investment in innovative properties, software and economic competencies as a share of value added over 2009-2015.

Source: CSO, INTAN-Invest database.

StatLink 젶ㄴ https://doi.org/10.1787/888934080124

\section{There is scope for improving the adult learning system in Ireland}

The Irish adult learning system has performed better than the OECD average in aligning learning provision to the needs of the labour market and in providing impactful programmes in terms of wage returns and perceived usefulness (Figure 22, Panel A). A survey by the Higher Education Authority reported that the vast majority of employers were satisfied with recent higher education and further education and training graduates across a range of personal and workplace attributes, including technical literacy and communication and numeracy skills (Higher Education Authority, 2019).

Nevertheless, increasing trade openness and rapid changes in industrial structures are calling for updating the Irish adult learning system with greater urgency. In addition, the adult learning system performs worse than the OECD average in terms of its flexibility and guidance of individuals and financial arrangements. While recent decades have seen an increase in the participation rate in lifelong learning activities in Ireland (European Commission, 2019), it was still only around the median of European countries at $12.5 \%$ in 2018 (Figure 23, Panel A). Participation is particularly low relative to other countries for young Irish workers with lower-secondary and tertiary education (Figure 23, Panel B). As in other European countries, older workers participate less in adult education than younger workers. 


\section{Figure 22. Performance indicators for the adult learning system are mixed}

Indicators normalised to $0-1,1=$ top OECD country and $0=$ bottom OECD country
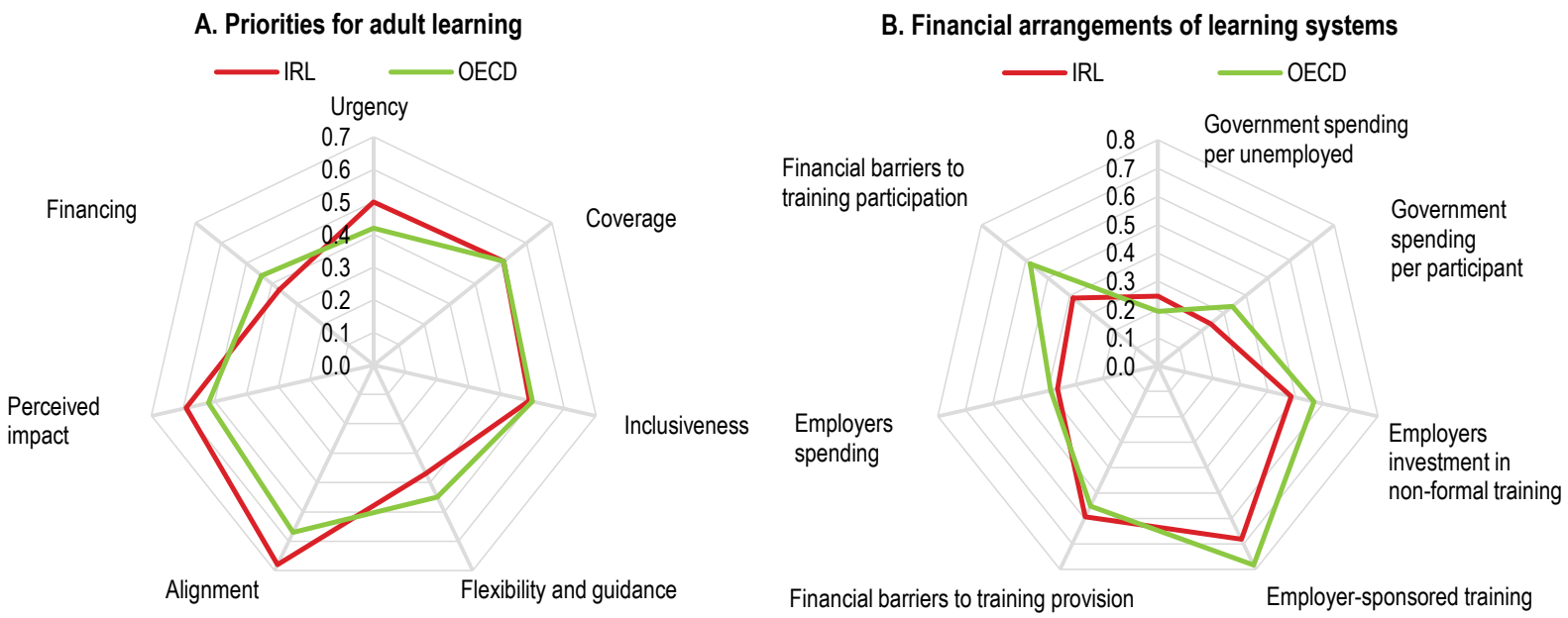

Note: In Panel B, the indicators for financial barriers to training participation and financial barriers to training provision take a higher value for a lower barrier, and vice versa.

Source: OECD Priorities for Adult Learning Dashboard; OECD calculations.

StatLink 제대 https://doi.org/10.1787/888934080143

According to a survey by the European Commission, a lack of perceived need for training is the primary reason for individuals not participating in programmes across all age groups (Table 2). It also shows that around $20 \%$ of the adult population searched for information on training and education, below the average of OECD members at $26 \%$. This highlights the need for better promoting the benefits of education to workers and orienting them towards relevant courses. In addition, some age groups face distinct barriers to training participation. For example, the cost of training is cited as an obstacle by $26.8 \%$ of those aged between 25 and 34, higher than in some other countries with higher participation such as Denmark, Finland and Sweden. While training cost becomes less important for older age groups, family responsibilities become more of a constraint. Almost one in five workers aged between 55 and 64 see health or age as an obstacle to participation in education programmes.

Financial arrangements for training programmes are a particularly important issue for adult learning in Ireland. The OECD Survey of Adult Skills (PIAAC) reported that $20.7 \%$ of those who wanted to participate in training chose not to do so because they found it unaffordable. Public financial support for lifelong learning should be designed taking into account that cost is a particularly strong impediment to training participation at early stages of work life. In Ireland, per participant public spending on training, firms' investment in non-formal training as a share of gross value added and provision of employer-sponsored training are lower than the OECD average (Figure 22, Panel B). Since 2000, firm funding of structured training as a share of payroll costs has steadily fallen for both locally-owned and multinational enterprises. 
Figure 23. Young and older workers must be better encouraged to participate in training

\section{A. Participation rate in adult learning}

Per cent

Per cent

35

30

25

20

15

10

5

0 SVK GRC POL HUN TUR LTU LVA ITA DEU BEL CZE PRT ESP SVN IRL GBR AUT LUX FRA NLD EST NOR ISL DNK FIN SWE CHE

Per cent

B. Participation rate in adult learning by age and educational attainment

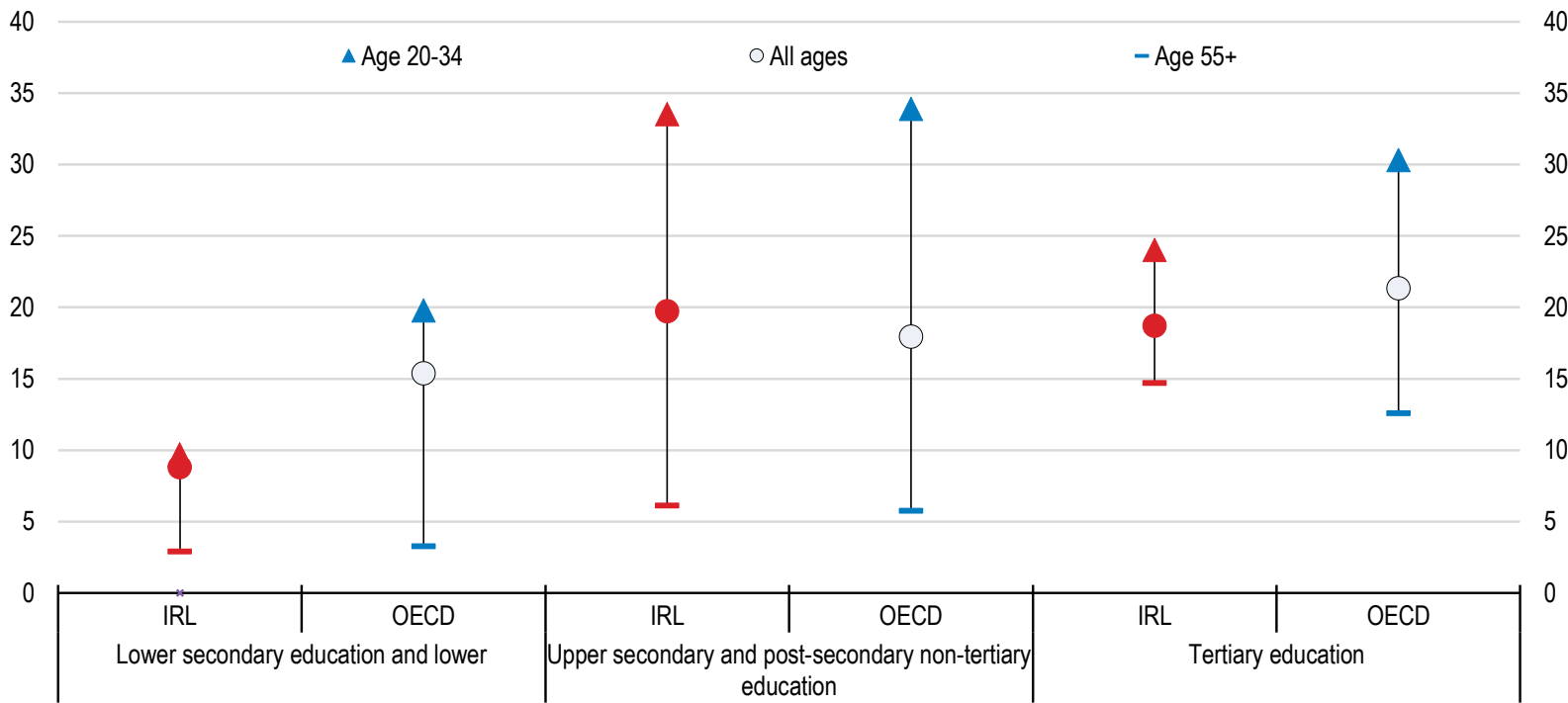

Note: All data are for 2018. Panel A shows the share of adults aged 25-64 who participated in formal and non-formal education and training during the four weeks preceding the survey. Panel B shows the share of adults aged 18-74 who participated in formal and non-formal education and training during the four weeks preceding the survey. In Panel B, OECD refers to the non-weighted average of 27 European members of the OECD except for the group for age 55 and more with lower secondary and lower education levels, where the average of 21 European countries is shown due to availability of data.

Source: Eurostat, Adult Education Survey.

StatLink 젠 https://doi.org/10.1787/888934080162 


\section{Table 2. Obstacles to participation in education and training}

In 2016, per cent

\begin{tabular}{rccccccccrrr}
\hline Age & $\begin{array}{c}\text { No } \\
\text { perceived } \\
\text { need }\end{array}$ & $\begin{array}{c}\text { Family } \\
\text { responsi- } \\
\text { bilities }\end{array}$ & Schedule & Cost & $\begin{array}{c}\text { Health } \\
\text { or age }\end{array}$ & Distance & $\begin{array}{c}\text { No suitable } \\
\text { education } \\
\text { or training } \\
\text { activity }\end{array}$ & $\begin{array}{c}\text { Lack of } \\
\text { employer or } \\
\text { public } \\
\text { services } \\
\text { support }\end{array}$ & $\begin{array}{c}\text { Other } \\
\text { Pre- } \\
\text { requisites }\end{array}$ & $\begin{array}{c}\text { personal } \\
\text { reasons }\end{array}$ \\
\hline $25-34$ & 51.3 & 30.2 & 25.7 & 26.8 & - & 5.6 & 5.5 & 5.0 & - & 9.3 \\
\hline $35-44$ & 47.7 & 44.5 & 23.9 & 19.5 & 5.4 & 5.8 & 3.5 & 4.5 & 3.5 & 11.0 \\
\hline $45-54$ & 57.0 & 39.6 & 21.1 & 16.3 & 8.1 & 7.3 & 4.8 & 4.8 & 3.2 & 7.9 \\
\hline $55-64$ & 57.0 & 24.9 & 16.5 & 10.4 & 17.0 & 4.3 & 4.9 & - & 3.1 & 10.8 \\
\hline
\end{tabular}

Source: Eurostat, Adult Education Survey.

Ireland is raising the National Training Fund (NTF) levy, which finances programmes for those seeking employment as well as in-employment training, from $0.7 \%$ to $1.0 \%$ of payroll over $2017-2020$. While this is increasing available resources, the training fund can improve the incentives for employers to invest in training by moving towards a more demand-driven scheme. Conversion of the revenue-generating scheme to a cost-reimbursement scheme, in which firms pay a levy but can claim expenses back for training costs they incur, would enhance incentives for training provision (IBEC, 2017). This should increase the number of training opportunities provided by small firms. While $94.9 \%$ of large firms in Ireland provided continuing vocational training in 2015 , only $74.8 \%$ of small firms with employees between 10 and 49 did so (Figure 24). To avoid a fragmentation of the fund and ensure training is aligned with overall skill priorities, such an arrangement should be based on consultations with employers through the NTF Advisory Group.

\section{Figure 24. Smaller firms tend to train less than larger firms}

Percentage of firms providing continuing vocational training, in 2015

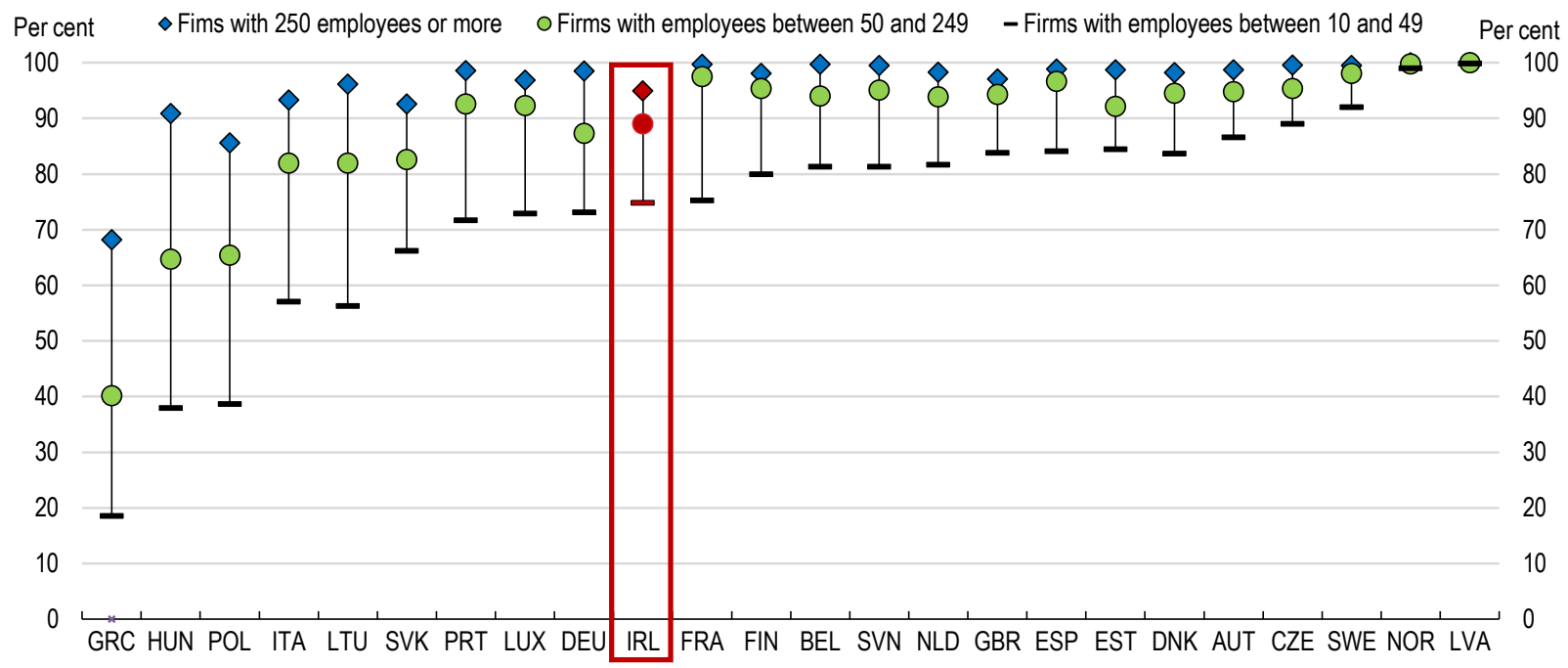

Source: Eurostat.

StatLink ज्ञाज्य https://doi.org/10.1787/888934080181

In addition, a better mix of financial incentives should be achieved by considering various measures including: i) a further shift of active labour market policies toward training (discussed further below); ii) the introduction of paid training leave; and iii) the provision of preferential loans to cover training costs to 
individuals. Ireland provides no statutory entitlement to training leave, which is common in the majority of European countries that have comparatively high training participation. Provision of paid training leave and preferential loans alongside statutory leave would encourage training uptake by both older and younger workers, who tend to face higher opportunity costs and liquidity constraints on learning, respectively. For example, France compensates workers undertaking training leave for between 80 and $100 \%$ of their wage, while Austria provides an allowance equivalent to the unemployment benefit. Advanced Learner Loans in England and Lifelong Learning Loans (Levenslanglerenkrediet) in the Netherlands provide loans for upskilling and reskilling. Such programmes usually have repayment due at the end of the course and may alter the amount due depending on post-training earnings. Furthermore, as in some European countries, establishing payback clauses in labour contracts can be an option to prevent disputes between employers and employees over training costs in the context of increasing worker mobility (European Centre for the Development of Vocational Training, 2012).

Policies that support childcare assistance may help reduce the burden from family responsibilities for middle-age groups. In this regard, the full introduction of income-related subsidies for childcare under the National Childcare Scheme will be important. However, the increase of childcare benefits should be accompanied by measures to curb mounting childcare fees, including expansion of childcare capacity (OECD, 2020b). Given that shortage of time is a major obstacle across all age groups, the Irish adult learning system should enhance its flexibility through greater use of distance learning. In 2015 , only $10 \%$ of trainees participated in a distance learning programme, a low share compared with other OECD countries. As part of the government's "Human Capital Initiative", some funding has been provided to higher education institutions to develop online learning courses. In addition, facilitating flexible arrangement of working hours would also help, including through statutory entitlement to reduced work hours for training reasons.

\section{The nature of some jobs will change with greater technological diffusion}

As discussed, new technologies will be the basis for the creation of new products and services and open up the markets for new types of equipment and skills. Through raising productivity, technological advances can reduce prices and improve quality, boosting aggregate demand and benefitting consumers. These processes will create new jobs. Indeed, recent OECD empirical work has highlighted that investments in information and technology in Ireland have delivered significant job creation (OECD, 2020a). However, technological transformation leads to creative destruction. While many jobs are created, some will change and others will be lost (Frey and Osborne, 2013; Nedelkoska and Quintini, 2018). Focusing on Ireland, estimates suggest that around $16 \%$ of jobs are at high risk of automation, slightly above the OECD average. A further $27 \%$ of jobs will likely face significant change in how they are performed (OECD, 2019c).

New empirical research undertaken for this Economic Survey suggests that while technological change has not impacted job loss rates in Ireland overall, it may have been associated with displacement in some sectors that have been identified as having high automation risk (Box 3). Such sectors tend to be located in regions of Ireland that have relatively low incomes and were hardest hit through the crisis (Doyle and Jacobs, 2018). Furthermore, they have workers with lower education levels (Doyle and Jacobs, 2018). This comes on the back of already rising levels of job polarisation, with the share of high-skilled jobs having increased at the expense of middle-skilled jobs (Figure 25). 


\section{Figure 25. Jobs growth has been particularly strong for those with high skill levels}

Percentage point change in share of total employment, by skill level, 1995 to 2015

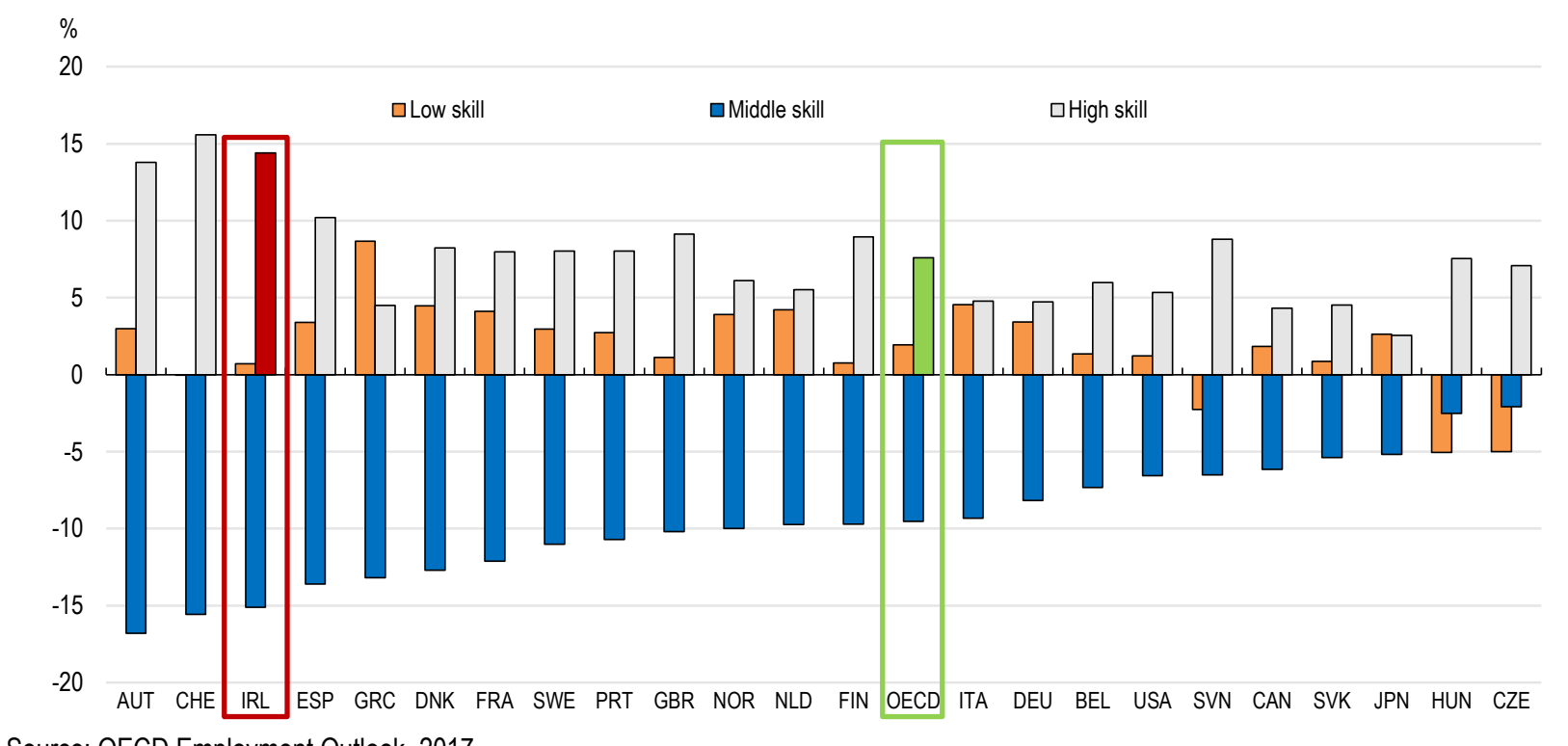

Source: OECD Employment Outlook, 2017.

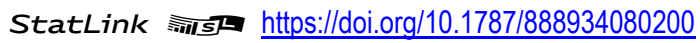

In this context, providing people with the right skills to succeed in a technologically rich world is important. As already discussed, improving education and training systems, especially for adults, will be key. The reallocation of workers across industries will also need to be facilitated, including by helping them transition to new geographic areas of work that are thriving (discussed further below). This transition must be accompanied by social protection systems that support displaced workers and effectively reorient them towards new higher productivity jobs.

\section{Box 3. Has technological adoption in Ireland been associated with job losses?}

Limited empirical work has been done focusing on the extent to which technological adoption has already been associated with any job displacement in Ireland. To shed some light in this area, this analysis explores whether job loss rates have been associated with intangible capital investment at the industry level. The indicator of job loss is aggregated up from the firm level, whereby a decline in the number of paid employees in a given year is recorded as job loss. An increase in the number of paid employees at a firm in a year is recorded as no job loss, meaning the indicator is truncated at zero.

The empirical approach uses the following regression equation:

$$
\Delta J L_{i, t}=\alpha_{1} \Delta \text { Intangibles }_{i, t}+\alpha_{2} \Delta G V A_{i, t}+\delta_{i}+\gamma_{t}(1)
$$

Where $\Delta$ denotes the log difference, $J L$ is the job loss rate at the industry level (i) in a given year ( $t$ ). Consistent with past studies (e.g. Bassanini and Scarpetta, 2002), intangible assets are used as a proxy for embodied technological change. Intangibles is a vector of variables that relate to the intangible capital stock (and these are measured as a ratio to the total stock of all fixed assets). Specifically, the data decompose the total real intangible capital stock into that component related to computer software and that related to business R\&D. GVA is a measure of real value added by industry. This is included to control for the impact of cyclical conditions on changes in job loss. 
As mentioned, the existing literature underscores that while intangible capital accumulation may substitute for labour in some sectors it may complement it in others. This is problematic for the estimation of the $\alpha_{1}$ coefficients in the above equation. As a result, past work by Doyle and Jacobs (2018) is used to identify the sectors in Ireland that are at high risk of job automation. This is combined with the information in Table 1 (further above) to create a dummy variable representing sectors with relatively high automation risk that have seen strong ICT investment relative to other comparable countries in the recent period. This dummy is then used to create an interaction term that is added to the estimation equation:

$$
\Delta J D_{i, t}=\boldsymbol{\alpha}_{\mathbf{1}} \Delta \text { Intangibles }_{i, t}+\alpha_{2} \Delta G V A_{i, t}+\alpha_{3} \text { Intangibles }_{i, t} * \text { High Autom. Risk } \text { Ant }_{i}+\delta_{i}+\gamma_{t}
$$

The $\alpha_{1}$ coefficients in equation (2) is the estimated effect of growth in the given measure of the intangible capital stock on the growth of job loss rates at the sample mean. The $\alpha_{3}$ coefficient captures any additional estimated effect for those industries with high automation risk. A positive coefficient on the interaction term (i.e. $\alpha_{3}$ ) suggests that high automation risk industries have been associated with greater job loss as a result of intangible capital accumulation than the average Irish industry over the time horizon.

The results of the regression analysis are presented in Table 3. As expected, the negative estimated coefficient on the GVA term highlights that improvements in gross value added in an industry are associated with a lower job loss rate. Column 1 highlights that increases in the growth rate of the measure of computer software intensity have not been associated with greater job loss rates in the average industry. However, there has been a positive relationship between the job loss rate and computer software intensity in those industries deemed to have high automation risk and recently strong intangible relative to tangible capital accumulation. Similarly, the results in Column 2 suggest that growth in business R\&D has been associated with job loss in high automation risk industries, though the effect is not as large or statistically significant as that for computer software.

\section{Table 3. Estimation results}

Dependent variable $=\Delta J L_{i, t}, 2006-15$

\begin{tabular}{|c|c|c|}
\hline & (1) & (2) \\
\hline$\Delta$ Comp. Software $_{i, t}$ & $\begin{array}{l}-0.04 \\
(0.8)\end{array}$ & \\
\hline$\Delta$ Comp.Software $_{i, t} *$ High Autom. Risk ${ }_{i}$ & $\begin{array}{l}1.23^{\star \star \star} \\
(2.82)\end{array}$ & \\
\hline$\Delta R \& D_{i, t}$ & & $\begin{array}{c}0.07 \\
(1.33)\end{array}$ \\
\hline$\Delta R \& D_{i, t} *$ High Autom. Risk ${ }_{i}$ & & $\begin{array}{c}0.69^{*} \\
(1.89)\end{array}$ \\
\hline$\Delta G V A_{i, t}$ & $\begin{array}{l}-0.53^{*} \\
(1.78)\end{array}$ & $\begin{array}{c}-0.81^{*} \\
(1.83)\end{array}$ \\
\hline Observations & 90 & 89 \\
\hline $\mathrm{R}^{\wedge} 2$ & 0.46 & 0.58 \\
\hline
\end{tabular}

Note: ${ }^{*},{ }^{* *},{ }^{* * *}$ denotes statistical significance at the $10 \%, 5 \%$ and $1 \%$ level respectively. T-statistics are presented in parentheses. All regressions include time and industry fixed effects, robust standard errors and are estimated with a lagged dependent variable. The regressions are estimated across 12 industries during the years for which the CSO publishes job churn statistics and for which other indicators are available. The results are robust to the exclusion of the GVA term from the regressions. 
Taken together, these results suggest that the impact of intangible capital on the labour market cannot be generalised. In some industries, growth in intangibles may even be associated with lower job loss. Nevertheless, it does appear that increased growth in the stock of computer software has been associated with job displacement in some Irish industries identified as having high automation risk. As detailed by Doyle and Jacobs (2018), some high automation risk industries such as wholesale and retail trade have shed workers over the past decade.

The analysis presented here does come with several caveats and opens up areas for further work. The dependent variable is an imperfect measure of job displacement, as it could miss significant disruption in jobs if the number of paid employees is little changed between years. Better information with regard to gross job flows (as opposed to a net measure) and the reasons for job separations could provide important insights. Furthermore, further work assessing the parts of the Irish economy that have experienced the most rapid job creation from technological progress could provide a better understanding of the sources of Irish economic growth.

Critical to raising re-employment prospects for displaced workers is a system of well-designed and adequately resourced active labour market programmes. These should provide displaced workers with timely access to basic job search services and target the workers that require more intensive reemployment services or retraining.

Total spending on active labour market programmes per unemployed worker in Ireland is around the OECD average, but a relatively high share of spending is for direct job creation. The effect of such measures is immediate, but the programmes are usually time limited and subsequent employment prospects can be modest (Card et al., 2015). While some spending is focused on social inclusion objectives, consideration should be given to reorienting active labour market policies further towards training programmes. Such spending is likely to have a longer-lasting positive employment effect, provided that the programmes are well-designed. In particular, training programmes should be further developed that specifically target those transitioning to new jobs as a result of technological advances.

To the extent possible, training should be targeted at workers before they lose their job. In Luxembourg, a pilot programme called "Digital Skills Bridge" provides digital skills training for workers in firms that are identified as facing significant digital disruption and have jobs at high risk of automation (OECD, 2019d). In a similar way, Ireland's "Explore" programme, introduced in 2018, could eventually be oriented towards firms in different parts of industry that have a high probability of phasing out certain jobs. At present, Explore is a digital skills training programme targeted towards older manufacturing sector employees. It involves close collaboration with employers, rests on a workplace-relevant professional project, and is tailored to the employee. However, participation is limited to just 500 individuals nationwide. Evaluations are being conducted on the outcomes of initial participants. Insofar as these suggest strong benefits for future job quality and earnings, the authorities should consider expanding this programme, along with other reskilling programmes found to have positive labour market effects, to workers in other sectors where technological change is expected to cause job losses.

In the event that a worker loses their job, re-employment support should be provided as soon as they are notified of the dismissal. However, statutory notice periods are short in Ireland, with employers only needing to give workers two weeks notice ahead of a dismissal if their tenure has been shorter than four years. Regardless, employer cooperation in allowing workers to engage with re-employment services during the notice period should be encouraged.

Some displaced workers will temporarily require financial support in the form of unemployment benefits. The Irish welfare system reduces the risk of people falling into poverty. Although income inequality at market incomes is the highest across the OECD, it is around the OECD average after taxes and transfers are taken into account (OECD, 2018a). Unemployment benefit replacement rates are around the OECD average, but must be combined with effective job search assistance programmes to support displaced 
workers. Past analysis of such programmes in Ireland highlights that they can be totally ineffective if not combined with monitoring of participants and conditionality (McGuinness et al., 2019).

Unemployment benefits should be designed in a way that minimises disincentives for displaced workers to take up new jobs. In Ireland, unemployment benefits are paid at flat rates, meaning that there may be less of a financial incentive for a low-paid worker to take up a new job. Countervailing policy measures to reduce participation tax rates have been introduced. One of them is the Working Family Payment (WFP), formerly the Family Income Supplement, a payment equivalent to $60 \%$ of the difference between a family's weekly income and a specified income limit that depends on family size. The reformed WFP was designed to reduce the disincentives to work, with the payment tapered with any increase in earnings. The authorities should continue to monitor potential work disincentives stemming from the $60 \%$ effective marginal tax rate once family income rises above the specified threshold.

At the same time, the capability of Ireland's public employment services needs to be reoriented to be able to deal with new cohorts of jobseekers, like those displaced due to technological change. Until quite recently, Ireland's public employment services were focused on the large group of unemployed people displaced by the construction downturn and financial crisis. On account of the sustained economic recovery, this group has dwindled, meaning that public employment services should be able to dedicate more resources to easing job transitions of workers displaced by structural change. While the total number of jobseekers has halved since 2009 , the resources dedicated to working age employment supports have quadrupled (Figure 26).

\section{Figure 26. The pool of jobseekers has declined more rapidly than resources devoted to activation}

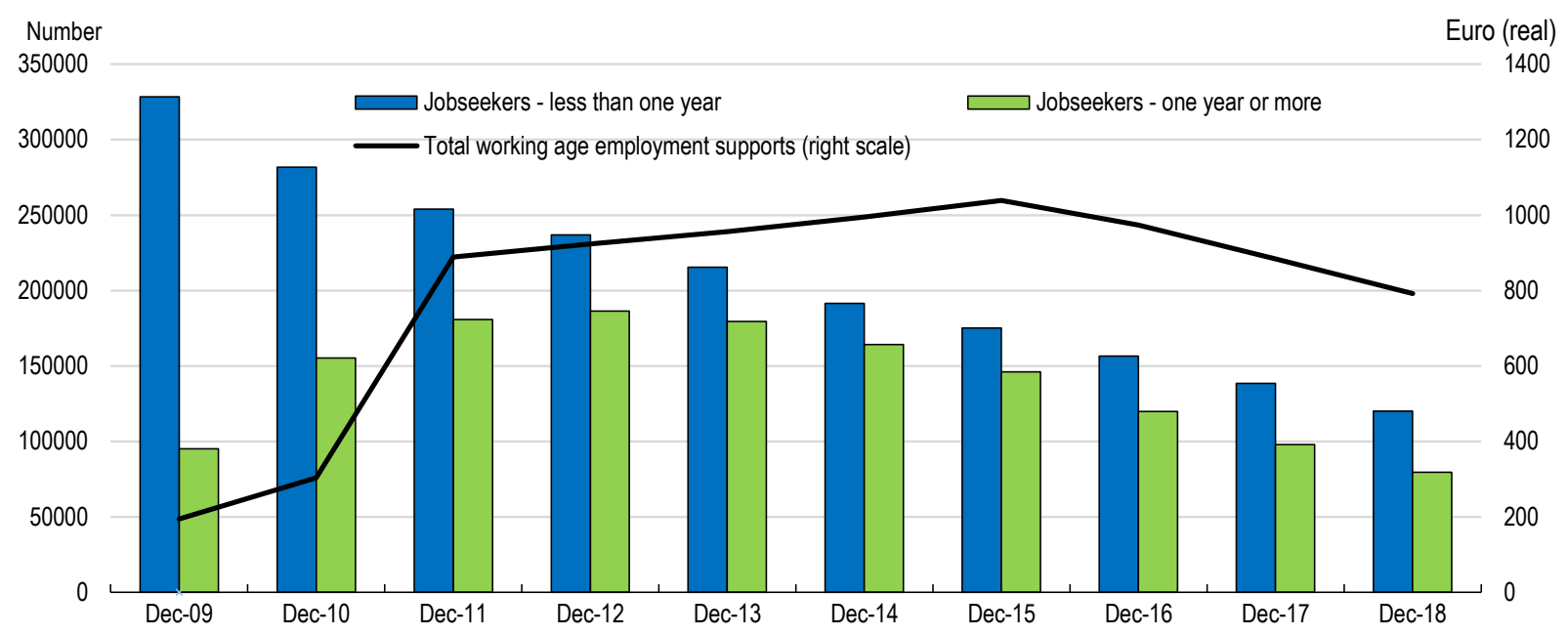

Note: Total working age employment supports are deflated by the CPI to obtain an approximation of the real euro value. Source: CSO, Department of Employment Affairs and Social Protection.

The government undertook a streamlining of benefit receipt and activation services in 2011 to change the manner in which services are delivered to jobseekers. The new system was eventually named Intreo. This included simplification of employment services through one-stop-shop centres and a new case management system. Better monitoring systems were also introduced via compulsory engagement with an Intreo case officer and a new statistical profiling model unveiled to guide activation, engagement and intervention.

An evaluation of the Intreo model in the early years of its operation suggests very weak benefits for activation. There was modest evidence of an employment effect six and nine months after engaging with employment services, but no effect on the likelihood of a claimant entering an education, training or 
employment placement course (Kelly et al., 2019). One of the issues identified was missing data for statistical profiling and miscalculation of the profiling scores. Such scores are useful for segmenting individuals into different categories for engagement with the Department of Employment Affairs and Social Protection. Robust profiling can allow better targeting of those jobseekers most at risk of becoming longterm unemployed and the development of more tailored services for individual jobseekers depending on the employment barriers they face. The authorities should ensure that such profiling systems are performing effectively. In doing so, they should consider incorporating "soft" factors such as job search behaviour, aspirations, preferences, attitudes and life satisfaction in addition to administrative data on the jobseeker. In Germany, including soft factors improved the fit of statistical profiling models considerably (Desiere et al., 2019).

To enable further robust evaluations of the effectiveness of activation programmes, further data collection efforts should be prioritised. Assessing the effectiveness of the programmes and the extent to which the activities undertaken by public employment services are evolving with the changing pattern of jobseekers requires the availability of more detailed data (Lavelle and Callaghan, 2018). Information about the number of referrals, number of engagements, number of workshops, average caseload per case officer, and average frequency of engagement at regular intervals should all be collected and published regularly.

\section{Online platforms will allow more workers to participate in the gig economy}

\section{Growing digital platforms offers both opportunities and challenges}

One of the channels through which new technologies will support workers and create new jobs is through the development of online platforms. Digital technologies significantly lower transaction costs, making it easier for firms to outsource tasks, and for individuals to offer and market their services. The recent rapid rise of "gig economy" platforms that use digital technologies to intermediate labour on a per-task basis offers both opportunities and challenges.

As highlighted in the recent OECD Jobs Strategy, the significant reduction of transaction costs potentially enhances businesses' productivity while lowering barriers for workers to find jobs (OECD, 2018b). The gig economy enables individuals to compete with firms as entrepreneurs, while enjoying flexibility in their work arrangements. In addition, empirical evidence suggests that gig economy platforms can play a role as a labour market buffer during economic downturns (Schwellnus et al., 2019). The Irish authorities should continue to review regulatory settings that may unduly constrain individuals wanting to join the gig economy from doing so. For example, current regulatory settings have impeded new taxi services such as Uber and Lyft that allow private car owners to offer taxi services in some other OECD countries (Deighton-Smith, 2018). Nevertheless, the lines between dependent employment and self-employment are blurred by the emergence of workers focused on a specific task on an on-demand basis. This poses a challenge to conventional labour market institutions, which were based on stable employer-employee relationships. If contract rules and social protection only cover standard workers, firms have an incentive to economise labour costs by shifting work to nonstandard workers who have less protection. In addition, shifting to nonstandard employment can lead to a decline of overall tax revenue if there is a tax differential between types of employment, which is indeed the case for the Irish social insurance system (see below).

These are important considerations for Irish policymakers, as self-employment as a share of total employment was around the OECD average at 15\% in 2018 (Figure 27). A detailed study on contingent employment in Ireland estimated that the proportion of freelance workers steadily increased between 1998 and 2016, even though such workers are a minor component of the labour market, accounting for just $2 \%$ of total employment and $12 \%$ of self-employment (McGuinness et al., 2018). The study projected a continuing rise of the share of freelance workers by one percentage point of total employment by 2025 . 
Figure 27. The share of self-employment in Ireland is around the OECD average

As a share of total employment, in 2018

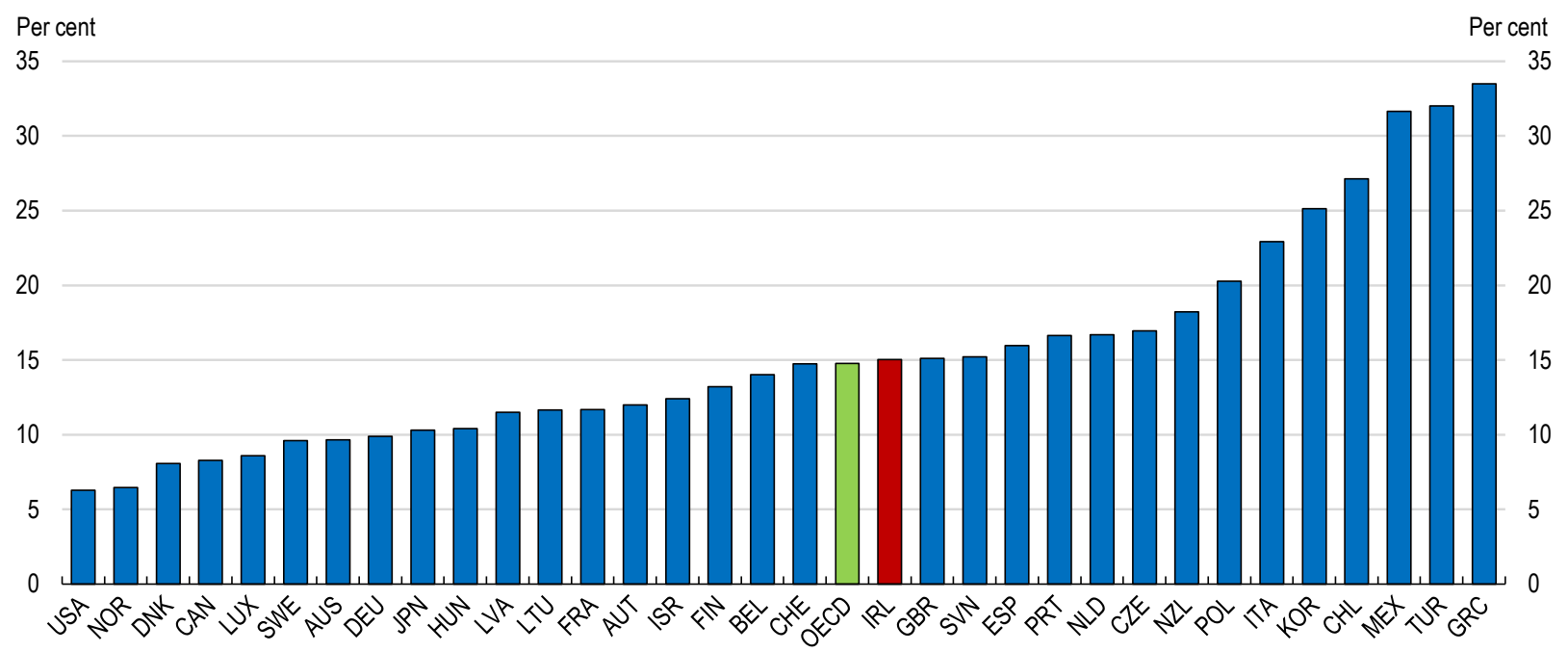

Source: OECD, Labour Force Statistics database.

StatLink 게 SR https://doi.org/10.1787/888934080238

\section{Social protection should be harmonised across different forms of dependent employment}

The emergence of gig workers has added importance to the issue of coverage gaps in social protection between dependent employees and the self-employed, which can distort choices around the form of employment and erode the contribution base of the social protection system. Non-standard workers are included in the definition of "employee" in Irish legislation related to the national minimum wage, antidiscrimination and health and safety. Nevertheless, further harmonisation of social protection schemes across forms of dependent employment, including workers in the "grey zone" (i.e. where workers share some characteristics with dependent employees but are classified as self-employed), is required to close the gaps and ensure that the system covers those most at risk.

The most straightforward way to address this issue would be to add the self-employed into the coverage of existing social protection schemes designed for dependent employees. However, such an approach raises a number of issues. First, it is unclear who should be liable for employer contributions in contributory systems where employers and employees share the contribution burden - the so-called double contribution issue. Second, basing contributions and benefit entitlements on the voluntary tax compliance of self-employed workers may be problematic if such compliance is lacking. This can often be the case for such workers in a context of fluctuating earnings due to payment at irregular intervals, time-lags between work and payment and erratic demand for their services. Third, limiting moral hazard of the self-employed in claiming unemployment benefits can be a challenge, given difficulties in determining the difference between a layoff and voluntary idleness and in monitoring job search effort (OECD, 2018c).

A possible alternative is to create a voluntary social protection scheme for the self-employed. However, this may not be practical, as adverse selection can lead to a spiral of rising premiums and falling coverage. In turn, maintaining a high coverage rate could require heavy public subsidies. Another option would be untying social protection from the employment relationship. While this can be done by granting individual entitlements to tax-financed benefits based on need, it would require a comprehensive means test that may be administratively challenging given the difficulty of calculating the income and assets of the selfemployed. 
Ireland takes the approach of integrating the self-employed into the scheme for dependent employees. The Pay Related Social Insurance (PRSI) allows the self-employed to enrol but with limits on access to benefits. They are only charged employee contributions at the headline rate of $4 \%$ or EUR 500 a year, whichever is larger. Consequently, their average effective contribution rate is around $3.7 \%$, well below the $13 \%$ for dependent employees (when both the employee contribution and the $8.8 \%-11.05 \%$ employer contribution are taken into account). While the PRSI avoids the double contribution issue, it does so at the expense of taxpayers and the arrangements provide a strong incentive for platform operators to shift employment towards self-employment.

In recent years, PRSI benefits have been extended to the self-employed without any increase in their contribution rate. As a result of the extension of the treatment benefit and invalidity pension in 2017 and provision of weekly jobseeker payments to the self-employed in 2019, such workers now have access to $93 \%$ of the PRSI benefits in value terms. To align contributions by the self-employed to their benefit entitlements, it has been suggested that their PRSI contribution rate could be raised by shifting it from an employee to an employer basis (Department of Employment Affairs and Social Protection, 2019).

While shifting the base of the contributions for the self-employed will improve the financial balance of the Social Insurance Fund, the incentive for platform operators to shift their employment to self-employed workers will remain if contributions are fully paid by the workers. In contrast, dependent employment will emerge as the preferred choice for platform workers, as they will be charged employee contributions of $4 \%$ instead of the higher employer contributions. Consequently, employment outcomes can depend on the relative bargaining power between platform operators and workers, which tends to be stronger for the former, given the difficulty of effective enforcement of rules to prevent false classification of de facto dependent employment as self-employment. To make the system neutral to forms of employment in the platform economy, the PRSI contribution for freelance workers could be levied at $4 \%$ with employers also making some contribution based on the scale of work undertaken.

\section{Labour market regulation must evolve with new forms of work}

Extending the coverage of labour market regulations to platform workers in the grey zone is essential to sustain their bargaining position. Rules on work contracts, training provisions, minimum pay and collective bargaining are particularly important.

Rules on transparency of employment contracts, termination of contracts, and mobility of workers are fundamental elements that underpin the bargaining position of workers. The European legislators approved a law in 2019 that applies a set of minimum standards for all workers who work more than 12 hours a month regardless of the form of employment contract. The minimum standards cover:

- Information on essential elements of a work contract to be provided within one week of employment.

- The right to receive compensation in case of late cancellation of the agreed work assignment by the employer.

- A probationary period limited to six months.

- The right to work for other employers, with a ban on exclusivity clauses.

- Access to cost-free mandatory training.

The EU directive has to be transposed into Irish law by 2022. While many elements related to work contracts were already included in the Employment (Miscellaneous Provisions) Act 2018, the directive has a broader definition of workers that covers independent contractors in the gig economy. Although the Act did not include training provisions, Springboard+, a cost-free training programme conceived for the unemployed, was extended in 2017 to include among others the self-employed in certain sectors such as biopharma and medical technology and ICT. Ireland should adopt the EU directive in a way that extends 
the coverage of the existing set of standards to encompass platform workers who are effectively dependent employees.

Rules on minimum pay help increase income security for platform workers in the grey zone. The definition of an employee is generous in Irish national minimum wage legislation. It includes contracts for service, which is the relevant contract for many digital platform workers. Nevertheless, extending the statutory minimum wage that is based on an hourly rate to cover the grey zone workers may be difficult in practice, as such workers are paid per provided service. Provision of piece-rate minimum pay could be an option, though setting the minimum rate can involve a complex task of assessing output per hour for different types of platform workers. This would require cooperation with platform operators, as access to real time data collected by them would be essential to model, understand and demonstrate how demand for individual jobs at given times translates to an hourly rate (United Kingdom Department for Business, Energy \& Industrial Strategy, 2017).

Ensuring the right of collective bargaining would strengthen the bargaining position of platform workers in the grey zone. As in many other OECD countries, the Irish Competition Act had banned collective bargaining of self-employed workers as anti-competitive agreements, decisions and concerted practices. However, the Competition (Amendment) Act 2017 lifted the ban for self-employed voice-over actors, session musicians and freelance journalists. It also provides that a trade union can apply to the Minister for Business, Enterprise and Innovation to permit a collective action of other self-employed workers who fall within certain categories termed 'false self-employed' or 'fully dependent self-employed' workers. While the onus to show that those workers fall within the relevant definition falls on the trade union making the application, the Minister will not approve the application if the collective action would have more than a minimal effect on competition in the relevant market. The impact of the new mechanism is yet to be seen, as no applications have been made so far. The Irish authorities should closely monitor the effectiveness of the recent amendment of the competition law in supporting the bargaining power of false self-employed and fully-dependent self-employed platform workers.

Beyond extending collective bargaining coverage, the bargaining power of platform workers can also be supported by strong enforcement of competition law (OECD, 2019c). Despite rare enforcement in many jurisdictions, some of the competition authorities including US and Japanese enforcers have recently made labour markets the object of their focus (OECD, 2019e). In particular, the Japanese Fair Trade Commission published in 2018 a report on the application of the Antimonopoly Act to trades between independent contractors and their clients. The report provided guidelines on concerted practices including agreements related to rewards and switching jobs as well as on unilateral conduct such as non-compete or exclusive obligations and restrictions on uses of output produced through service provision (Japan Fair Trade Commission, 2018). In addition to improving worker's wellbeing, such measures may benefit the performance of the aggregate business sector. For instance, it may lessen the ability of incumbent firms to restrict worker mobility and, hence, the efficient allocation of labour resources (OECD, 2019c),

\section{Greater residential mobility is needed as the geography of growth evolves}

\section{Housing and infrastructure policies should support agglomeration}

As noted earlier, Dublin has experienced particularly strong growth in economic output over the past decade (Figure 3; Morgenroth, 2018). At the same time, Dublin's share of total employment has risen. Nevertheless, there has been considerable outward migration from Dublin during the period, leading to long commutes (Box 4). This reflects escalating dwelling price premiums (Figure 28) that have deterred potential residents (Garcia-Rodriguez and Morgenroth, 2017). The authorities must ensure that housingrelated policies allow for agglomeration in those geographic areas that have the highest potential for economic growth. 


\section{Figure 28. The Dublin dwelling price premium has been rising}

Premium of dwelling prices in Dublin relative to other Irish areas

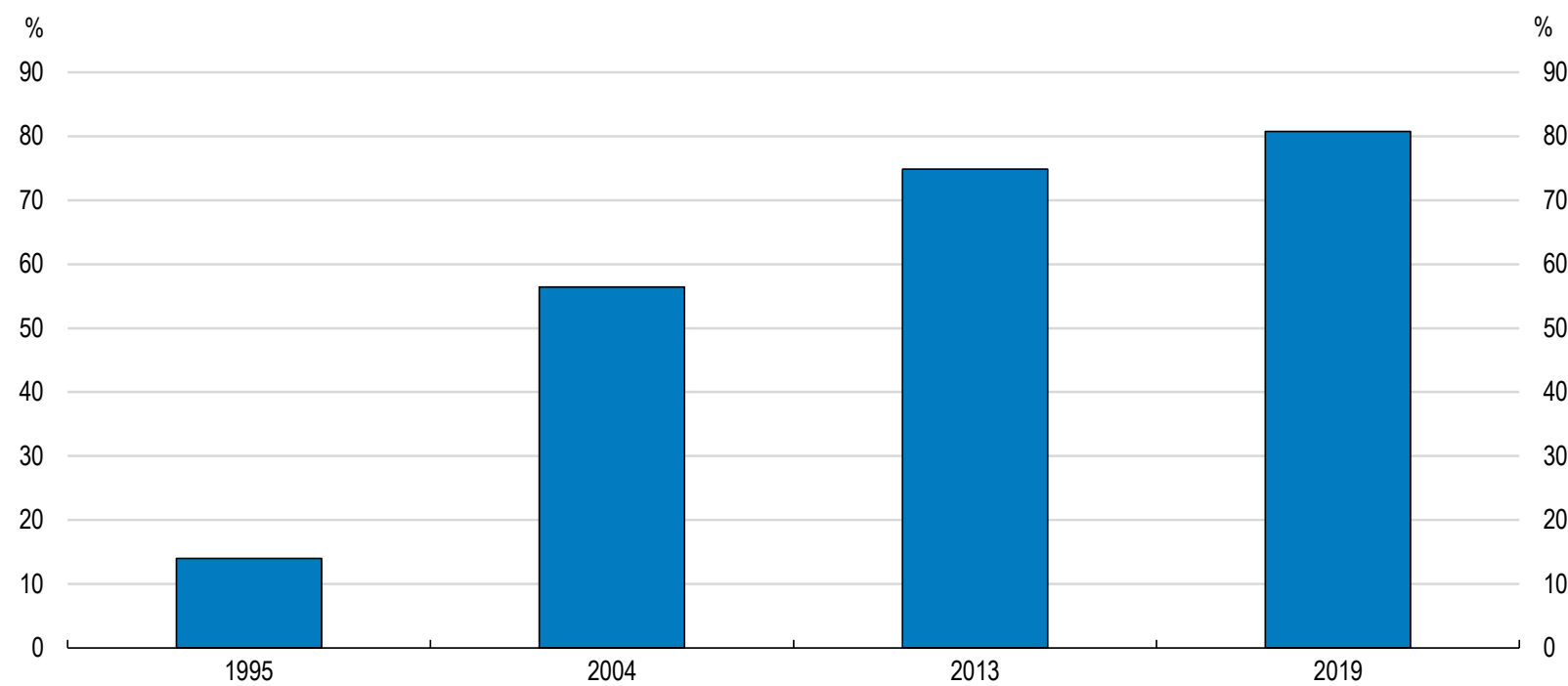

Note: For the 1995 and 2004 bars, the ratio of the price of second-hand dwellings in Dublin to new dwellings in other areas is used. For 2013 and 2019, the data takes account of the mix of properties to make like-for-like comparison between Dublin and other areas.

Source: Lyons and Westmore (2020).

As documented in the 2018 OECD Ireland Economic Survey, the surge in dwelling prices in popular locations, such as Dublin, can be mainly ascribed to low housing supply. Price developments in Dublin have been strongly associated with the availability of housing over the past decade (Figure 31). Along with residential mobility patterns, there have been adverse implications for the wellbeing of some vulnerable groups. The number of homeless adults in Dublin rose by around 50\% between September 2016 and September 2019.

\section{Box 4. Dubliners are moving outside}

The share of Irish people living outside their county of birth has gradually increased in recent decades. This trend has been driven by a rising proportion of those born in Dublin now living in nearby counties (Figure 29).

In 1996, Dublin was home to around 15,000 more people than the total number of Dublin-born people resident in Ireland. This marked Dublin as a destination county for internal migrants. However, by the time of the 2016 Census, the resident population of Dublin was close to 150,000 lower than the total number of the Dublin-born living in Ireland. Census data highlights that Dublin residents increasingly moved away from Dublin over the period, largely to the neighbouring counties of Kildare, Meath and Wicklow.

This net internal outflow from Dublin county even as Irish economic activity became more concentrated in the area has meant that many people now working in Dublin live in other counties. In 2016, the most densely populated $20 \%$ of Irish electoral divisions accounted for $84 \%$ of jobs but just $66 \%$ of homes (Lyons, 2019). The movement out of Dublin has resulted in long commutes for an increasing proportion 
of the population. While around $15 \%$ of the population faced a long commute in 1981 , this had risen to close to $45 \%$ of people by 2016 (Figure 30 ).

\section{Figure 29. Dubliners have been moving to contiguous counties}

Difference between resident population and the population born in county and currently located in Ireland, '000

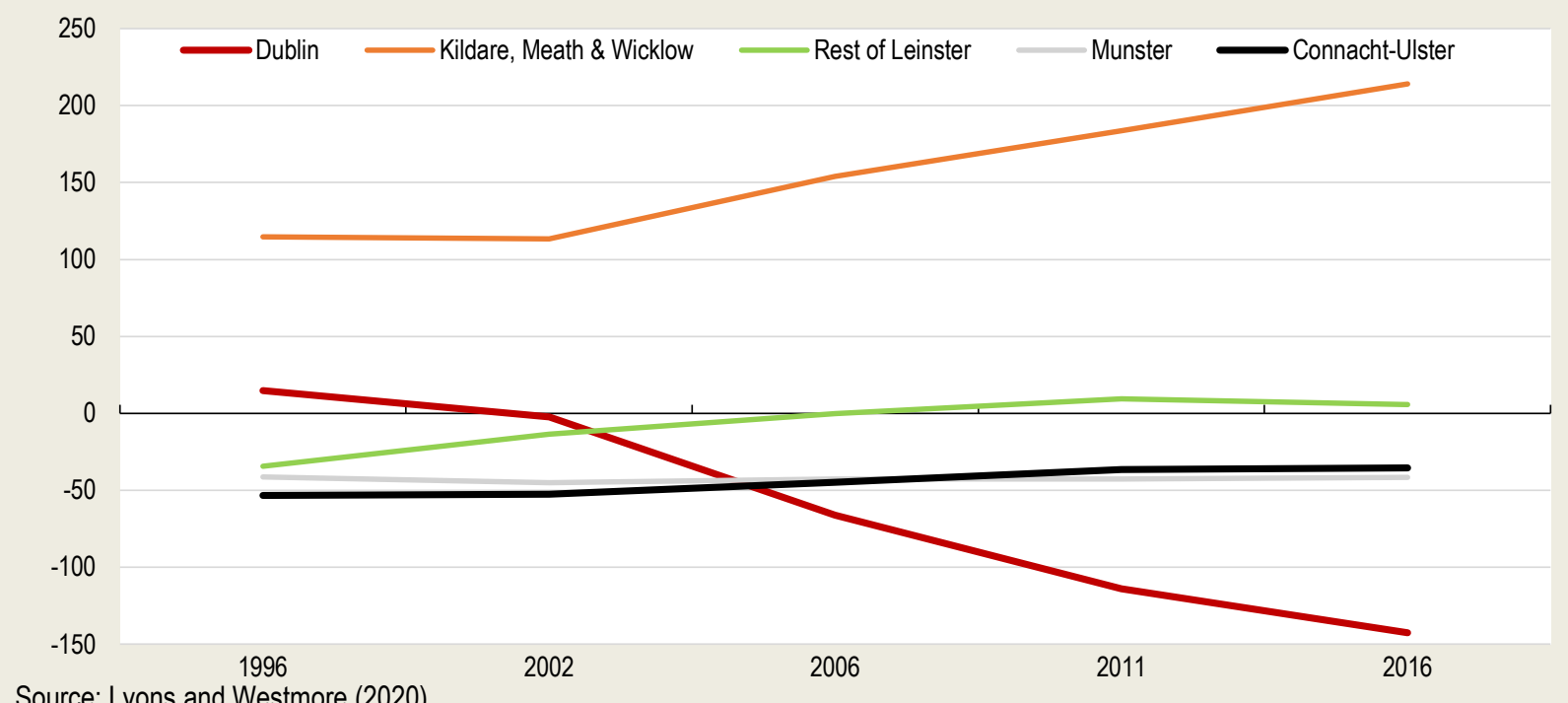

Source: Lyons and Westmore (2020).

StatLink ज्ञात ht htps://doi.org/10.1787/888934080276

\section{Figure 30. Many now face a long commute}

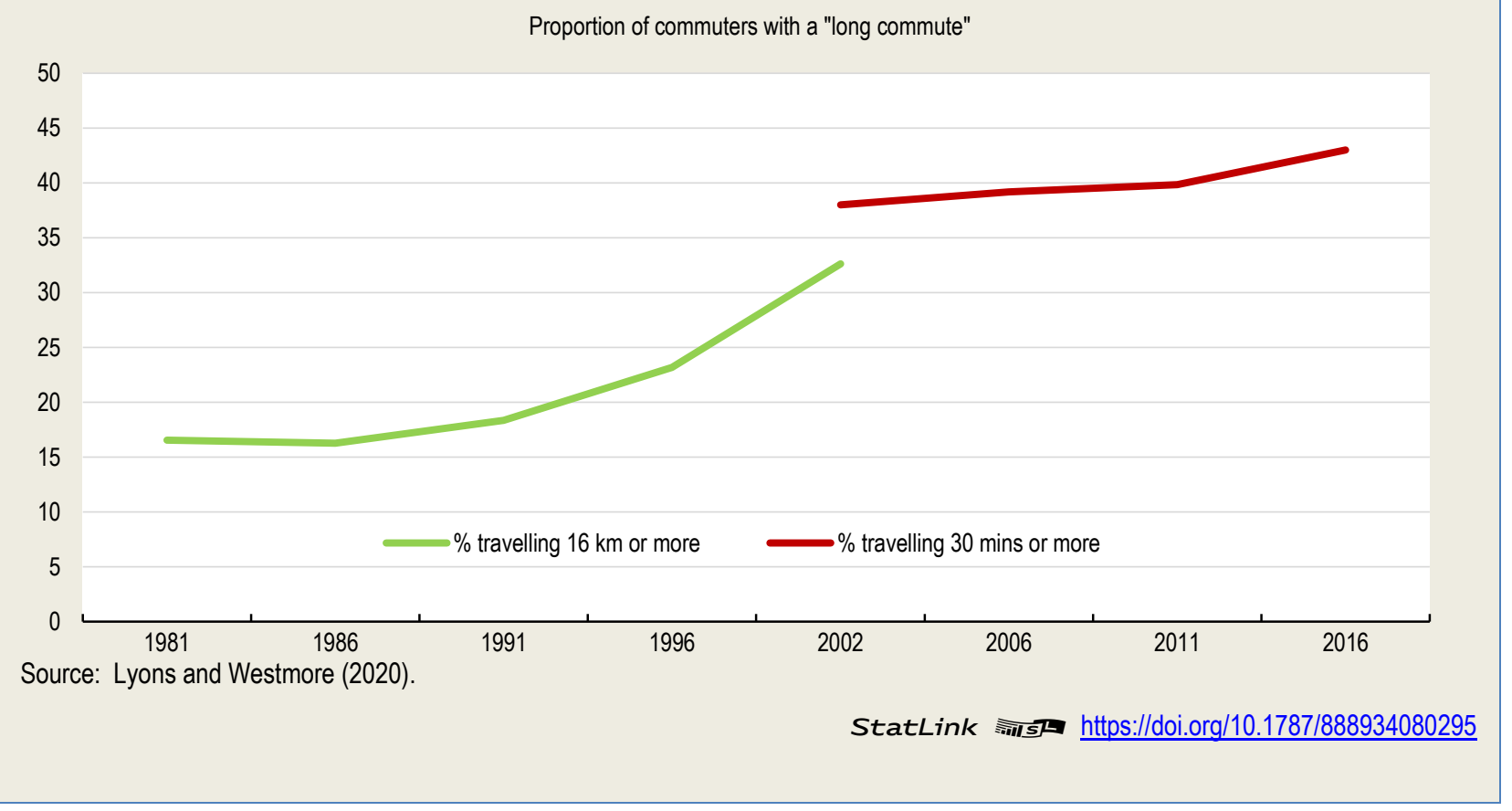

To meet the future needs of the growing Irish population, the capacity of the housing construction sector will need to continue expanding to avoid dwelling supply constraints and a further acceleration in prices (McQuinn, 2018). Key to achieving this will be promoting the efficiency of Ireland's construction sector. Compared with European peers, productivity growth in the Irish construction industry is low, remaining 
around $10 \%$ below the level of labour productivity in 2010 (Government of Ireland, 2019b). It will also be important that appropriately-sized dwellings in the right locations are being built. Just $12 \%$ of dwellings in Ireland are apartments, compared with around half in the European Union at large, even though over half of Irish households comprise just one or two people. In Dublin, less than $30 \%$ of dwellings are apartments, compared with over $60 \%$ in other major cities in Europe.

The dwelling stock in Dublin and other vibrant economic areas should expand to absorb rising numbers of workers without requiring them to endure long commutes. As digital adoption advances, teleworking practices should also be further encouraged; telework rates in Ireland are above the European Union average but well below some countries, such as those in Scandinavia (Eurofound, 2018).

Several policy areas are critical for ensuring flexible dwelling supply in cities, including the availability of local infrastructure, zoning provisions and the extent of brownfield land development. The authorities have presented a long-term strategy for Ireland's development, Ireland 2040, that includes a National Planning Framework which is the overarching spatial development vision for Ireland. Acknowledging that urban sprawl is excessive in Ireland, the framework targets at least $50 \%$ of new future housing to be provided within the existing built-up areas of cities. It also emphasises the need to pro-actively develop infill, brownfield, and publicly-owned sites as well as to make better use of vacant and under-occupied buildings in urban areas. For managing the State's own lands to develop new homes, the Land Development Agency has been established. An independent Office of the Planning Regulator was also set up to ensure that the zoning and planning decisions of local authorities are aligned with the strategy and that planning systems are functioning in a coherent way.

\section{Figure 31 . Dwelling prices reflect supply conditions}

Dwelling stock for sale in Dublin on first day of quarter and subsequent dwelling price change 2006-19

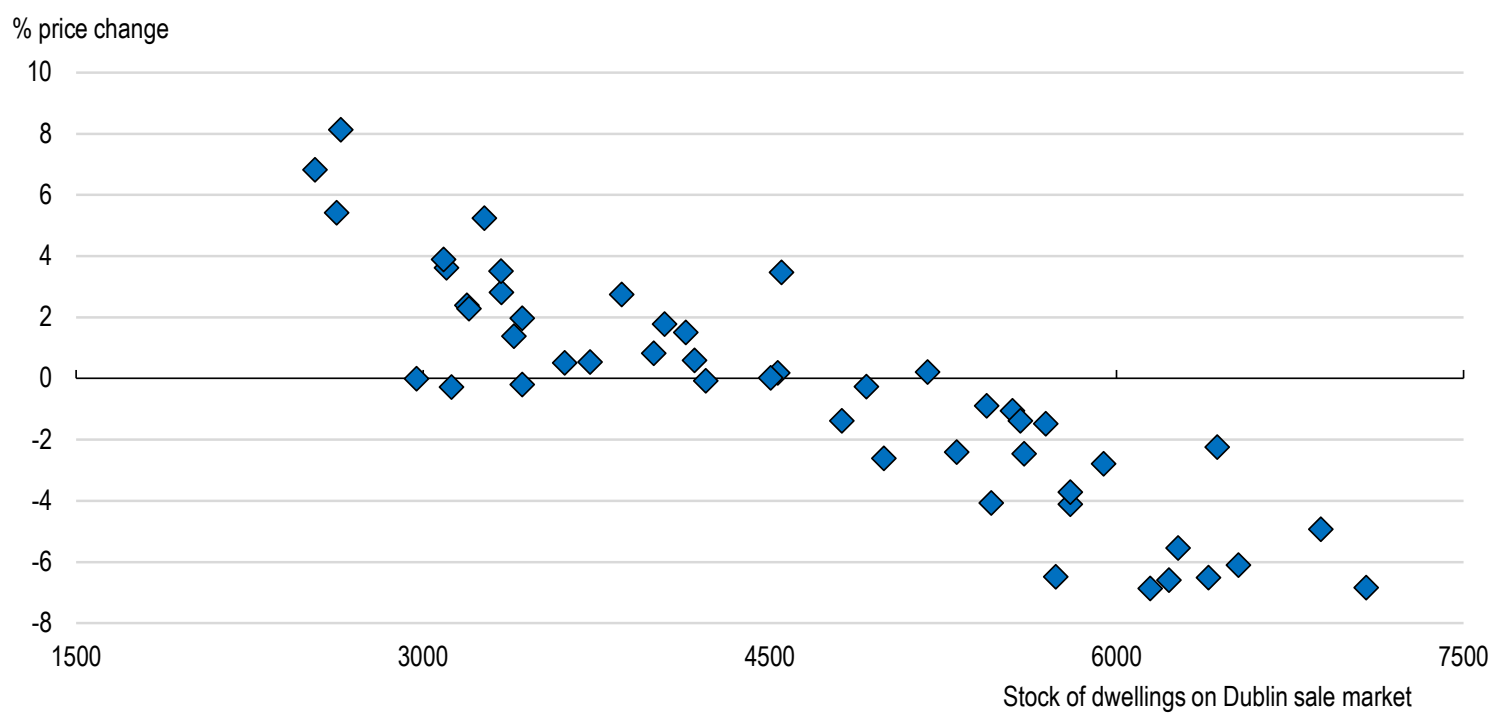

Note: Data are based on the stock of dwellings advertised on the daft.ie online platform.

Source:daft.ie.

StatLink הत्माs https://doi.org/10.1787/888934080314

The new institutions should be coupled with policy settings that are more conducive to new home building. The 2018 OECD Ireland Economic Survey argued that a land tax, levied on the unimproved value of a site, would encourage more efficient land use. With hardly any distortionary effect on the investment decisions of households and businesses (Blöchliger, 2015), such a levy would reduce the hoarding of land in anticipation of capital gains and incentivise governments to regularly reassess the use of publicly-owned 
land. Such a tax could replace some of the existing levies on market property values such as stamp duty and commercial rates that may have notable distortionary impacts on the pattern of firm growth and the reallocation of labour (OECD, 2018a). It would also have broader scope than the existing vacant site levy, as it would capture those sites where structures exist but are not using the land in the most efficient way.

Increasing the residential capacity of new growth areas must be accompanied by initiatives that allow public infrastructure to cope. Dublin roads are some of the most congested in the world (Tom Tom Traffic Index, 2019), underlining the importance of various Ireland 2040 projects that enhance public infrastructure, such as bus corridor upgrades and new and expanded rail lines. The introduction of congestion charging in the busiest areas would promote the use of public transport and the deferral of nonessential trips. At the same time, new modes of shared transport should be encouraged and any regulatory settings that would unnecessarily impede their development reviewed. Modelling suggests substantial reductions in traffic congestion and $\mathrm{CO}_{2}$ emissions from vehicles if $20 \%$ of private car trips in Dublin were replaced by shared transport modes (Box 5). Such a system would depend on widespread technological diffusion though, as services would be coordinated by a digital platform that optimises routing.

\section{Box 5. Digital-based ride sharing in Dublin}

Recent modelling by the International Transport Forum highlights the valuable role that digital-based ride-sharing solutions could play in reducing traffic congestion, $\mathrm{CO}_{2}$ emissions and pollution in Dublin (International Transport Forum, 2018). The study used data from the Census and the Household Travel Survey as well as a web-based survey of potential shared transport users. The results suggest that if $20 \%$ of private car trips in Dublin were replaced with shared modes, emissions and traffic congestion would fall $22 \%$ and $7 \%$ respectively. Shared mobility would also result in better access to opportunities for citizens, especially for inhabitants of areas not well-connected to public transport.

Under such a ride-sharing model, individual private car rides are replaced by rides in shared taxis or shared taxi-buses. These services are modelled to be available on-demand either at the doorstep or at the next street corner. Supply and demand of on-demand services are coordinated by a digital platform which optimises the routing. The modelling results suggest that shared rides could complement existing modes of public transport. Shared rides could feed railway stations, substituting some inefficient bus lines. Survey results suggest that $20 \%$ of car drivers would be willing to switch to shared rides, although this share would be higher if more information about the ride-sharing system or incentives were provided.

The large size of the Greater Dublin area with dispersed demand makes it difficult to provide public transport for the region efficiently. Even for on-demand taxi-buses, demand would be insufficient along some routes. To remain efficient, shared mobility services in these areas could be delivered by using vehicles with fewer seats (i.e. the "shared taxis"). This would still improve mobility at an affordable cost. The environmental benefits of this shift in transport modes could be amplified if shared services were provided using vehicles powered by electricity or, in regions characterised by longer trips, other alternative fuels such as natural gas.

A more ambitious arrangement that shifted all private car travel in Dublin to shared mobility services and the existing rail and light-rail transport network could result in even more dramatic results. Under such a scenario, $\mathrm{CO}_{2}$ emissions from vehicles and traffic congestion would fall $38 \%$ and $37 \%$ respectively.

\section{Regional inequality must be carefully monitored}

An increasing concentration of economic activity in relatively wealthy parts of the country, such as Dublin, is prompting concerns about rising regional inequality. Over the past decade, income disparities across 
Irish regions have risen along with the income gap between the leading (Dublin) and lagging (Border) regions (Figure 32). Projections over the period to 2040 suggest that further economic divergence is in prospect, with jobs growth in Dublin expected to be particularly strong relative to the rest of the country (Morgenroth, 2018). At the same time, potential negative effects from job automation are expected to be mostly felt in towns outside of Dublin, many of which already have relatively low per capita income (Crowley and Doran, 2019; Doyle and Jacobs, 2018).

\section{Figure 32. Regional inequality has been rising}

Measures of regional income disparity

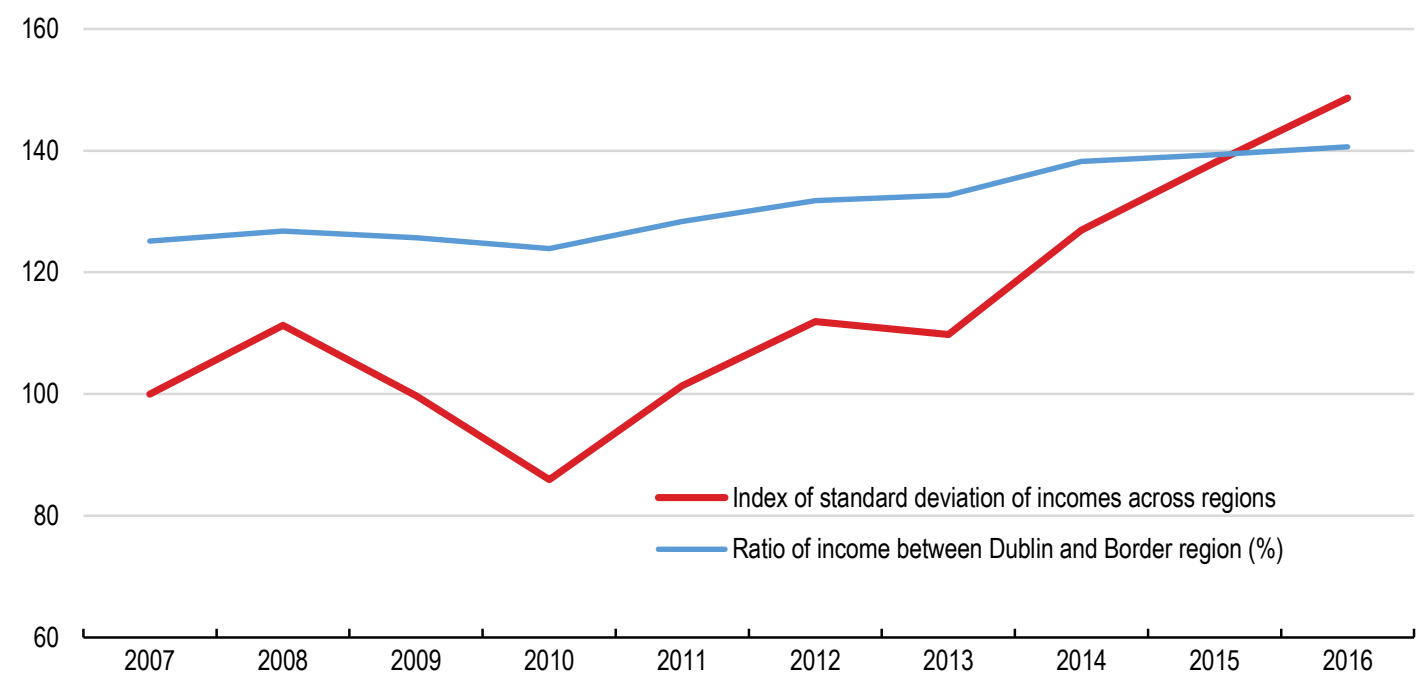

Note: Both measures in the figure are calculated based on disposable income per capita by Irish region. Calculations are based on data from eight Irish regions; Border, Midland, West, Dublin, Mid-East, Mid-West, South-East, South-West. Dublin is the leading region and the Border is the lagging region in each of the years across the 2007-16 period.

Source: CSO, OECD calculations.

StatLink त्ताs https://doi.org/10.1787/888934080333

Looking forward, it is important to encourage economic activity outside of Dublin and the East of Ireland. Second-tier Irish cities are small, at around two-thirds the size of equivalently ranked cities in Denmark (Morgenroth, 2018). Developing scale in the second-tier cities will improve their competitiveness and reduce the cost of providing infrastructure (Hortas Rico and Sole-Olle, 2010). Furthermore, strong economic growth in these areas will have positive spillovers on other counties in the region, making for a strong regional hub around which nearby firms can organise their economic activities. Given budget constraints, public infrastructure spending should be focused on building capacity within second-tier cities rather than spending on motorways and other infrastructure between them that may encourage further urban sprawl.

Some of the Ireland 2040 projects aim at increasing urban density and more compact rural settlements. The specialisation of strong economic poles outside of Dublin should reflect regional endowments and related comparative advantages. Moreover, local stakeholders should be empowered to drive bottom-up initiatives that support local economic development and provided adequate powers and resources to do so. Ireland is now a highly fiscally centralised country; while local government spending accounted for above $30 \%$ of total government spending in the mid-1990s, it now accounts for less than $10 \%$ (Figure 33 ). 


\section{Figure 33. Local governments have little spending power}

Proportion of total government spending undertaken by local government

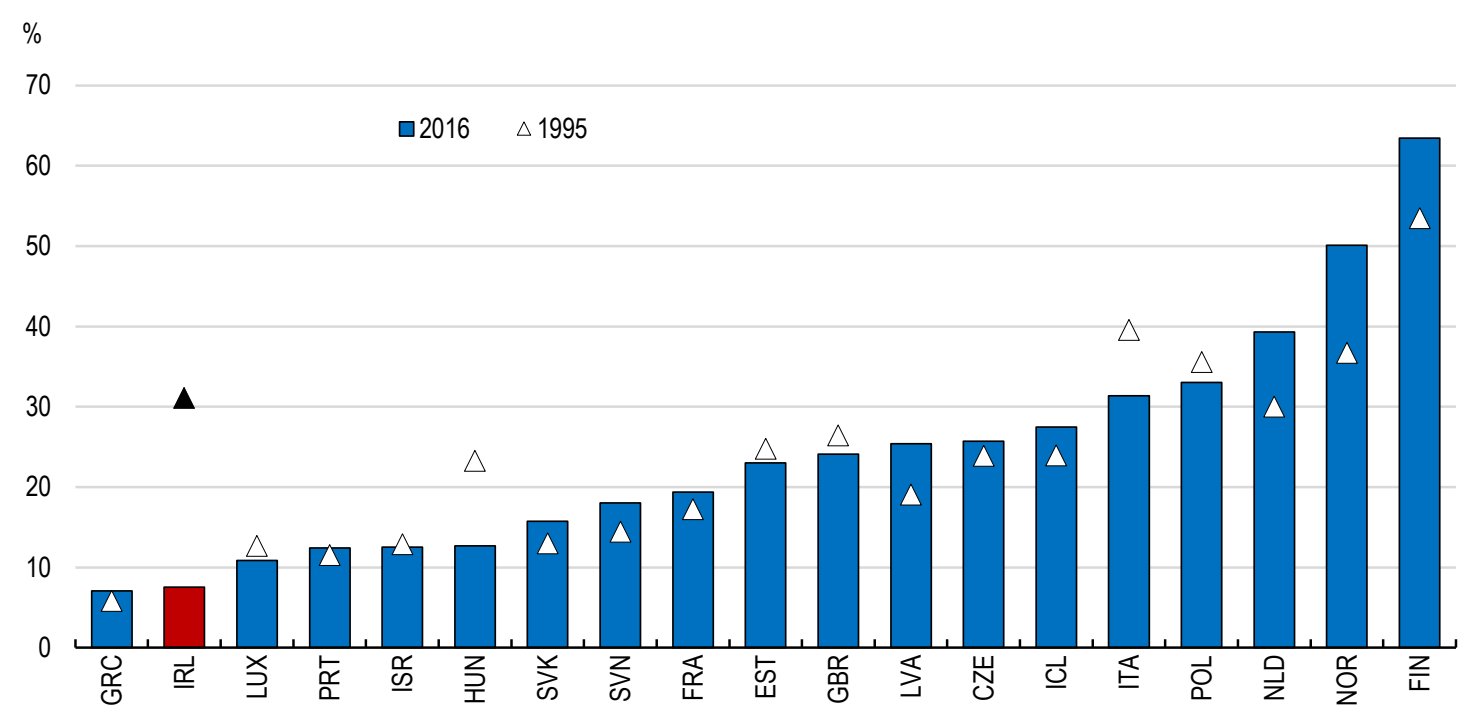

Source: OECD Fiscal Decentralisation database.

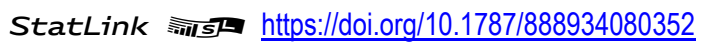

Continuing to promote the accumulation of the right skills in these regions to complement emerging high potential activities has been a recent focus of policymakers. As detailed earlier, Ireland performs well in aligning learning provision to labour market needs. This has been partly achieved through the establishment of nine Regional Skills Fora in 2016 that facilitate cooperation among stakeholders to identify the emerging skill needs in each region and to develop effective learning programmes to meet them. In particular, the institutions have strong dialogue with local businesses for both planning new courses and directing them to relevant training opportunities. A challenge remains convincing employers to release workers to participate in training courses identified as relevant by the Fora. This is especially the case in smaller locally-owned enterprises where the absence of one worker can significantly impact operations. A first step should be to increase the prominence of evaluations, highlighting those programmes with the greatest benefits in terms of firm performance. These should serve to communicate with the management of small businesses.

\section{Competition and digital security policies need to be revisited amid ongoing technological progress}

\section{New technologies may affect competitive dynamics}

Increased technological intensity is changing business models. In turn, market structures are mutating, with implications for competition policy settings. A healthy competitive environment is key for promoting innovation and its diffusion. This process can maximise the benefits of new technologies to firms and citizens, raising aggregate wellbeing. Nevertheless, the emergence of new technologies, especially in the digital sphere, has prompted some concerns about the implications for market power and data protection.

The increasing role of digital technologies has the potential to be competition-enhancing. For instance, the Internet has facilitated the entry and growth of digitally based firms that do not need a physical presence in all markets in which they sell (OECD, 2019a). Nonetheless, there are several unique features of digital markets that may lead to market power, which, if entrenched, could result in higher prices and lower choice 
for consumers. Many digitally-intensive sectors are characterised by: i) substantial network effects in platform markets, meaning that the value to customers of a platform increases with the number of users; ii) high fixed costs and low variable costs, so that there are significant economies of scale and potential financial barriers to entry; and iii) data from users being an important competitive asset for incumbents.

These attributes can create "winner-takes-most" dynamics, whereby a small number of firms obtain dominant positions in digital markets. Even in relatively low-tech industries (e.g. accommodation, food services), the increasing availability of online user reviews tend to shift demand towards a small number of firms. Empirical evidence suggests that enhancing contestability of the platform economy is essential to fully reap the potential benefits from platform growth (Rivares et al., 2019). While online platforms have substantial benefits for consumers and increased market concentration is not necessarily a bad thing, policymakers must ensure that incumbents do not defend dominant positions through anticompetitive conduct. One concerning feature of the Irish economy in this regard has been the divergence in the firm entry rate of those sectors characterised by high digital intensity and the rest of the economy (Figure 34). Between 2013 and 2017, the aggregate firm entry rate (i.e. firm births as a proportion of total active enterprises) rose steadily. This coincided with policy reforms aiming at promoting entrepreneurship, such as the launch of the Capital Gains Tax Entrepreneur Relief Programme, which provided for a reduced capital gains tax rate of $10 \%$ for entrepreneurs, and the introduction of an online facility for business registration. Nevertheless, the firm entry rate for those sectors with a high level of digital intensity stayed basically flat through the period.

\section{Figure 34. The firm entry rate has been weaker in digitally-intensive sectors}

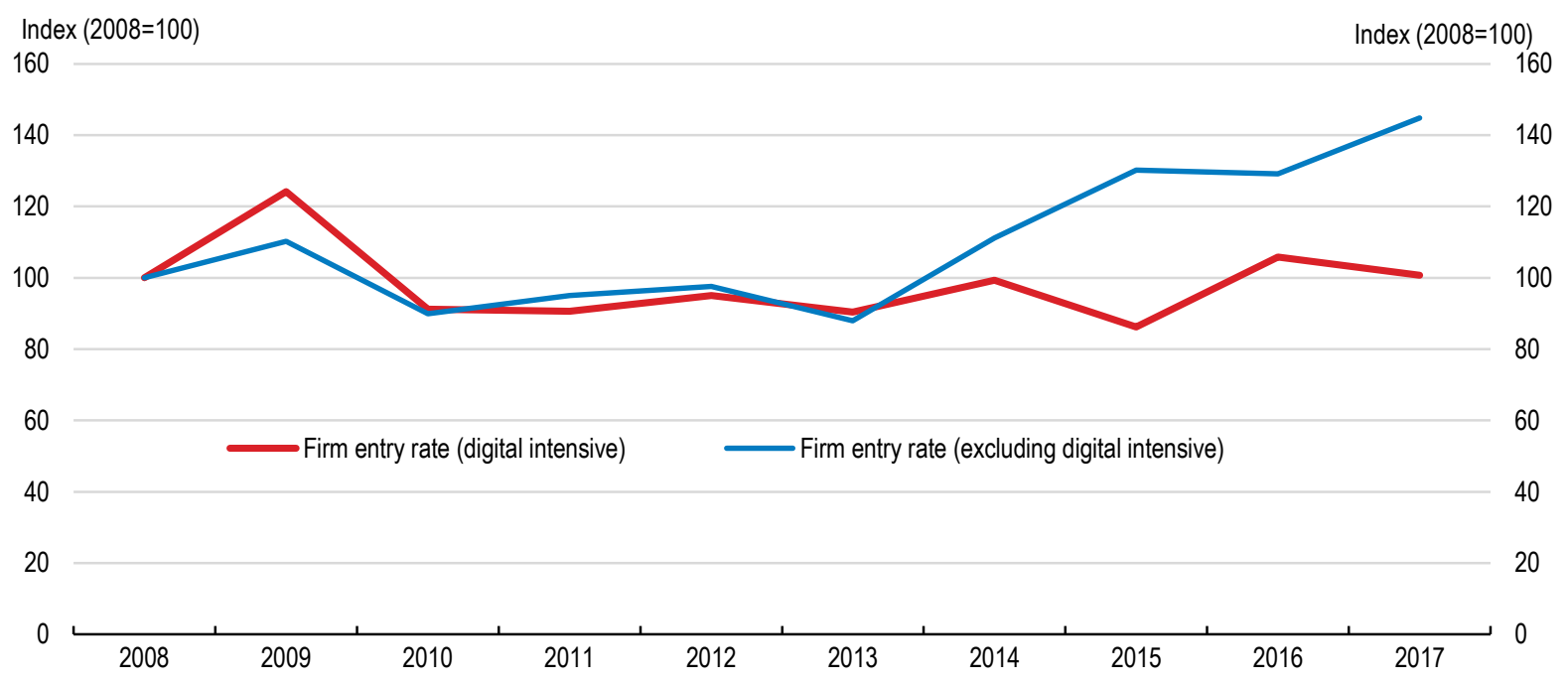

Note: "Digital intensive" sectors are defined using the taxonomy outlined in Calvino and Criscuolo (2019). The firm entry rate is calculated based on the unweighted number of entrants in each period.

Source: CSO, OECD calculations.

A rising number of mergers and acquisitions in the Irish economy could also signal diminishing competitive dynamics in certain markets (Figure 35). In the past five years, the average annual volume of mergers and acquisitions has been over one third higher than in the 2000-2009 period. A high proportion of this activity has been occurring in digitally-intensive sectors, with the volume of mergers and acquisitions in the most technologically-intensive sectors having doubled between 2009 and 2017 (William Fry, 2019). While mergers and acquisitions can benefit productivity through lowering costs or better allowing economies of scale, they may also lead to competition problems, for example when smaller innovative firms are acquired by large incumbents to prevent them from growing into potential competitors. The growth of some of the 
largest global digital companies has been enabled by aggressive merger and acquisition activity: the largest five digital firms worldwide have made over 400 acquisitions in the past decade (United Kingdom Digital Competition Expert Panel, 2019).

\section{Figure 35. Corporate mergers and acquisitions have become more common}

Annual mergers and acquisitions

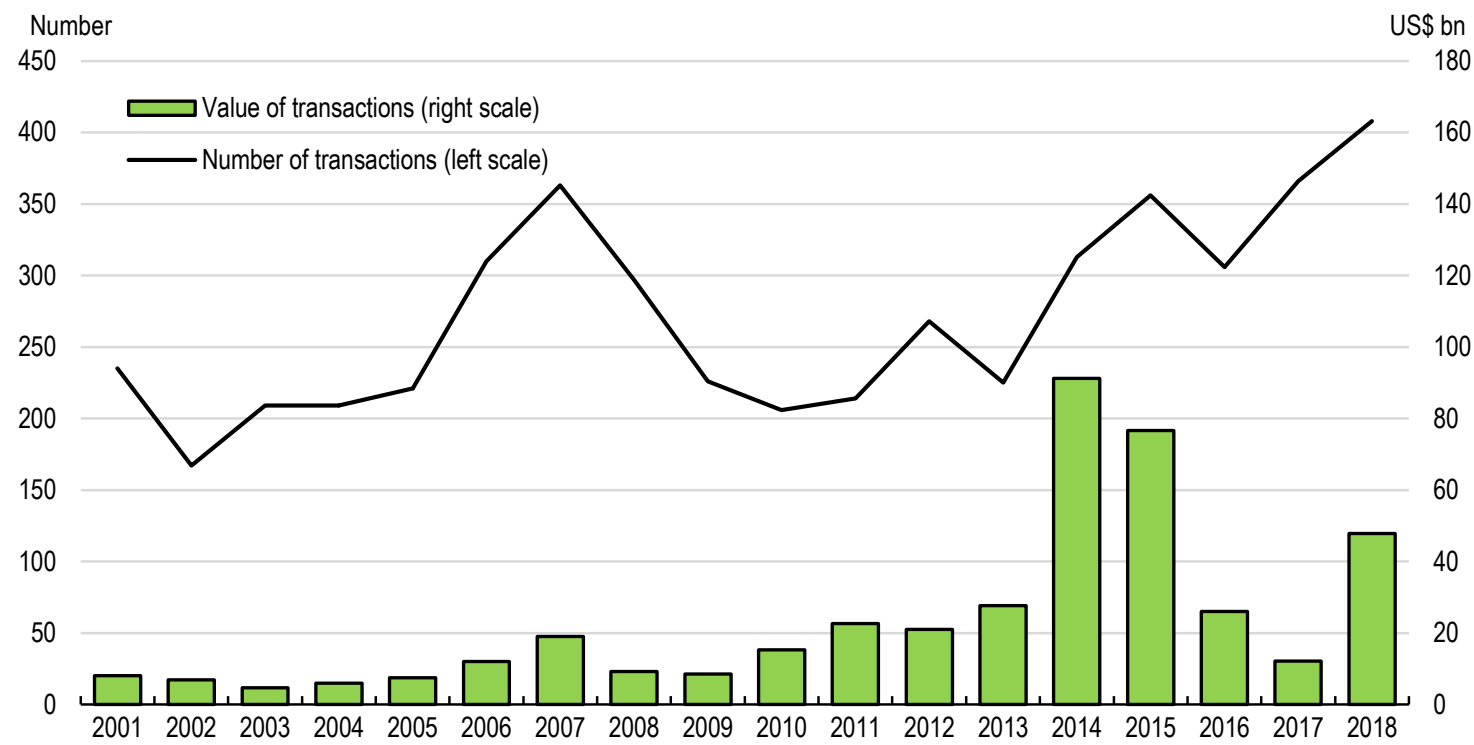

Note: To partially control for inflation in company valuations, the value of transactions is deflated by an index of modified nominal gross national income.

Source: Institute for Mergers, Acquisitions and Alliances.

StatLink जils https://doi.org/10.1787/888934080390

Policymakers must take steps to ensure that any emerging risks for competition resulting from new technologies are carefully managed. The activities of competition authorities will be important, especially by ensuring that enforcement powers are adequate to deal with the changing landscape. Unlike relevant authorities in most European countries, the Irish Competition and Consumer Protection Commission does not have the power to fine companies for non-criminal breaches of competition law. Allowing the imposition of financial sanctions would align with the recent directive of the European Union (European Union, 2019). However, transposing the directive may be complicated by the prohibition in the Irish constitution of penalties in civil cases that are essentially identified with criminal charges. Insofar as the constitution allows it, sanctioning powers against non-criminal breaches of competition law should be provided to the Irish Competition and Consumer Protection Commission. Doing so will further deter businesses considering anticompetitive behaviour.

There may also be a case for the competition authority considering additional merger notification thresholds to ensure that anticompetitive acquisitions do not go unscrutinised. In response to the acquisition activity of large digital firms, Germany and Austria are experimenting with merger notification thresholds based on transaction value rather than the revenue of the participating firms. This seeks to capture mergers or acquisitions of small high-potential firms that may be in the early years of operation and do not have substantial revenues.

In addition, the assessment of mergers in dynamic digital markets will require the Competition and Consumer Protection Commission to focus on innovation, non-price competition (particularly when products are offered to consumers at a zero price) and the multi-sided nature of digital platform markets 
(OECD, 2018d). This can lead to significant technical challenges and may require the adaptation of analytical tools. Ensuring sufficient economic expertise within the Commission will be crucial.

It may be that the traditional regulatory framework needs to be revisited in light of emerging digital technologies. New regulatory functions or institutions may even be needed to govern these markets in the most efficient way. The pace of antitrust enforcement may also need to be accelerated given the speed with which digital markets evolve, for example through the use of interim measures. Recent government reports on digital competition policy in Australia, the EU and the United Kingdom have identified a range of additional measures to address the competition issues arising from digitalisation. These include stronger enforcement procedures, such as shifting the evidentiary burden to dominant firms in some cases. Further, regulatory measures could enhance competition in digital markets, for example with rules promoting data mobility and open standards (Box 6).

The Irish authorities should continue to monitor the impact on competition of the diffusion of new technologies. Doing so will allow Ireland to play an ongoing role in developing new regulations at EU level and to identify the need for any necessary domestic policy adjustments in addition to the EU standards. To enable this, the competition authority should be active in conducting relevant analysis and participating in market studies that help illuminate any competition problems in Ireland's digital markets that may be arising outside the framework of enforcement action.

\section{Box 6. The United Kingdom Digital Competition Expert Panel Report}

In March 2019, the Digital Competition Expert Panel in the United Kingdom published its report "Unlocking digital competition". The group was appointed by HM Treasury to examine the potential opportunities and challenges the emerging digital economy may pose for competition.

A key recommendation from the review was for the establishment of a digital markets unit. By nature, digital markets can be very dynamic, and harmful behaviours in these markets very complex (both to assess and remedy) and unique to the specific situation. In this context, in addition to traditional competition policy, a regulatory body that has dedicated expertise on digital matters and capacity to swiftly investigate and resolve matters may be needed.

The report envisaged that the unit would have three main functions backed by new legislation. It would:

1. Develop a code of conduct.

This would be created in coordination with all stakeholders in digital markets, but only apply to companies with "strategic market status", to avoid excessive regulatory burden. Large digital platforms, for example, would be covered. The code would be formed around a set of core principles that ensured business users are: i) provided access to designated platforms on a fair, consistent and transparent basis; ii) provided with prominence on designated platforms on a fair, consistent and transparent basis (e.g. in instances where a platform contains a search function that generates results); iii) not unfairly restricted or penalised as a result of utilising alternative platforms or routes to market.

2. Enable greater personal data mobility and systems with open standards.

It is desirable for consumers to be able to request that the data a business holds relating to them be directly shared between a business and third party. This would enable consumers to switch more easily between digital platforms, manage their data held across digital platforms in one place or allow them to make a choice to share their data in exchange for some benefit. The extent of personal data mobility could involve any such data, though careful consideration is warranted where businesses have invested in collecting observed or inferred data. 
Systems with open standards are those built using technical specifications that are agreed in common and freely available. They should enable interoperability, compatibility and consistency across services. Such standards can enable innovators to build new propositions which compete directly with existing ones or ancillary services based on existing systems, bringing about a host of new opportunities. An example of a closed system is many internetbased messaging services whereby users can only message their contacts who have accounts with the same messaging provider. The digital markets unit should be given powers to require systems to build on open standards, if it determines that approach to be best.

3. Use data openness as a tool to promote competition.

Greater data openness could reduce barriers to entry into digital markets and promote innovations by third parties. Nevertheless, powers that allowed the digital markets unit to require the opening up of a part of a business's legitimately obtained data to potential competitors should be exercised with caution. Doing so would need to be coupled with privacy safeguards and consideration of the impact on incentives of investment in future data collection and management by businesses.

Source: United Kingdom Digital Competition Expert Panel (2019).

\section{Buttressing digital security is an ongoing priority}

Data have become a core input to innovation and policies need to evolve to address data access issues. A general principle is that data access policies should ensure the broadest possible access to data and knowledge so as to favour competition and innovation, while respecting constraints regarding data privacy, ethical considerations, economic costs and benefits, and intellectual property rights (OECD, 2019f). The potential of the digital economy can only be realised if participants, including consumers, trust that their data will be responsibly safeguarded.

In May 2018, the EU General Data Protection Regulation came into effect. The regulation harmonises data protection legislation in the European Economic Area countries and gives greater rights to individuals in determining how their data is used. The regulation requires that data be collected and processed transparently, be held for the minimum time necessary and gives a data subject the right to request that a data controller erases their personal data.

Although the General Data Protection Regulation legislation enshrines some data portability rights, it does not have explicit requirements for parties to develop technical standards to facilitate data transmission and there is no requirement that data portability be possible on a continuous, rather than discrete, basis. The authorities should consider introducing these additional requirements.

The Irish authorities are at the centre of enforcing the EU General Data Protection Regulation. This is because the regulation stipulates that the lead regulator be the data protection commission in the country where the relevant firm has their data controller. Given that the European headquarters of many of the largest technology companies in the world are in Ireland, the Irish Data Protection Commission now has a significantly enhanced responsibility in enforcing the proper use of the data of individuals from across Europe. This duty should be diligently performed. The Commission has already expanded in light of these new responsibilities, but it must continue to be allocated adequate resources to properly enforce the legislation.

Digital security is also becoming more important as the value and volume of data rise. Digital security incidents, for both organisations and individuals, are increasing in sophistication and impact (OECD, 2018e). The constantly evolving nature of digital ecosystems means these risks cannot be eliminated entirely, but an institutional setting should be established in which they are best managed. 
The Irish government published a Cyber Security Strategy in 2015, which was updated in 2019. This was designed to build the capability of the National Cyber Security Centre, the primary cyber security authority in the State. In recent years, the centre's capacity and resources have expanded and its roles have been formally established in law. A key challenge remains the availability of workers with strong cyber security skills that can effectively monitor and enforce actions against new risks. The Cyber Security Skills Initiative was launched in October 2018 to address such skills gaps. The programme will provide 5,000 IT professionals across 4,000 companies with training in cybersecurity. This is a worthwhile initiative that may be needed on an ongoing basis as long as there is a shortfall of cyber security skills. Many of the benefits of reducing cyber security risks will accrue to businesses, so the financing of such courses should be shared between the public and private sectors.

\section{Tax policy settings also need updating}

As technological change enables new business models to develop, taxation systems will need to adjust accordingly. New technologies may bring significant benefits to tax administrations. An increased propensity for previously unreported economic activities to take place via online platforms could help in detecting under-reporting, tax evasion or tax fraud. This is especially the case when combined with advances in data storage capacity and the analytical techniques of taxation agencies (OECD, 2019g). Taxpayers can also benefit, through the introduction of online channels of communication and the prefilling of tax returns. For many years Ireland has had a Revenue Online Service for taxpayers, which should continue to integrate new features that become possible with further technological advances.

Concurrently, new technologies create tax policy challenges. Digital technologies may enable enterprises to be active in an economy without having a significant physical presence. This raises important issues related to the allocation of taxing rights between jurisdictions and the determination of the relevant share of multinational profits subject to tax in a given place. Furthermore, tax administrations may struggle to identify the parties or payment amounts of transactions undertaken via online peer-to-peer platforms when the platform operator is not located in the same tax jurisdiction.

To confront these challenges, international tax policy coordination is essential. The OECD recently proposed new arrangements to ensure large and highly profitable multinational enterprises, including digital companies, pay tax wherever they have significant consumer-facing activities and generate their profits. Under the proposal, countries would have some power to tax companies that operate within the domestic economy, irrespective of whether they have a physical presence. After a period of stakeholder consultation on the proposal, the aim is for a consensus-based solution to be ready for political agreement in the first half of 2020 (OECD, 2019h). Ireland should continue to be an active participant in these multilateral discussions given the many multinational enterprises that have a significant physical presence in the country. 


\section{Box 7. Recommended policies for promoting inclusive technological diffusion}

\section{Promoting further technological diffusion to boost productivity growth}

- Monitor business licensing requirements and the systems that facilitate them, including by linking more licensing procedures with the Integrated License Application Service.

- Introduce the "digital postbox" system and develop new digital government services that improve citizens' interactions with public administration.

- Introduce inter-professional cooperation in the provision of legal services.

- Help overcome market failures by broadening and focusing public lending programmes on small and medium enterprises with a high share of intangible assets and innovative business models.

- Encourage the emergence of alternative online sources of finance, while paying close attention to consequences for financial stability and competitive dynamics in the lending sector.

\section{Accumulating the right skills for a technologically rich world}

- Enhance financial assistance for training programmes for young workers. More actively establish and promote distance learning programmes.

- Couple adequate public financial support for childcare with measures to expand childcare capacity.

- Consider introducing a cost-reimbursement element to the National Training Fund levy, whereby firms pay a levy but can claim back incurred training costs.

\section{Supporting workers to transition to jobs in new growth areas}

- Publicly fund training programmes tailored to employees in enterprises with a high probability of dismissing workers in the near future due to technological change.

- Ensure statistical profile models of welfare recipients are using complete and updated data.

- Begin publishing information about job search assistance activities such as the number of referrals, number of engagements, number of workshops, average caseload per case officer.

\section{Seizing the opportunities and addressing the challenges of the gig economy}

- Require those freelance platform workers who are effectively dependent employees to pay a Pay-Related Social Insurance premium equivalent to that paid by dependent employees and introduce an employer contribution.

- Prioritise implementation of the EU Directive 2019/1152 to extend the coverage of minimum standards for workers and cost-free training to all forms of dependent employment.

- Consider reinforcing the minimum pay rules for platform workers in the grey zone who perform specific tasks on an on-demand basis, including the introduction of a piece-rate minimum pay.

- Ensure the right to collective bargaining for certain categories of self-employed platform workers (i.e. fully-dependent self-employed and false self-employed) by closely monitoring the impact of the recent competition law amendment. 


\section{Facilitating residential mobility to accommodate structural changes}

- Replace some of the existing property levies, such as stamp duty, with a recurrent land tax to encourage more efficient land use.

- Continue to invest in public transport, and consider further promoting digital-based ride sharing and the introduction of congestion charging.

Updating competition and data security policies in response to the emergence of new technologies

- Give the Irish Competition and Consumer Protection Commission adequate enforcement powers to fight anti-competitive behaviour, including the capacity to impose sufficient penalties on competition law infringements to ensure a deterrent effect.

- Consider alternative merger notification thresholds such as those based on transaction value rather than the revenue of the participating firms.

- Ensure that the Irish Data Protection Commission continues to have adequate resources to rigorously enforce the EU General Data Protection Regulation. 


\section{References}

Andrews, D., G. Nicoletti, and C. Timilotis (2018), "Digital technology diffusion: A matter of capabilities, incentives or both?", OECD Economics Department Working Papers, No. 1476, OECD Publishing.

Andrews, D. and C. Criscuolo (2013), "Knowledge-based capital, innovation and resource allocation", OECD Economics Department Working Papers, No. 1046.

Bassanini, A. and S. Scarpetta (2002), "Growth, technological changes and ICT diffusion: recent evidence from OECD countries", Oxford Review of Economic Policy, Vol. 18, No. 3.

Blöchliger, H. (2015), "Reforming the tax on immovable property: taking care of the unloved", OECD Economics Department Working Papers, No. 1205, OECD Publishing, Paris.

Bourke, J. and S. Roper (2019), "Micro-businesses in Ireland: from ambition to innovation", Cork University Business School.

Calvino, F. and C. Criscuolo (2019), "Business dynamics and digitalisation", OECD Science, Technology and Industry Policy Papers, No. 62, OECD Publishing, Paris.

Card, D., J. Kluve, and A. Weber (2015), "What works? A meta-analysis of recent active labor market program evaluations", NBER Working Paper, No. 21431.

Central Bank of Ireland (2019), SME Market Report 2019, Dublin.

Corrado, C., J. Haskel, C, Jona-Lasinio, and M. Iommi (2016). "Intangible investment in the EU and US before and since the Great Recession and its contribution to productivity growth", in Investment and Investment Finance in Europe 2016, Chapter 2, pp. 73-102, European Investment Bank.

Crowley, F. and J. Doran (2019), "Automation and Irish towns; who's most at risk", Spatial and Regional Economics Research Centre Working Paper, No. 2019-1, Cork.

Desiere, S., K. Langenbucher and L. Struyven (2019), "Statistical profiling in employment services: an international comparison", OECD Social, Employment and Migration Working Papers, No. 224, OECD Publishing, Paris.

Department of Employment Affairs and Social Protection (2019), Pay Related Social Insurance, Tax Strategy Group Papers, 06/19, Department of Employment Affairs and Social Protection Tax Strategy Group, July.

Doyle, E. and L. Jacobs (2018), "Automation and occupations: a comparative analysis of the impact of automation on occupations in Ireland", Irish Government Economic and Evaluation Service, Technical Paper, Dublin.

Duval, R., M. Eris and D. Furceri (2011), "The effects of downturns on labour force participation: evidence and causes", OECD Economics Department Working Papers, No. 875, OECD Publishing, Paris.

Eurofound (2018), Living and working in Europe 2017, Publications Office of the European Union, Luxembourg.

European Centre for the Development of Vocational Training (2012), "Payback clauses in Europe: Supporting company investment in training, Final report", European Centre for the Development of Vocational Training Research Paper, No. 23, Publication Office of the European Union, Luxembourg.

European Commission (2019), Draft Joint Employment Report, 2019 European Semester: Autumn Package, Brussels.

European Investment Bank (2019a), The Digitalisation of Small and Medium Enterprises in Ireland: Models for Financing Digital Projects, Innovation Finance Advisory, Luxembourg.

European Investment Bank (2019b), European Investment Bank Investment Report 2018/2019: Retooling Europe's Economy. European Investment Bank.

European Union (2019), "Directive (EU) 2019/1 to empower the competition authorities of the member 
states to be more effective enforcers and to ensure the proper functioning of the internal market", Official Journal of the European Union.

Frey, C.B. and M.A. Osborne (2017), "The future of employment: how susceptible are jobs to computerisation?", Technological Forecasting and Social Change, Vol. 114.

Gal, P., G. Nicoletti, T. Renault, S. Sorbe and C. Timiliotis (2019), "Digitalisation and productivity: in search of the holy grail - firm-level empirical evidence from EU countries", OECD Economics Department Working Papers, No. 1533, OECD Publishing, Paris.

Garcia-Rodriguez, A. and E. Morgenroth (2017), "Internal migration and housing cycles", paper presented at the European Regional Science Association Congress, Groningen, Netherlands.

Government of Ireland (2019a), Future Jobs Ireland 2019: preparing now for tomorrow's economy, Dublin.

Government of Ireland (2019b), "Construction sector performance and prospects 2019", Project Ireland 2040, Investment Projects and Programmes Office, Dublin.

Hortas Rico, M. and A. Sole-Olle (2010), "Does urban sprawl increase the costs of providing local public services? Evidence from Spanish municipalities”, Urban Studies, Vol. 47, No. 7.

IBEC (2017), Response to proposed Exchequer-Employer Investment Mechanism for HE and FET, Irish Business and Employers Confederation.

International Transport Forum (2018), "Shared mobility simulations for Dublin", International Transport Forum Policy Papers, No. 58, Paris.

Irish Competition and Consumer Protection Commission (2019), Annual Report on Competition Policy Developments in Ireland, Submission to the OECD Competition Committee, June.

Higher Education Authority (2019), Irish National Employer Survey: Final Report, January.

Japan Fair Trade Commission, (2018), Report of the Study Group on Human Resource and Competition Policy, Japan Fair Trade Commission Competition Policy Research Center, February.

Kelly, E., S. McGuinness, P. Redmond, M. Savage and J.R. Walsh (2019), "An initial evaluation of the effectiveness of Intreo activation reforms", ESRI Research Series, No. 81.

Lavelle, O. and N. Callaghan (2018), Public Employment Services - Mapping Activation, Spending Review 2018, Department of Public Expenditure and Reform.

Lilien, D (1982), "Sectoral shifts and cyclical unemployment", Journal of Political Economy, Vol. 90, No. 4.

Lyons, R. and B. Westmore (2020), "Residential mobility in Ireland", OECD Economics Department Working Paper, forthcoming.

Morgenroth, E.L.W. (2018), "Prospects for Irish regions and counties: scenarios and implications", Research Series, Economic and Social Research Institute, No. 70.

McGuiness, S., A. Bergin, C. Keane, and J. Delaney (2018), "Measuring contingent employment in Ireland", ESRI Research Series, No. 74, Economic and Social Research Institute, Dublin.

McGuinness, P.J. O'Connell and E. Kelly (2019), "Carrots, no stick, no driver: the employment impact of job search assistance in a regime with minimal monitoring and sanctions", Journal of Labor Research, Vol. 40, No. 2.

McNaboe, J., N. Burke, D. Walls, N. Condon, A. M. Hogan, C. Shally, and I. Wowczko (2018), National Skills Bulletin 2018, December, Further Education and Training Authority (SOLAS).

McQuinn, K (2018), "Capacity constraints in the Irish economy? A partial equilibrium approach", ESRI Research Note, No. 0401.

National Competitiveness Council (2018), Ireland's Competitiveness Challenge 2018, Dublin.

Nedelkoska, L. and G. Quintini (2018), "Automation, skills use and training”, OECD Social, Employment 
and Migration Working Papers, No. 202, OECD Publishing, Paris.

OECD (2020a), FDI Qualities and Impacts in Ireland, Directorate for Financial and Enterprise Affairs, forthcoming.

OECD (2020b), OECD Economic Surveys: Ireland 2020, OECD Publishing, Paris.

OECD (2019a), Going Digital: Shaping Policies, Improving Lives, OECD Publishing, Paris.

OECD (2019b), SME and entrepreneurship policy in Ireland, OECD Publishing, Paris.

OECD (2019c), The Future of Work: OECD Employment Outlook 2019, OECD Publishing, Paris.

OECD (2019d), OECD Economic Surveys: Luxembourg 2019, OECD Publishing, Paris.

OECD (2019e), "Competition concerns in labour markets", Background note by the Secretariat,

Directorate for Financial and Enterprise Affairs Committee, June.

OECD (2019f), Digital Innovation: Seizing Policy Opportunities, OECD Publishing, Paris.

OECD (2019g) "Tax and digitalisation", OECD Going Digital Policy Note, OECD, Paris.

OECD (2019h), "Secretariat proposal for a 'unified approach' under Pillar One”, public consultation document.

OECD (2018a), OECD Economic Surveys: Ireland 2018, OECD Publishing, Paris.

OECD (2018b), Good Jobs for All in a Changing World of Work: The OECD Jobs Strategy, OECD

Publishing, Paris.

OECD (2018c), The Future of Social Protection: What works for non-standard workers?, OECD

Publishing, Paris.

OECD (2018d), Rethinking antitrust tools for multi-sided platforms, OECD Publishing, Paris.

OECD (2018e), Leading the Digital Transformation from the Centre of Government, 37th Meeting of Senior Officials from Centres of Government, Session Notes, Dublin.

Sabadash, A. (2013), "ICT-induced technological progress and employment: a literature review", JRC Working Papers on Digital Economy, No. 2013/7.

Schwellnus, C., A. Geva, M. Pak, and R. Veiel (2019), "Gig economy platforms: Boon or bane?", OECD Economics Department Working Papers, No. 1550, OECD Publishing, Paris.

United Kingdom Department for Business, Energy \& Industrial Strategy (2017), Good work: the Taylor review of modern working practices, United Kingdom Department for Business, Energy \& Industrial Strategy, July.

United Kingdom Digital Competition Expert Panel (2019), Unlocking digital competition: Report of the Digital Competition Expert Panel, HM Treasury, London.

Vives, X. (2019), "Digital disruption in financial markets", note for OECD Competition Open Day, Paris. William Fry (2019), Mid-year M\&A Review 2018, William Fry Ireland, Dublin. 